\title{
WestVirginiaUniversity
}

THE RESEARCH REPOSITORY @ WVU

Graduate Theses, Dissertations, and Problem Reports

2007

\section{Essays on the economics of education}

Joshua C. Hall

West Virginia University

Follow this and additional works at: https://researchrepository.wvu.edu/etd

\section{Recommended Citation}

Hall, Joshua C., "Essays on the economics of education" (2007). Graduate Theses, Dissertations, and Problem Reports. 4306.

https://researchrepository.wvu.edu/etd/4306

This Dissertation is protected by copyright and/or related rights. It has been brought to you by the The Research Repository @ WVU with permission from the rights-holder(s). You are free to use this Dissertation in any way that is permitted by the copyright and related rights legislation that applies to your use. For other uses you must obtain permission from the rights-holder(s) directly, unless additional rights are indicated by a Creative Commons license in the record and/ or on the work itself. This Dissertation has been accepted for inclusion in WVU Graduate Theses, Dissertations, and Problem Reports collection by an authorized administrator of The Research Repository @ WVU.

For more information, please contact researchrepository@mail.wvu.edu. 


\title{
Essays on the Economics of Education
}

\author{
Joshua C. Hall \\ Dissertation Submitted to the \\ College of Business and Economics at \\ West Virginia University \\ Doctor of Philosophy \\ In \\ Economics \\ Russell S. Sobel, Ph.D., Chair \\ Peter J. Boettke, Ph.D. \\ Stratford M. Douglas, Ph.D. \\ Santiago M. Pinto, Ph.D. \\ Peter T. Leeson, Ph.D.
}

in partial fulfillment of the requirements for the degree of

Division of Economics and Finance

Morgantown, West Virginia

2007

Keywords: education, diversity, economic growth, interjurisdictional competition

Copyright 2007 Joshua C. Hall 


\title{
Abstract \\ Essays on the Economics of Education
}

\author{
Joshua C. Hall
}

The dissertation is a collection of essays examining three topics in the economics of education. The essays focus on the institutional structure of local and national education and the implications that demographics and institutional structure has on the productivity and financing of education. The first chapter introduces my essays by providing a brief overview of the economic study of education and highlights some of the major areas of research overlapping the topics covered in this dissertation. Chapter 2 looks at the impact of racial diversity on school performance. A measure of racial diversity is constructed for Ohio school districts to investigate the net effect of racial diversity on school district performance on statewide exams. The empirical results of this chapter suggest that racial diversity negatively affects school district performance. Chapter 3 considers the impact of interjurisdictional competition in the choice of a tax base. A spatial probit model is used on Ohio school district data to investigate two issues: 1) do school districts engage in 'yardstick competition' in their choice of an income tax; and 2) does the negative impact of interjurisdictional competition disappear once yardstick competition is taken into account. The empirical evidence shows that districts do engage in yardstick competition but that controlling for yardstick competition does not affect the significance of interjurisdictional competition. Chapter 4 examines the role of institutions in the return to human and physical capital. A theoretical model is developed where the effect of the change in capital on the rate of growth depends on the level of institutional quality. The empirical model is estimated using cross-country data, where measures of a country's institutions are interacted with their growth rates of physical and human capital. The empirical results suggest that the institutional environment is very important in translating human and physical capital accumulation into economic growth. Chapter 5 summarizes the key findings of previous chapters and discusses areas of future research. 


\section{Acknowledgements}

First and foremost I would like to thank my wife for the many sacrifices she has made over the years so that I could achieve my goals. Without her love, acceptance, and understanding, I would not be in a position to write these words. In addition, she gave birth to our two wonderful boys, Hamilton and Bennett, for which I am eternally grateful. A special thanks to my parents, Floyd and Gayle Hall, and my in-laws, Walt Lang and Greg and Junie Kerr for their help. Without your love and support (including many hours of watching Hamilton and Bennett), I might not be writing these words at all.

I would also like to thank my dissertation chair, Russell S. Sobel, for his time, attention, and advice the past three years. Having an advisor whose door is always open and who is receptive to any question (no matter how simple or inane) is incredibly valuable and for that I am extremely appreciative. In addition, for someone committed to individual liberty and economic freedom there have been fewer individuals more devoted to the cause. The following tribute, originally given by William F. Buckley at a dinner honoring a former professor of his at Yale, says it better than I ever could:

[He instilled confidence in] those of us who were convinced of the interrelationship of economic freedom and freedom [and allowed us to] go about our business with the unique confidence that comes from knowing that the champion of your ideas has met the challenger and is still champion.

I would be remiss if I did not thank Richard K. Vedder for his years of friendship and guidance. Had I not serendipitously taken his Intro to Macroeconomics years ago I would likely have never majored in economics, let alone pursue graduate studies in the field. I am also indebted to Rich's colleague and friend, Lowell E. Gallaway, for showing me how to take ideas seriously. It was watching Lowell methodically work through 
problems that first set me down the path of being a producer of scholarship rather than a consumer.

I am grateful to Robert A. Lawson for three reasons. First, he is a good friend and a fellow connoisseur of single malts. Second, he introduced me to vintage base ball. Third, he encouraged me to come to study at West Virginia.

I would also like to thank the remaining members of my dissertation committee for all their help inside and outside the classroom and in the dissertation writing process. I am grateful for Peter J. Boettke for taking the time to speak to young scholars. A brief fifteen minute conversation with him after a talk he gave ten years ago started me thinking about the academy as a career. Stratford M. Douglas embodies everything that I have come to appreciate about the economics department at West Virginia. He is a collegial colleague, a devoted teacher, and an all-around interesting person. Together with Russ, Peter T. Leeson showed me what it means to be a productive scholar and his example serves as unattainable inspiration for my efforts. Santiago M. Pinto is the best teacher I have ever had, period. I cannot thank him enough for his time helping me to 'shake off the rust' at the beginning of that first year and for being a good sounding board for my ideas.

Finally, I would like to acknowledge the financial support of the economics department at West Virginia, the Institute for Humane Studies Dan Searle Fellowship, and the H.B. Earhart Foundation. Each of these organizations helped support my studies and research at various points during my studies. Without their help, I could not have written, presented, and published as many papers as I have the past three years, and for that I am eternally grateful. 


\section{Table of Contents}

\section{Chapter 1}

\section{Introduction}

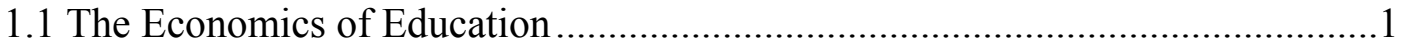

1.2 Dissertation Research Agenda ...............................................................4

\section{Chapter 2}

Racial Diversity and School Performance

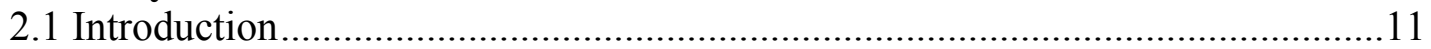

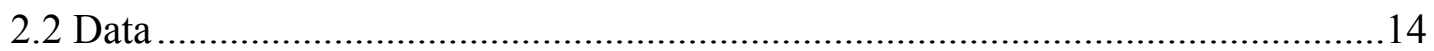

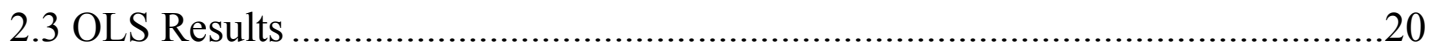

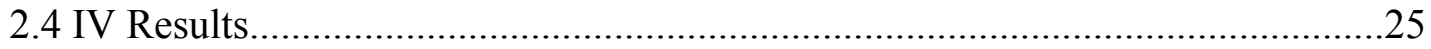

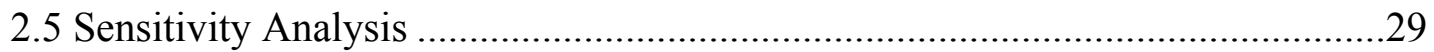

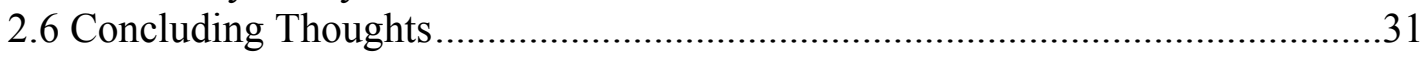

\section{Chapter 3}

Does Tiebout Move or Vote?

Fiscal Competition, Yardstick Competition and Income Tax Use

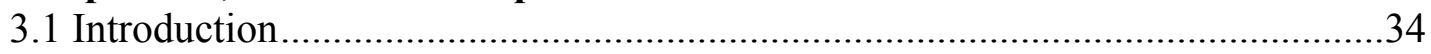

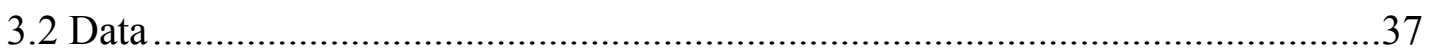

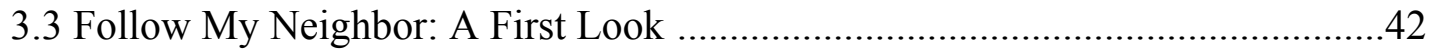

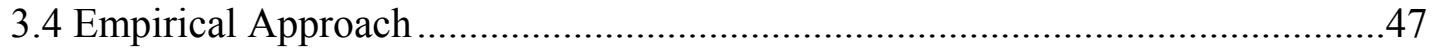

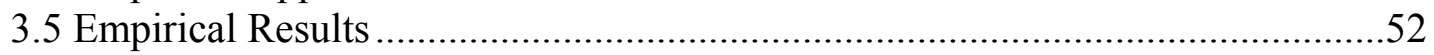

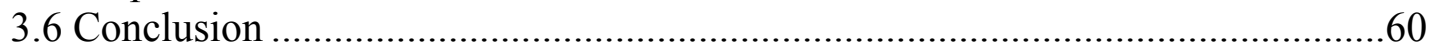

\section{Chapter 4}

\section{Institutions, Capital, and Growth}

4.1 Introduction .62

4.2 Institutions, Capital, and Growth of Output per Worker ..................................66

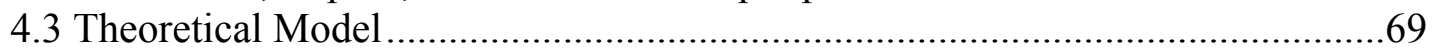

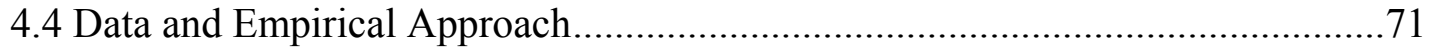

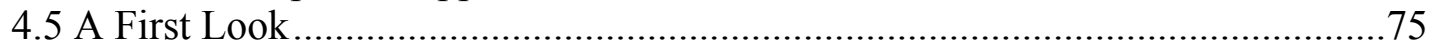

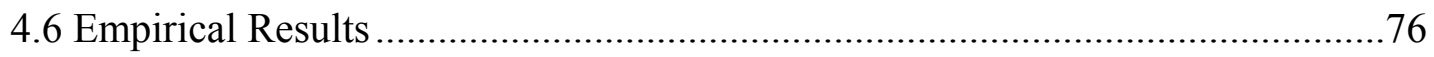

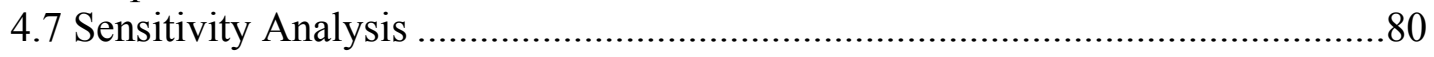

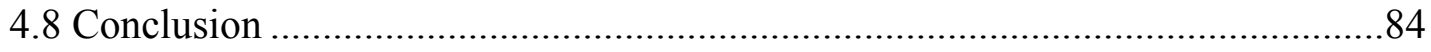

\section{Chapter 5}

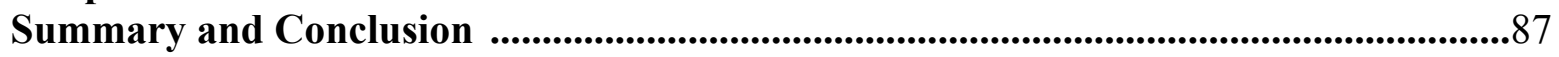

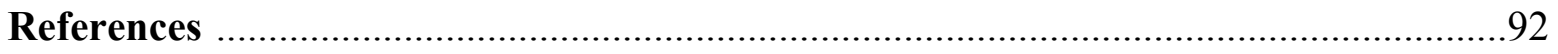

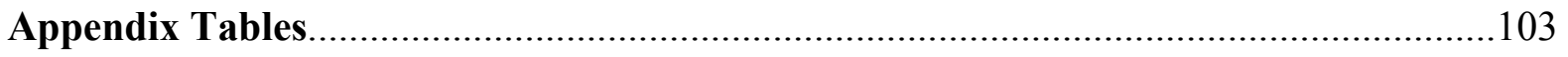

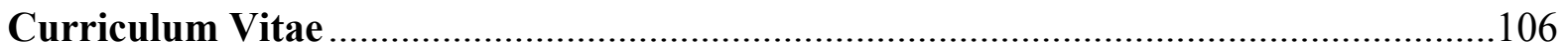




\section{List of Tables}

Table 2.1 Variable Definitions and Summary Statistics ..............................................19

Table 2.2 Racial Diversity and District Math Scores: OLS Estimates ..............................22

Table 2.3 Racial Diversity and District Math Scores: IV Estimates..................................28

Table 2.4 Racial Diversity and District Math Scores: Sensitivity Analysis ........................30

Table 3.1 Summary Statistics for Ohio School Districts, 1996-97 School Year.................42

Table 3.2 Fiscal Competition and Tax Instrument Choice: Model Comparisons.................54

Table 3.3 Fiscal Competition and Tax Instrument Choice: Robustness Checks .................59

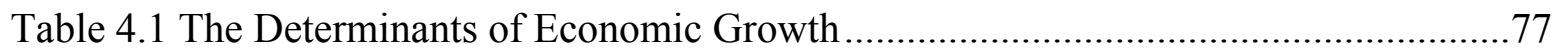

Table 4.2 The Determinants of Economic Growth: Alternative Measures of Education......82

Table 4.3 The Determinants of Economic Growth: Alternative Measures of Institutions ....84

Appendix Table 1 Racial Diversity and Non-Math Test Scores.......................................103

Appendix Table 2 Marginal Effects Times Standard Deviations .....................................104

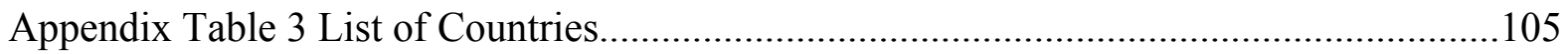




\section{List of Figures}

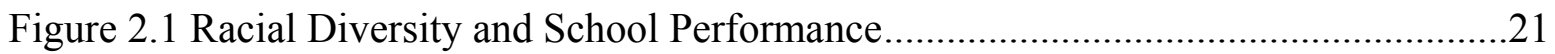

Figure 3.1 Ohio School Districts with an Income Tax, 1997 ...............................................43

Figure 3.2 Income Tax Use in Mercer County, 1989-1997 ………………………...........44

Figure 3.3 Income Tax Use in Darke County, 1989-1997 .................................................45

Figure 3.4 Income Tax Use in Miami County, 1989-1997 .................................................45

Figure 3.5 Income Tax Use in Putnam County, 1989-1997 ...............................................46

Figure 4.1 Marginal Effect of Capital on Output per Worker: Conventional View ..............67

Figure 4.2 Marginal Effect of Capital on Output per Worker: Institutional View ................69

Figure 4.3 The Stratification of Returns to Schooling by Risk of Expropriation ..................76

Figure 4.4 The Marginal Effect of Capital on Growth: An Estimate ...................................79 


\section{Chapter 1 \\ Introduction}

\subsection{The Economics of Education}

The emergence of the economics of education as an autonomous field in of inquiry within economics did not begin until the early 1960s (Texeira 2000) when Theodore Schultz (1961) made human capital the topic of his 1960 presidential address to the American Economic Association. Human capital is the idea that the schooling and skills that individuals acquire are not purely consumption goods but instead are assets that yield income and other outputs over time. While the concept of human capital had been around since the time of Adam Smith ([1776] 1998), the term and its study first came into popular use beginning with Schultz's presidential address. Historian of economic thought Mark Blaug (1972) credits Schultz with initiating the 'human investment revolution in economic thought' with his presidential address, subsequent articles, and influence over graduate students at the University of Chicago. In terms of overall importance to study of what we know consider the field of the economics of education, however, no one individual has had more influence than Gary Becker.

His first article (1962) and book (1964) on human capital formed the theoretical and empirical approach to human capital that we employ today. In his post-Nobel tribute to Becker, Sherwin Rosen (1993: 26) says that "no one other than Becker has developed these ideas into such a coherent and fruitful theory." What separated Becker and others post-1960 economists working on human capital issues from the previous literature on the economics of education was a theoretical framework that allowed education to be 
both an investment and consumption good. Prior to 1960, the conventional view in economics was that individuals attended school primarily because it was compulsory. Any additional education beyond the age of compulsion was generally treated as consumption (Blaug 1976). According to Rosen (1993), Becker's theoretical and empirical contributions forced the discipline to take a closer look at education, which in turn led to tremendous improvements in our understanding of earnings in labor markets (Psacharapolous 1985), the organization of the firm (Williamson 1985) and economic growth (Romer 1986).

The 1960s and 1970s saw tremendous gains being made in human capital theory. At the same time, began to focus on the institutional structure of education and its impact on school outcomes. Unlike human capital theory, which primarily focused on explaining wages or labor earnings, this new line of inquiry focused attention on how various inputs into the education process translated into student outcomes (Hanushek 1996). Researchers began to use so-called 'education production functions' to look at a variety of factors thought to influence school productivity, typically measured by standardized test scores or graduation rates. A prominent strain of this literature focuses on the role that school resources play in school performance (Hanushek 1997). Another line of inquiry focuses on the interaction between the structure of schooling in the United States and its effect on school financing and outcomes. It is in this general area that my dissertation focuses.

In his seminal paper, Tiebout (1956) considered households working in a geographic area choosing among a market of local public good producers. In the extreme, households would sort themselves into homogenous communities based on their 
preferences over the local public good being provided such as education. If every household had the same preference, there would only need to be one jurisdiction. As the number of different household preferences for education increase, the number of jurisdictions should increase proportionally to achieve perfect sorting by education preference. In the real world, however, economies of scale (Kenny and Schmidt 1994), geographic barriers (Hoxby 2000a), and legal barriers (Fischel 2007) limit the number of school districts to a level below what would allow perfect sorting. As a result, the educational preferences of many residents might vary considerably from that of the median voter. This preference fractionalization can lead to reduced political oversight and governance by voters (Romer, Rosenthal, and Munley 1992) or reduced spending on public schools (Alesina, Baqir, and Easterly 1999). Chapter 2 extends this literature by considering the possibility that preference fractionalization by race leads not only to lower spending but also to a decline in school quality.

Competition among local school districts has been found to lead to higher test scores (Staley and Blair 1995; Hoxby 2000a). These general findings have recently been called into question on empirical grounds (Rothstein 2005; Brasington 2007). Brasington (2007) argues that failure to account for spatial dependence has led to an overstatement of the effectiveness of interjurisdictional competition. The interjurisdictional competition literature has been extended to the research on local government choice of tax instruments. School districts might prefer to diversify their tax base by adopting an income tax but choose not to do so, given that high-income residents might flee to nearby school districts. This issue is addressed further in Chapter 3 using spatial econometrics to address spatial dependence among school districts. 
Institutions - the humanly devised constraints that structure political and economic interaction (North 1991) - have long been understood to be important to economic development. Development economists have only recently begun to understand the primacy of institutions for development policy (Rodrik, Subramanian, and Trebbi 2004). Despite the recent recognition of the importance of institutions, traditional growth theory and the development policy it engenders still tends to focus on physical and human capital accumulation. In bad institutional environments, however, investment in physical and human capital often has a lower social return because the increase in capital is often directed towards zero or negative-sum activities. Actions that are privately optimal in bad institutional environments (such as rent-seeking), reduce or eliminate the benefits accruing to society at large from additions to the human and physical capital stocks. Instead of increasing economic growth, spending scarce resources on physical and human capital in countries with poor institutional environments can actually lower output per worker instead of increasing it. The role that institutional quality plays in the return on physical and human capital accumulation is investigated in Chapter 4.

\subsection{Dissertation Research Agenda}

There are three research essays in this dissertation that examine the effect of institutions on educational outcomes and financing. The first essay, Chapter 2, looks at the impact of racial diversity on school district performance. Chapter 3 addresses the issue of fiscal competition in the choice among of an income tax and Chapter 4 examines the effectiveness of investment in human and physical capital in different institutional environments. Chapter 5 concludes with an overview of my findings. 
In Chapter 2, I examine the empirical issue of whether or not racial diversity is good for school district performance. The impact of racial diversity on school performance has been an important policy issue for a long time, with social scientists attempting to measure the influence of racial diversity on the academic achievement of African-Americans since at least the 1954 U.S. Supreme Court decision in Brown v. Board of Education. In recent years, the economics literature has turned its attention back to the issue of race as many popular school reforms such as ability tracking and charter schools have led the racial composition of schools to become more homogeneous. As a result of this change, a body of research has developed that looks at the effect of race on school performance.

In the literature there are two possible channels through which racial diversity could influence school district performance. The first perspective - the racial peer effect channel - views integration as having positive benefits flowing from children of different racial backgrounds being exposed to one another. Following Brown v. Board of Education, this literature primarily focused on the impact of increased racial diversity on African-American students. A second channel through which racial diversity could affect school performance is through voting. Different racial groups could have systematically different preferences over how schools should be operated and these different preferences could manifest themselves in policies that are not conducive to the efficient operation of schools. The basic intuition behind the models in this area is that in diverse communities disagreement over the 'right' education policy will lead individuals with preferences drastically different from the median voter to undertake actions that reduce school 
quality. For example, disgruntled voters could vote against new spending on schools in order to finance private consumption.

These channels are both theoretically important reasons why racial diversity might affect academic performance; however, these channels suggest different directional effects of increasing racial diversity. The voting channel suggests that increasing racial diversity would lead to a decline in school quality holding other factors constant while the peer effect channel suggests that increasing diversity raises school quality. Furthermore, the racial peer effect literature focuses almost exclusively on the benefits to African-American children. If non-African-American students do worse as diversity increases, the overall effect of increased diversity could be negative. In this chapter I focus on the net effect of racial diversity on school performance. Using data on Ohio school districts I find a consistently negative relationship between racial diversity and school quality as measured by district-level test scores using a variety of different specifications and robustness checks.

Chapter 3 considers the effect of interjurisdictional competition on the use of an income tax to finance schools. Economic theory would predict that when given the opportunity to do so, local governments would diversify across as many revenue sources as possible. Ohio is one of two states that allow school districts to choose among tax instruments. Public choice theory would suggest that local policymakers have an incentive to diversify their tax base in order to minimize the risk associated with overreliance on any one particular tax base. Even if politicians did not value diversification for political reasons, standard public finance principles (the 'three-legged stool' of income, property, and sales taxes) argue in favor of diversification across all available 
bases. However when given the chance, many local governments do not diversify their tax base. Why?

One argument put forth in the literature is that is that tax bases differ in their mobility characteristics. The property tax base is primarily fixed in the short run while the income tax base is fairly mobile. Local governments are unwilling to adopt an income tax only to see mobile high-income households move to a nearby district. This theory predicts that as the cost of mobility increases (fewer school districts in a given geographic area) more school districts will use the income tax. Spry (2005) tested this theory using data on Ohio school districts and found that the number of districts within 10 miles depresses income tax adoption.

In my paper, I challenge this finding on theoretical and empirical grounds. Caplan (2001) argues you cannot escape taxation by moving because of capitalization. Since the costs and benefits of higher taxes are reflected in home prices, high-income taxpayers cannot escape school district income taxes. When they go to sell their home they will get less for the home because of the higher tax-to-benefit ratio. Thus 'voting with your feet' is unlikely to limit the use of income taxes. In addition, the spatial pattern of income tax adoption identified by Spry (2005) as being consistent with interjurisdictional competition depressing income tax usage is also consistent with other spatial theories, such as yardstick competition, or non-spatial reasons such as tax exportation.

In addition, Spry (2005) employs traditional probit when estimating the probability of a school district adopting an income tax. This approach does not take into account spatial spillovers and thus estimated parameters are likely to be biased, inconsistent, and inefficient (Anselin 1988). Previous empirical work has found that the 
effects of interjurisdictional competition often disappear once spatial effects are taken into account (Brasington 2007), suggesting that the previous literature might be contaminated by spatially omitted variable bias. This chapter addresses spatially omitted variable bias and tests for yardstick competition using spatial econometric techniques. The results show that interjurisdictional competition does not depress the use of an income tax once spatial dependence is taken into account. In addition, there is evidence of positive yardstick competition between neighboring districts. The primary factor found to depress income tax usage is the amount of business property within the school district, suggesting that school district residents would rather attempt to export a portion of their tax burden onto non-resident property owners rather than levy an income tax for which they would bear the entire burden.

Chapter 4 examines the return to increases in human and physical capital across nations. Early research showing a relationship between education and economic growth led development economists to focus on human capital in addition to physical capital as primary inputs into stimulating growth in developing countries (Coyne and Boettke 2006). The World Bank, for example, encouraged high levels of government investment in primary schooling in an attempt to increase human capital levels, leading to a tremendous expansion of schooling in nearly all developing countries (Easterly 2001). Unfortunately, this increase in education has not uniformly led to increased economic growth. Some countries, like Taiwan, greatly increased education levels and did well economically while other countries such as Zambia stagnated. What makes investment in human (and physical) capital effective in some countries and not in others? 
In this essay I address this question by considering the institutional context of investment in human and physical capital. Societal payoffs to investment in human capital are largely dependent on the institutional context in which those investments occur. Consider two countries with equal levels and productivity of human capital investment but vastly different institutional quality. In the country with good institutions such as the rule of law and minimal government intervention into the economy, additional human capital will generally be employed towards positive-sum activities. It is the generation and exploitation of these positive-sum entrepreneurial opportunities that results in economic progress. Conversely, in the country with poor economic institutions, human capital is more likely to be employed towards zero-sum or negative-sum economic activities. While the educated might benefit personally from their additional education, the exploitation of the mostly negative-sum opportunities available to them in a bad institutional environment will result in economic regress.

A theoretical model is developed that allows the effect of changes in output per worker to vary along with institutional quality. I then test this model empirically using data on 96 countries from 1980-2000 and find that the effect of changes in human and physical capital varies considerably with the level of institutional quality. The results indicate that for countries with the lowest quality institutions the return to investments in human and physical capital per worker are negative and that there exists some 'breakeven' point of institutional quality where returns become positive. The break-even point for physical capital is lower than for human capital, suggesting that countries with institutional quality between the two break-even points focus on physical capital instead of human capital. More importantly, however, these results focus attention towards 
institutional reform as the key to economic progress so that all countries move above the break-even point for both forms of capital. 


\section{Chapter 2 Racial Diversity and School Performance}

\subsection{Introduction}

The impact of racial diversity on school performance has long been a concern of parents and policymakers. The influence of racial diversity on the academic achievement of African-American students was at the heart of the 1954 U.S. Supreme Court decision in Brown v. Board of Education (Armor 1995). 'White flight', where white families move to segregated communities or enroll their children in private schools, is another historical manifestation of this concern (Fairlie and Resch 2002). More recently, the public policy debate surrounding ability tracking, charter schooling, open enrollment, and school vouchers has been rife with concern over how these policies will impact school racial composition and resulting academic outcomes (Greene 1999; Renzulli and Evans 2004). As a result of this concern, a body of research has developed that looks at the effect of racial 'peer effects' on school performance.

Following the Brown v. Board of Education decision, early social science research focused primarily on the harmful effects of racial isolation on the academic performance of African-Americans. Two influential reports were Coleman et al. (1966) and the U.S. Commission on Civil Rights (1967), which found that the racial isolation experienced by African-American students in segregated schools lowered their academic achievement. Jenks et al. (1972) finds that desegregation improves black children's

school performance by two to three percent. Guryan (2004) estimates that half of the 
decline in black dropout rates during the 1970s occurred because of desegregation. Hoxby (2000b) finds that black third graders perform substantially worse when surrounded by other black students than in classes that are primarily white. Hanushek, Kain, and Rivkin (2004) isolate the peer composition of racial diversity and find similar results, namely that having a higher percentage of black classmates lowers black academic achievement. Thus positive racial peer effects are the conventional channel through which racial diversity is thought to affect school performance.

Another channel through which racial diversity could affect school performance is through the ballot box. There is a growing body of research in international development demonstrating that racial, ethnic, and linguistic diversity has a negative effect on the individuals' willingness to spend on publicly-provided goods like roads and schools. ${ }^{1}$ Alesina, Baqir and Easterly (1999) develop a simple theoretical model showing how diverse preferences over a publicly-provided good can lead to reduced spending. The basic intuition behind their model is that diverse communities will have lower public spending because individuals with preferences vastly different from the median voter will prefer to keep taxes low and spend their money on private consumption.

Alesina, Baqir and Easterly (1999) argue that racial groups often have very different views on public policies such as bilingual education (see, for example, Leal and Hess (2000)). In their model, the groups whose preferences are not reflected in school policy vote for lower spending rather than financially support policies with which they disagree. Alesina, Baqir and Easterly (1999) provide some empirical confirmation of

\footnotetext{
${ }^{1}$ The economic literature primarily uses the term 'fractionalization' when discussing diversity. In the interest of clarity, here I will exclusively use the phrase diversity, even when discussing papers on racial and ethno-linguistic fractionalization. In most studies, ethno-linguistic diversity is defined as the probability that two individuals randomly drawn from a jurisdiction are from different ethno-linguistic groups. See Alesina et al. (2003) for an overview of this research.
} 
their theoretical model by showing empirically that cities and counties with high levels of racial diversity have lower spending on schools, roads, and other publicly-provided goods. If spending less on schools leads to lower output, their work suggests a different channel through which racial diversity could lead to lower school performance. ${ }^{2}$

Both the peer effect channel and the voting channel are important reasons why racial diversity might affect school performance. However, these channels are in conflict since the peer effect channel generally supports the view that integration improves school performance, while the voting channel proposes that racial diversity lowers it. Furthermore, the literature on racial 'peer effects' is almost exclusively focused on the effect of racial concentration on the academic success of black students, not on the net effect of diversity. ${ }^{3}$ If other students do worse in integrated classrooms, the overall effect of racial diversity on education outcomes could be negative. Thus when the racial peer effect literature shows that integration increases test scores for black students, this tells us little about how racial diversity impacts overall school performance. ${ }^{4}$

In this paper, I fill that gap by focusing on the net effect of racial diversity on school performance. Using data on Ohio school districts, I find a consistently negative relationship between racial diversity and student performance at the district level. I begin first by describing my data: how the index of racial diversity is constructed, the measure

\footnotetext{
${ }^{2}$ In the international context, the link between spending and school performance is extremely difficult to test given the lack of consistent test score data. Easterly and Levine (1999) find, however, that ethno-linguistic diversity is negatively correlated with the years of schooling people obtain.

${ }^{3}$ For example, both Hoxby (2000b) and Hanushek, Kain, and Rivkin (2004) find that blacks, Hispanics, and whites all do worse as the percentage of their classmates that are black increases. This clearly suggests that there might be a trade-off between improved black achievement and reduced white or Hispanic achievement, although they do not address the net effect.

${ }^{4}$ One exception is Angrist and Lang (2004) who find modest positive peer effects for minority third graders from integration with no negative effects for white students.
} 
of school district performance, and the independent variables used in the analysis. Then I present the empirical results using both OLS and IV estimation, demonstrating that the negative relationship between racial diversity and school performance is healthy to a variety of different specifications and robustness checks. Finally, I conclude with a discussion of the policy and research implications of my results.

\subsection{Data}

I construct my data set from two sources. The first source is the Ohio Department of Education's 'Cupp Report." The Cupp Report summarizes all of the data collected by the Ohio Department of Education on individual local school districts. The report contains data on student outcomes, student demographics, teacher demographics, district spending, revenue, property valuation, and tax information. The second data source is the U.S. Census Bureau’s special 'Census 2000 School District Tabulation.’ From the 2000 Census report I obtained racial data on school district residents, the mean household income within each school district, linguistic diversity, adult education levels, and private school enrollment by school district. All variables from the 'Census 2000 School District Tabulation' and the 'Cupp Report' are for the 1999-2000 school term. ${ }^{6}$

\footnotetext{
${ }^{5}$ The Cupp Report was renamed in 2006 to 'Finance and Other Data.' The most recent version of the publication formerly known as the Cupp Report can be found online at $<$ http://www.ode.state.oh.us $>$.

${ }^{6}$ The Cupp Report is not kept historically and is generally published with a two-year lag. Thus the Cupp Report data for the 1999-2000 school year was collected from the Ohio Department of Education's website in early 2002.
} 
Focusing within one state can be problematic if there is insufficient variation among school districts within the state. ${ }^{7}$ Lack of diversity or a few significant outliers can lead to imprecise or statistically biased results. This is not a problem with Ohio, which is a large and geographically diverse state containing 612 local school districts. Ohio has several large metropolitan school districts with over thirty thousand students and numerous small rural districts with fewer than one thousand students. While over a quarter of a million students are enrolled in Ohio's five largest city school districts, over eighty-five percent of students are enrolled in the remaining suburban, exurban, small city, and rural school districts. After removing five small rural school districts due to incomplete data, the final sample contains 607 school districts. ${ }^{8}$

My variable of primary interest is the degree of racial diversity within a school district. Intuitively, the racial diversity index measures the probability that two school district residents drawn randomly will be of different races. The degree of racial diversity within a school district is calculated using the following formula:

$$
\text { Racial Diversity }=1-\sum_{i}\left(\text { Race }_{i}\right)^{2}
$$

where Race $_{i}$ is the percentage of a school district's population that identifies itself as being of that particular race. The racial classifications I use are those presented by the

\footnotetext{
${ }^{7}$ Many states, for example, have only county-level school districts. The observed level of racial integration across school districts in these states may have less to do with preferences for integration and more to do with the lack of interjurisdictional competition. Clotfelter (1999), for example, finds less across district segregation but more within district segregation in the South, where county-level school districts are the norm.

${ }^{8}$ Ohio has four 'island districts' that serve children living year-round on resort islands in Lake Erie. The small size of these districts means that often times an entire grade level is comprised of only one student. For this reason, the Ohio Department of Education censors data on these school districts due to privacy concerns. College Corner Local School District was removed because it is a combined Ohio/Indiana school district and thus represents a blending of both states financial and property tax systems.
} 
U.S. Census Bureau to individuals on the census form. There are seven racial classifications in the 2000 Census School District Tabulation: White, Black, Asian and Pacific Islander, American Indian, Native Hawaiian, Some Other Race Alone, and Two or More Races. A completely racially-homogenous school district would have an ethnic diversity score of zero. A school district whose population was equally split between two races would have a racial diversity score of $0.5 .^{9}$ A district where each racial classification was one-seventh of the population would have a score of 0.857 .

Admittedly, these racial classifications do not directly correspond to individuals notions of race. There is, for example, no category for 'Hispanic.' The Census Bureau does not ask individuals if they are 'Hispanic' in the context of asking about an individual's race. That information is obtained from questions on place of origin. Alesina, Baqir and Easterly (1999) provide some evidence that the category 'Some Other Race Alone' is, for all intents and purposes, equivalent to Hispanic. ${ }^{10}$ In addition, the treatment of multiracial individuals as having a separate racial identity is problematic. Individuals identifying themselves as multiracial for the purposes of the Census probably do not consider 'multiracial' interests or have a 'multiracial' perspective when at the ballot box. Multiracial individuals are likely to have preferences that are closely aligned to another racial classification because of cultural or identity reasons. Given the impossibility of

\footnotetext{
${ }^{9}\left(0.5^{\wedge} 2\right)+\left(0.5^{\wedge} 2\right)=0.5$.

${ }^{10}$ Alesina, Baqir and Easterly (1999) argue that their racial classification of 'Other' is essentially Hispanic, given that the correlation between the two Census Variables is 90 percent. They do not include a separate category for multiracial individuals, however, so it is not clear if their 'Other' classification is identical to the classification 'Some Other Race Alone' or if it also includes multiracial individuals. The high correlation between Hispanic and 'Other' suggests that they did not include multiracial individuals with 'Other.'
} 
knowing the proper allocation of multiracial individuals among the basic racial classifications, I keep the category Two or More Races separate. ${ }^{11}$

District-level racial diversity has considerable variability in Ohio. The most racially-homogenous district in the state is Jennings Local School District in Putnam County, a primarily rural area located in Northwest Ohio. During the 2000 Census, 1905 of the district's residents where white and four of the districts residents were Asian, which gave the district a racial diversity score of 0.005 . The most racially-fractionalized school district in the state is its largest, the Cleveland Municipal School District, with a score of 0.567 . The average school district in the state has a racial diversity score of 0.102 and the standard deviation of this variable is 0.109 .

The presence of a large urban school district, such as Cleveland, as the most racially-diverse school district in the state could lead to the conclusion that racial diversity is a proxy for large, predominantly poor, urban school districts. A look at racially-diverse school districts reveals that this might not be the case. While large urban school districts such as Akron, Cleveland, Cincinnati, and Columbus, Toledo, and Youngstown are among the most racially-diverse school districts in the state, they are sprinkled around middle-to high-income suburban districts such as Shaker Heights School District in Cleveland. Shaker Heights High School was recently cited by the Wall Street Journal as being one of the top feeder schools to elite colleges (Bernstein 2004) and its racial diversity attracts families to the area with a preference for integration (Brand-Williams 2002). The simple correlation between racial diversity and median

\footnotetext{
${ }^{11}$ Exclusion of the category Two or More Races from the calculation of the racial diversity variable does not change the results presented in the paper.
} 
income per taxpayer in a school district is a negative 0.014 and is not statistically significant. $^{12}$

My primary dependent variable is the percentage of school district students passing the ninth grade math proficiency test during 1999-2000 school year. In Ohio, all students are required to take and pass five subject areas tests beginning in ninth grade in order to matriculate with a regular diploma. ${ }^{13}$ During the $1999-2000$ school year, tests were administered in math, reading, writing, citizenship, and science. In the interests of parsimony, I focus only on one test - the ninth grade math exam. ${ }^{14}$ The proficiency test scores from other ninth grade tests were used, however, to check the math test results against alternative definitions of school performance. The outcomes of a baseline regression employing the four other tests as a dependent variable are presented in Appendix Table $1 .{ }^{15}$

In addition to using racial diversity by school district to explain passage rates on statewide math exams, I include control variables representing family, community, and school influences that are conventional in the literature (Hanushek 2002). A full list of all of the variables is included in Table 2.1 along with descriptive statistics. Median income per tax return in the school district is included in the basic specification to account for

12 The null hypothesis of zero relationship cannot be rejected at the ten percent level of significance ( $\mathrm{z}$ critical value of 0.334 ).

${ }^{13}$ Ohio's testing system has subsequently been revamped and the test required for graduation is a new tenth grade proficiency exam.

${ }^{14}$ The math test was chosen for two reasons. First, it is the most objective of the five exams. Second, historically it is the most difficult of the tests. Fisher (2001) notes that of the 2,678 students unable to graduate with their class because they failed one or more portions of the test, 1,888 failed the math portion.

${ }^{15}$ All of the measures of school performance are level scores instead of value-added scores. This could be problematic if value-added scores are a more appropriate measure of school performance. Brasington (1999) tests 37 different measures of school performance and finds that the measures of school performance that are capitalized into home prices are level scores not value-added scores, suggesting that use of level-scores is appropriate. 
family and background effects (Goldhaber and Brewer 1997). School-related inputs are district spending per pupil (Hedges and Greenwald 1996; Hanushek 1997), the studentto-teacher ratio (Krueger 2003), the average salary of classroom teachers, and the percentage of classroom teachers with up to four years of experience (Rivkin, Hanushek, and Kain 2005).

Table 2.1

Variable Definitions and Summary Statis tics

\begin{tabular}{llc}
\hline \multicolumn{1}{c}{ Variable } & \multicolumn{1}{c}{ Definitions } & Mean (S.D.) \\
\hline Racial Diversity 2000 & See text for definition & $0.101(0.109)$ \\
Racial Diversity 1990 & See text for definition & $0.077(0.096)$ \\
Linguistic Diversity & See text for definition & $0.128(0.064)$ \\
Income Diversity & Mean household income / median household income & $1.214(0.104)$ \\
Black & \% of Black district residents & $0.037(0.091)$ \\
Math & \% of district students passing 9th grade math test & $0.769(0.117)$ \\
Science & \% of district students passing 9th grade science test & $0.827(0.096)$ \\
Reading & \% of district students passing 9th grade reading test & $0.928(0.054)$ \\
Citizenship & \% of district students passing 9th grade citizenship test & $0.857(0.081)$ \\
Writing & \% of district students passing 9th grade writing test & $0.936(0.050)$ \\
Graduation Rate & \% of Fall 1996 9th grade class graduating in 2000 & $0.863(0.090)$ \\
Spending Per Pupil & School district spending per pupil & $\$ 6,662(1,142)$ \\
Attendance & \% of district students in attendance on an average day & $0.948(0.013)$ \\
Teacher Inexperience & \% of teachers with 4 or fewer years of experience & $0.227(0.080)$ \\
Pupil/Teacher Ratio & Enrollment / classroom teachers & $18.28(2.045)$ \\
Average Teacher Salary & Average salary of classroom teachers in the district & $\$ 39,320(4,908)$ \\
Income & Median income per tax return filed within district & $\$ 30,571(6,411)$ \\
College & \% of district residents 25 \& older with at least a BA & $0.172(0.122)$ \\
Free or Reduced Lunch & \% of students eligible for free or reduced price lunch & $0.212(0.143)$ \\
District Size & Number of students enrolled in the district & $3,008(5,274)$ \\
Density & District population / district square mileage & $778(2,405)$ \\
Private School & \% of 5-17 year-olds attending private schools & $0.102(0.075)$ \\
\hline Note: All & &
\end{tabular}

Note: All observations are for the 1999-2000 school year unless otherwise noted. 
Population density has been found to influence student outcomes although the exact reason is unclear (Driscoll, Halcoussis, and Svorny 2003). Driscoll, Halcoussis, and Svorny (2003) hypothesize that there is a negative relationship between population density and school performance because it is more difficult to educate in urban schools. District size is included to account for possible diseconomies of scale with respect to school district size. A large number of studies find a negative relationship between school district size and student performance (Fox 1981; Niskanen 1998; Driscoll, Halcoussis, and Svorny 2003). ${ }^{16}$ Finally, attendance is included to account for the fact that school districts with higher attendance rates have higher test scores (Lamdin 1996).

\subsection{OLS Results}

Figure 2.1 depicts a simple negatively-sloped regression line fitted between district passage rates on the ninth grade math test and racial diversity. In order to test this observed relationship econometrically, I estimate the following model using Ordinary Least Squares (OLS):

$$
\text { SCHOOLPERFORMANCE }_{i}=\beta_{0}+\beta_{1} \text { RACIALDIVERSITY }_{i}+\sum_{x=1}^{X} B_{x} Z_{x, i}+\varepsilon
$$

where $\mathrm{SCHOOLPERFORMANCE}_{i}$ is the passage rate on the ninth grade math proficiency test in district $i$ for the 1999-2000 school year; RACIALDIVERSITY ${ }_{\mathrm{i}}$ is the degree to which the residents of school district $i$ are divided among different racial categories; and $\mathrm{Z}_{\mathrm{i}}$ is a vector of control variables representing school, community, and

\footnotetext{
${ }^{16}$ For a recent contrary view, see Heinesen (2005).
} 
family influences for each district. $\beta_{1}$ is the coefficient of primary interest as it measures the impact of racial diversity on the measure of school performance.

Figure 2.1

Racial Diversity and School Performance

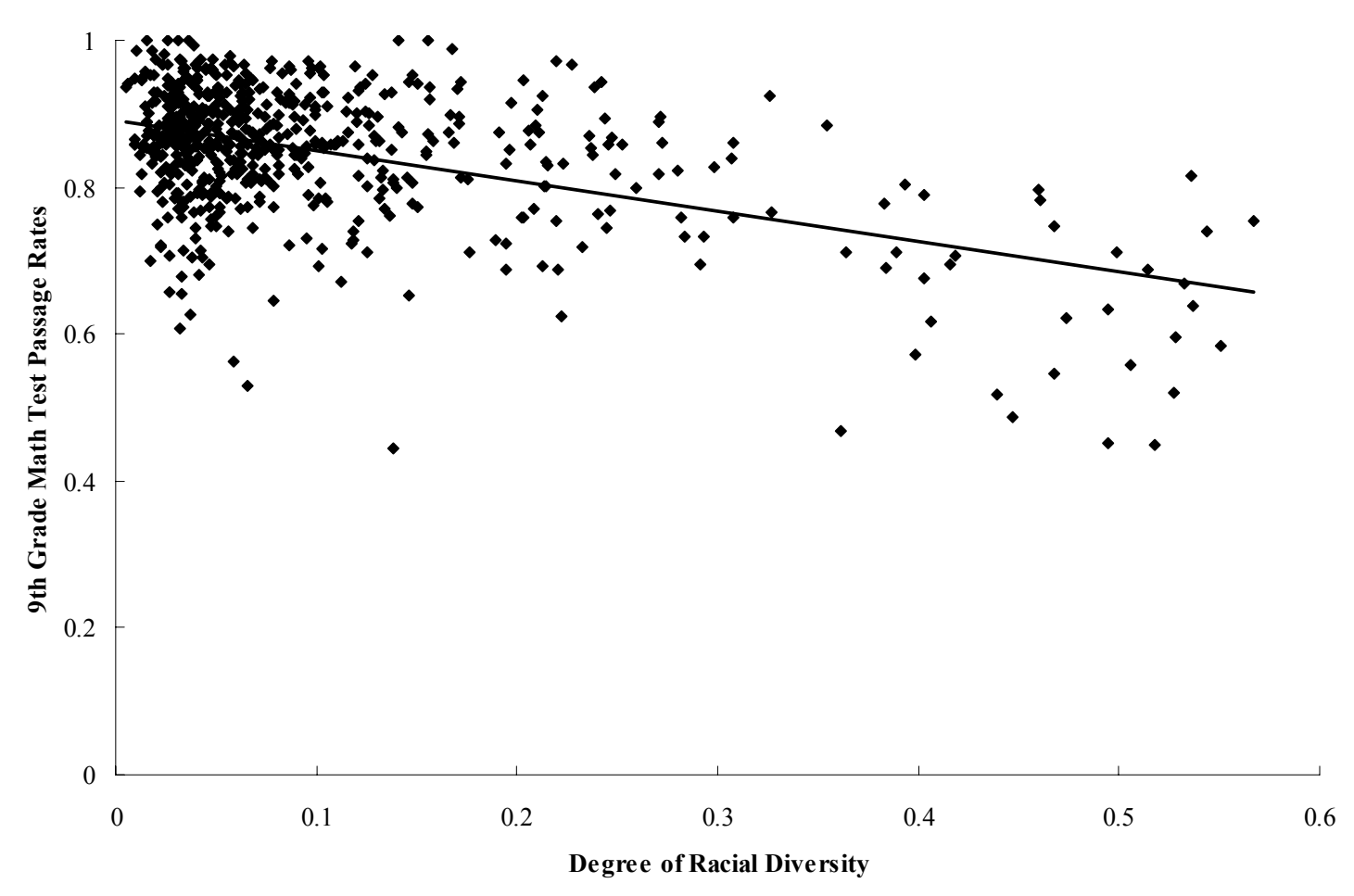

The OLS regression results are presented in Table 2.2, which provide preliminary evidence that racial diversity is negatively related to school performance. A baseline regression is presented in Column 1 of Table 2.2. This basic model does a good job, explaining nearly 60 percent of the variation in passage rates on the ninth grade math proficiency test across school districts. The key variable of interest, racial diversity, is negative and statistically significant at the one percent level. The racial diversity variable theoretically varies from complete homogeneity at zero to perfect heterogeneity at one, making interpretation of the coefficient on racial diversity fairly simple. 
Table 2.2

\section{Racial Diversity and Dis trict Math Scores: OLS Estimates}

\begin{tabular}{|c|c|c|c|}
\hline & 1 & 2 & 3 \\
\hline Constant & $\begin{array}{l}-2.65 * * * \\
(6.13)\end{array}$ & $\begin{array}{l}-1.76^{* * *} \\
(3.96)\end{array}$ & $\begin{array}{l}-1.75 * * * \\
(3.89)\end{array}$ \\
\hline Racial Diversity 2000 & $\begin{array}{c}-0.2805 * * * \\
(5.85)\end{array}$ & $\begin{array}{c}-0.2431 * * * \\
(5.12)\end{array}$ & $\begin{array}{c}-0.2423 * * * \\
(5.12)\end{array}$ \\
\hline Expenditure Per Pupil & $\begin{array}{c}-0.0085 * * \\
(2.07)\end{array}$ & $\begin{array}{r}-0.0052 \\
(1.24)\end{array}$ & $\begin{array}{r}-0.0049 \\
(1.13)\end{array}$ \\
\hline Income & $\begin{array}{l}0.0062 * * * \\
(8.11)\end{array}$ & $\begin{array}{r}0.0005 \\
(0.49)\end{array}$ & $\begin{array}{r}0.0004 \\
(0.40)\end{array}$ \\
\hline Attendance & $\begin{array}{l}3.5363 * * * \\
(7.82)\end{array}$ & $\begin{array}{l}2.7932 * * * \\
(6.21)\end{array}$ & $\begin{array}{l}2.8042 * * * \\
(6.21)\end{array}$ \\
\hline Pupil/Teacher Ratio & $\begin{array}{c}-0.0054 * * * \\
(2.60)\end{array}$ & $\begin{array}{c}-0.0038 * \\
(1.93)\end{array}$ & $\begin{array}{c}-0.0038 * \\
(1.91)\end{array}$ \\
\hline Average Teacher Salary & $\begin{array}{l}0.0023 * * \\
(2.15)\end{array}$ & $\begin{array}{r}0.0007 \\
(0.64)\end{array}$ & $\begin{array}{r}0.0007 \\
(0.66)\end{array}$ \\
\hline Teacher Inexperience & $\begin{array}{c}-0.1178 * * \\
(2.49)\end{array}$ & $\begin{array}{c}-0.1099 * * \\
(2.39)\end{array}$ & $\begin{array}{c}-0.1095 * * \\
(2.37)\end{array}$ \\
\hline Density & $\begin{array}{r}-0.0032 \\
(1.27)\end{array}$ & $\begin{array}{r}-0.0035 \\
(1.45)\end{array}$ & $\begin{array}{r}-0.0036 \\
(1.45)\end{array}$ \\
\hline District Size & $\begin{array}{r}-0.00002 \\
(0.02)\end{array}$ & $\begin{array}{r}-0.00009 \\
(0.12)\end{array}$ & $\begin{array}{r}-0.0001 \\
(0.13)\end{array}$ \\
\hline College & & $\begin{array}{l}0.2094 * * * \\
(4.51)\end{array}$ & $\begin{array}{l}0.2202 * * * \\
(3.70)\end{array}$ \\
\hline Lunch & & $\begin{array}{c}-0.2141 * * * \\
(4.16)\end{array}$ & $\begin{array}{c}-0.2102 * * * \\
(3.98)\end{array}$ \\
\hline Income Diversity & & & $\begin{array}{r}-0.0130 \\
(0.26)\end{array}$ \\
\hline Linguistic Diversity & & & $\begin{array}{r}-0.0134 \\
(0.21) \\
\end{array}$ \\
\hline Number of Observations & 607 & 607 & 607 \\
\hline R-squared & 0.59 & 0.62 & 0.62 \\
\hline
\end{tabular}

Note: Expenditure Per Pupil, Income, Average Teacher Salary, Density, and District Size in thousands.

Absolute value of heteroskedasticity-corrected t-statistics in parentheses.

* indicates significance at the $10 \%$ level, ** at $5 \%$ level and *** at the $1 \%$ level. 
The coefficient on racial diversity from specification $1(-0.2805)$ suggests that a move from complete racial homogeneity to the racial diversity of the Mount Healthy School District (0.498) would lower a district's passage rates on the ninth grade math proficiency test by nearly 14 percentage points. Calculated at the mean, that represents a decline in the average district's passage rates on the ninth grade math proficiency exam by over one standard deviation. Note, however, that a movement in a district's racial diversity score by 0.5 would represent a five standard deviation change. So while the effect of racial diversity on school performance is negative and significant, short-run changes in the racial composition of school districts are unlikely to have a significant effect on test scores. A school district moving one standard deviation away from complete homogeneity is expected to observe a decline in the passage rate on the ninth grade math test by 2.8 percentage points. To put this in context compared to another explanatory variable, a one standard deviation decline in a school district's attendance rate is associated with a 4.6 percentage point fall in math test scores.

Notably, racial diversity is negatively associated with district passage rates holding school spending constant. This provides some indirect evidence that the effect of racial diversity on school performance occurs directly rather than flowing through its negative effect on school spending. Whether this is because of negative peer effects or some other channel is difficult to discern given the methodological approach.

In column 2 of Table 2.2, I control for additional socioeconomic variables that might influence school performance to see if this observed relationship between racial diversity and school performance is robust to alternative specifications. The new controls added to specification 2 are the percentage of district residents with at least a bachelor's 
degree and the percentage of district students eligible for free or reduced price lunch. The percentage of school district residents over 25 with at least a bachelor's degree is obtained from the 2000 Census School District Tabulation and the percentage of district students eligible for free or reduced price lunch is obtained from the Cupp Report.

Both additional variables are statistically significant at the one percent level. As expected, the greater the percentage of school district residents with at least a bachelor's degree, the higher the district's passage rate on the ninth grade math exam. Conversely, the higher the percentage of students eligible for free or reduced price lunch the lower a school district's passage rate on the exam. The impact of racial diversity is reduced slightly by the introduction of these additional variables but remains statistically significant at the one percent level. Here, a district moving from complete racial homogeneity to the middle of the racial diversity spectrum $(0.5)$ is associated with a 12 percentage point decline in district passage rates.

The third column of Table 2.2 provides a final check on the robustness of the OLS results by adding two more explanatory variables to the model. It is possible that in addition to being fractionalized by race, individuals might be fractionalized by class or income. To account for possible stratification of individuals by income, the ratio between the mean and median income in a school district is used as a measure of income diversity.$^{17}$ The second explanatory variable is the degree of linguistic diversity across school district households. Calculated in a manner identical to the racial diversity

\footnotetext{
${ }^{17}$ The ratio of mean to median income is used here instead of a measure similar to the racial diversity variable due to the limited nature of income data for school districts. Here mean income per school district comes from the 2000 Census and median income by school district comes from the Cupp Report.
} 
variable, this variable measures the degree to which individuals in a school district are separated by language barriers. ${ }^{18}$

The inclusion of these additional variables does not change the finding of a strong negative relationship between racial diversity and school performance. The coefficient on racial diversity is nearly identical to the coefficient from the second specification and remains significant at the one percent level. Moving from racial homogeneity to racial diversity of 0.5 is associated with a 12 percentage point decline in math test passage rates. Both the income diversity and linguistic diversity variable are not statistically significant at conventional levels.

\subsection{Results}

It is possible that the direction of causation does not run just from racial diversity to school performance but also from school performance to racial diversity. School districts could become racially fractionalized if household migration in response to school performance is not uniform by race. While it is clear that public school performance is important in intraurban migration (Jud and Bennett 1986), there is little evidence that racial groups systematically differ in their response to school performance. ${ }^{19}$

However, differences across racial groups in response to school performance are not necessary to generate changes in diversity. Even if blacks and whites have similar

\footnotetext{
${ }^{18}$ This variable is calculated from the 2000 Census School District Tabulation (Table P2). Only households that are 'linguistically isolated' are calculated as separate groups.

${ }^{19}$ There is some evidence that Blacks and Whites do systematically differ in residential location patterns. South and Crowder (1997), using data from the Panel Study of Income Dynamics, provide some evidence of these differences. They find that even after standardizing for racial differences in income blacks are far less likely to move from central cities to the suburbs than are Whites. This could be the result of residential housing discrimination or because of different tastes for urban and suburban living.
} 
residential mobility responses to school district performance, school district racial diversity can change solely because the racial composition of new district residents differs from the current composition. Consider the case of a racially diverse suburban school district surrounding a racially homogenous city school district. Since a large portion of intrametropolitan moves are 'up and out' (Bier 2001), the suburban district could become even more fractionalized over time even if blacks and whites move out of the district at the same rate. This is because the composition of new residents differs from the composition of exiting residents.

Even if changes in school district performance do lead to changes in racial diversity, the direction of this change is not clear in advance. Household mobility in response to school district performance could either increase or decrease diversity depending upon the current racial composition of the school district. A situation where a large number of white residents moved and were replaced by black residents could result in a school district become less fractionalized, if black households already comprised a majority share of households within the school district.

Looking at the change in racial diversity over time, Ohio school districts were more racially fractionalized in 2000 than in 1990 as the racial composition of the state changed. The average school district in 1990 had a racial diversity score of 0.077 . By 2000, that number had changed to 0.101 . The correlation between a school district's 1990 graduation rate and the change in racial diversity among district residents from 1990 to 2000 is a positive $0.0515 .{ }^{20}$ It appears that better school districts in 1990 , as measured by graduation rates, actually became more fractionalized, although the correlation between

\footnotetext{
${ }^{20}$ Graduation rates were used instead of math test scores because Ohio had no standardized statewide testing system in place during the 1989-1990 school year.
} 
these two variables in not statistically significant. ${ }^{21}$ This provides some evidence that endogeneity is not a problem.

As an additional check against the possibility that endogeneity is biasing the OLS results, I follow Alesina, Baqir and Easterly (1999) and instrument for racial diversity using lagged values of school district racial diversity. ${ }^{22}$ Each of the three specifications in Table 2.2 was re-estimated, with the 1990 racial diversity variable taking the place of the year 2000 measure. Table 2.3 contains the IV results, which seem to indicate that endogeneity was biasing the OLS estimates presented in Table 2.2 downward. That is, rather than overstating the effect of racial diversity on school performance, the OLS estimates understate the effect of racial diversity on school performance. This is consistent with the fact that better performing school districts in 1990 saw increases in racial diversity over the subsequent decade.

Instrumenting for racial diversity also increases the economic significance of racial diversity. The coefficients on racial diversity for all three specifications increase substantially after instrumentation. Using the coefficient estimate on racial diversity from specification 1, a move from racial homogeneity to a racial diversity score of 0.5 is associated with a 16.5 percentage point decline in district passage rates on the math proficiency exam. This represents a 2.5 percentage point increase over the corresponding estimate from the OLS results.

\footnotetext{
21 The null hypothesis of zero relationship cannot be rejected at the ten percent level of significance ( $\mathrm{z}$ critical value of 1.27).

${ }^{22}$ The Census Bureau prepared the special school district tabulation for the first time for the 1990 Census thus school district data such used to calculate the racial diversity variable is not available for years prior to 1989-1990 school year. Alesina, Baqir, and Easterly (1999) were able to employ data from the 1970 Census because their paper only looked at education spending at the city and county level.
} 
Table 2.3

Racial Diversity and District Math Scores: IV Estimates

\begin{tabular}{lccc}
\hline & 1 & 2 & 3 \\
\hline Constant & $-2.68 * * *$ & $-1.81 * * *$ & $-1.8036 * * *$ \\
& $(6.15)$ & $(4.05)$ & $(3.94)$ \\
Racial Diversity 1990 & $-0.3298^{* * *}$ & $-0.2786 * * *$ & $-0.2779 * * *$ \\
& $(5.65)$ & $(4.72)$ & $(4.75)$ \\
Expenditure Per Pupil & $-0.0069 *$ & -0.0039 & -0.0036 \\
& $(1.66)$ & $(0.93)$ & $(0.84)$ \\
Income & $0.0059 * * *$ & 0.0006 & 0.0006 \\
& $(7.88)$ & $(0.59)$ & $(0.50)$ \\
Attendance & $3.5818 * * *$ & $2.8567 * * *$ & $2.8653 * * *$ \\
& $(7.88)$ & $(6.32)$ & $(6.27)$ \\
Pupil/Teacher Ratio & $-0.0054 * * *$ & $-0.0040 * *$ & $-0.0039 * *$ \\
& $(2.62)$ & $(1.98)$ & $(1.97)$ \\
Average Teacher Salary & $0.0019 *$ & 0.0004 & 0.0004 \\
& $(1.74)$ & $(0.35)$ & $(0.37)$ \\
Teacher Inexperience & $-0.1490 * * *$ & $-0.1376 * * *$ & $-0.1371 * * *$ \\
& $(3.21)$ & $(3.03)$ & $(3.00)$ \\
Density & -0.0030 & -0.0033 & -0.0033 \\
& $(1.07)$ & $(1.24)$ & $(1.24)$ \\
District Size & 0.00008 & -0.00002 & -0.00003 \\
College & $(0.09)$ & $(0.02)$ & $(0.03)$ \\
& & 0.1914 & $0.2016 * * *$ \\
Lunch & & $(4.05)$ & $(3.33)$ \\
Income Diversity & & $-0.2109 * * *$ & $-0.2072 * * *$ \\
Linguistic Diversity & & $(4.06)$ & $(3.92)$ \\
& & & -0.0123 \\
Number of Observations & & & $(0.25)$ \\
R-squared & & -0.0112 \\
Note: Expending & & $(0.17)$ \\
\hline & 0.59 & 0.62 & 607 \\
& & & 0.62 \\
\hline
\end{tabular}

Note: Expenditure Per Pupil, Income, Average Teacher Salary, Density, and District Size in thousands.

Absolute value of heteroskedasticity-corrected t-statistics in parentheses.

$*$ indicates significance at the $10 \%$ level, $* *$ at $5 \%$ level and ${ }^{* * *}$ at the $1 \%$ level. 


\subsection{Sensitivity Analysis}

The fact that the relationship between racial diversity and school performance is consistent across all specifications in the OLS regressions provides some assurance that the association between the two variables is not spurious. The IV results provide some additional confidence that the relationship between racial diversity and test scores are not contaminated by endogeneity. Two possible concerns remain, however, and here I attempt to address them.

The first potential problem is one raised by Alesina, Baqir and Easterly (1999), namely that ethnic diversity might be a proxy for the percentage of the population that is black. Given that the share of black residents is correlated with racial diversity this is certainly plausible. At the same time, the implications of the racial diversity variable and the percentage of residents that are black are much different. Racial diversity treats a school district with racial shares of 60 percent white, 30 percent black and 10 percent 'some other race only' as being equivalent to a school district that is 60 percent black, 30 percent 'some other race only' and 10 percent white. Conversely, the percentage black variable treats the two situations as being quite dissimilar.

As Alesina, Baqir and Easterly (1999) suggest, if percentage black is the 'true' variable reducing school performance, the inclusion of it in the regressions in Table 2.3 should cause the coefficient on racial diversity to go to zero. The first column of Table 2.4 shows the results of controlling for the percentage of district residents that are black. Inclusion of percentage black in the empirical model does lower the coefficient on the racial diversity variable in all three specifications compared to the results in Table 2.3, but the variable remains statistically significant at conventional levels across the board. 
Table 2.4

Racial Diversity and District Math Scores: Sensitivity Analys is

\begin{tabular}{|c|c|c|}
\hline & 1 & 2 \\
\hline Constant & $\begin{array}{l}-1.82 * * * \\
(3.89)\end{array}$ & $\begin{array}{l}-1.82 * * * \\
(3.89)\end{array}$ \\
\hline Racial Diversity 1990 & $\begin{array}{c}-0.1170 * \\
(1.89)\end{array}$ & $\begin{array}{c}-0.1188 * \\
(1.92)\end{array}$ \\
\hline Expenditure Per Pupil & $\begin{array}{r}-0.0013 \\
(0.30)\end{array}$ & $\begin{array}{r}-0.0013 \\
(0.29)\end{array}$ \\
\hline Income & $\begin{array}{r}0.0005 \\
(0.46)\end{array}$ & $\begin{array}{r}0.0005 \\
(0.47)\end{array}$ \\
\hline Attendance & $\begin{array}{l}2.8352 * * * \\
(6.03)\end{array}$ & $\begin{array}{l}2.8358 * * * \\
(6.03)\end{array}$ \\
\hline Pupil/Teacher Ratio & $\begin{array}{c}-0.0036 * \\
(1.79)\end{array}$ & $\begin{array}{c}-0.0036 * \\
(1.79)\end{array}$ \\
\hline Average Teacher Salary & $\begin{array}{r}0.0008 \\
(0.77)\end{array}$ & $\begin{array}{r}0.0008 \\
(0.78)\end{array}$ \\
\hline Teacher Inexperience & $\begin{array}{c}-0.1026 * * \\
(2.32)\end{array}$ & $\begin{array}{c}-0.1016 * * \\
(2.29)\end{array}$ \\
\hline Density & $\begin{array}{r}-0.0025 \\
(1.35)\end{array}$ & $\begin{array}{r}-0.0025 \\
(1.31)\end{array}$ \\
\hline District Size & $\begin{array}{r}0.0003 \\
(0.32)\end{array}$ & $\begin{array}{r}0.0003 \\
(0.33)\end{array}$ \\
\hline College & $\begin{array}{l}0.1952 * * * \\
(3.34)\end{array}$ & $\begin{array}{l}0.1962 * * * \\
(3.37)\end{array}$ \\
\hline Lunch & $\begin{array}{c}-0.1877 * * * \\
(3.68)\end{array}$ & $\begin{array}{c}-0.1877 * * * \\
(3.68)\end{array}$ \\
\hline Income Diversity & $\begin{array}{r}-0.0140 \\
(0.29)\end{array}$ & $\begin{array}{r}-0.0136 \\
(0.28)\end{array}$ \\
\hline Linguistic Diversity & $\begin{array}{r}-0.0541 \\
(0.86)\end{array}$ & $\begin{array}{r}-0.0453 \\
(0.69)\end{array}$ \\
\hline Black & $\begin{array}{c}-0.0027 * * * \\
(4.86)\end{array}$ & $\begin{array}{c}-0.0027 * * * \\
(4.80)\end{array}$ \\
\hline Private School & & $\begin{array}{r}-0.0175 \\
(0.39) \\
\end{array}$ \\
\hline Number of Observations & 607 & 607 \\
\hline R-squared & 0.64 & 0.64 \\
\hline
\end{tabular}

Note: Expenditure Per Pupil, Income, Average Teacher Salary, Density, and District Size in thousands.

Absolute value of heteroskedasticity-corrected t-statistics in parentheses.

* indicates significance at the $10 \%$ level, ** at 5\% level and *** at the $1 \%$ level. 
Employing the coefficient on racial diversity from the third specification, a move from racial homogeneity to a score of 0.5 would result in fall in passage rates on the math proficiency exam of around 5.5 percentage points.

A second potential problem is the presence of private schooling. Clotfelter (1976) finds that desegregation has a significant effect on private school enrollment. Racial integration could lead to lower test scores if integration caused the better students in the district to respond by switching to private schools. Thus, our results might be showing that racially diverse school districts have lower test scores not because of the effect of diversity on the provision of education within the district, but rather because the better students in the district are attending private schools. The second column of Table 2.4 addresses this issue by including the percentage of district children aged 5-17 that attend private schools as an independent variable. This 2000 Census variable is not statistically significant and, more importantly, does not affect the impact of racial diversity on school district performance. Thus while migration to private schools may be a response to integration, it is does not influence the relationship between racial diversity and school district performance.

\subsection{Concluding Thoughts}

In this article, I demonstrate a negative relationship between racial diversity and school district performance. A school district moving from perfect racial homogeneity to a situation where two racial groups that had equal shares (a racial diversity score of 0.5 ) could expect a decline in district passage rates on the ninth grade math test of between 5.5 and 16.5 percentage points percentage points. While not insignificant, these results 
should be taken with a grain of salt as a 0.5 change in a school district's racial diversity score represents a five standard deviation change. A fairly large one standard deviation increase in racial diversity is associated with a much smaller decline in district math test scores of between 1.1 and 3.3 percentage points. At the same time, however, these results provide the first estimate that the net effect of racial diversity on school performance is negative. While the empirical approach here cannot identify the exact channels through which racial diversity lowers school performance, identification of the negative relationship is an important first step.

This finding suggests that the opportunity exists for improvement in education outcomes in the most racially diverse schools if ways to mitigate the negative effect of racial diversity on school district performance can be discovered. It is likely, however, that overcoming the effect of racially diversity on school district performance will not be easy or desirable, especially given the alternatives. For example, Alesina, Baqir and Easterly (1999) note that the results of the ethnic, linguistic, and racial diversity literature appear to suggest that the solution to low levels of public goods provision is segregation and decentralization. This, however, is not a tenable solution for two reasons. First, people value diversity as well as school performance and might be perfectly happy to trade-off reduced performance for living in an integrated environment. Maximizing school performance is not the same thing as maximizing utility and many factors go into deciding where to live and attend school besides school performance (Pritchett and Filmer 1999). Second, segregation is not ideal in the long-run if integration increases the speed of preference homogenization (Bénabou 1996). 
My results have three important implications for research on the effects of race on academic achievement. First, research into the effect of racial concentration on student achievement needs to consider the voting channel as well as the peer effect channel. Second, social scientists need to look more closely at the net effect of diversity on student achievement. The racial peer effect literature seems to be clear that increased diversity is good for black students. What is not clear is whether increased diversity is good for students of all racial groups. ${ }^{23}$ Finally, more work needs to be done on estimating through which channels diversity effects operate. Does racial diversity could lead to lower net test scores because the negative voting effect dominates the positive peer group effect? Or is the voting effect negligible but overall learning lower in diverse districts because there are both positive and negative racial peer effects and the negative dominates the positive. ${ }^{24}$ The answers to these important questions await further research.

\footnotetext{
${ }^{23}$ In fact, the relationship between integration and school performance for black students may not be linear. Echenique, Fryer, and Kaufman (2006) find that integrated schools often have in-school segregation that leads to lower test scores. Schools where more than 25 percent of the students are black are actually more segregated in terms of social interactions than schools with fewer black students.

${ }^{24}$ Hoxby (2000b) finds that black, Hispanic, and white third graders all do worse academically as the percentage of their classmates that are black increase. Her results are consistent with there being circumstances where the net effect of increased diversity is negative. The same is true with Echenique, Fryer and Kaufman (2006), who find that Asians are more likely to have high test scores when they are segregated within a school.
} 


\section{Chapter 3 \\ Does Tiebout Move or Vote? Fiscal Competition, Yardstick Competition, and Income Tax Use}

\subsection{Introduction}

In his influential 1956 paper, Charles Tiebout suggested that 'consumer-voter' mobility among local governments could approximate a competitive market setting if the number of local communities was sufficiently large (Goodspeed 1998). Tiebout's goal was to show how local public goods could be provided in a world without politics (Fischel 2001). Conventional wisdom among public finance economists is that local governments do face strong competitive pressures from mobile households (Mieskowski and Zodrow 1989). 'Voting with your feet' is thus commonly viewed as being analogous to voting with your pocketbook in conventional market settings, so much that voting at the ballot box is often viewed as inconsequential to the level and quality of goods provided by local governments. Horizontal competition among governments has been found to improve efficiency in a variety of settings. ${ }^{25}$

This 'Tiebout-style' fiscal competition among local governments is thought to limit the ability of local governments to levy non-benefit taxes, i.e., taxes where the level

\footnotetext{
${ }^{25}$ In education there is a large literature showing a positive relationship between the degree of interjurisdictional competition among school districts and school efficiency. See, for example, the work of Staley and Blair (1995) and Hoxby (2000a). Building off the work of Brennan and Buchanan (1980) on constraining Leviathan, Stansel (2006) finds slower government growth in more competitive areas. His work is consistent with previous findings of Schneider (1986) and Zax (1989).
} 
of benefits is not commensurate with level of taxation (Oates 1999). ${ }^{26}$ The mobility of households prevents local governments from engaging in redistribution because mobile households will 'vote with their feet' and move to a nearby community with less redistribution. In this manner, fiscal competition among local governments could also affect the tax structure adopted by local governments. Spry (2005) finds that fiscal competition for mobile households limits the use of residency-based income taxes. Given the widely-held view in public finance that governments should diversify across as many tax bases as possible for revenue stability (the so-called 'three-legged stool' analogy), this finding could have important policy implications.

This paper provides evidence that horizontal competition among local governments does not act as a constraint on the use of residency-based income taxes. Caplan (2001) develops a model where the complete capitalization of property taxation into home prices means that 'voting with your feet' cannot be a way for homeowners to escape unwanted taxation. ${ }^{27}$ Homeowners have to pay the tax regardless, either directly in tax payments to the local government, or indirectly, through a lower selling price for their home. ${ }^{28}$ Powell (2004) extends Caplan's findings to include any tax that is capitalized in housing prices. ${ }^{29}$

\footnotetext{
${ }^{26}$ I use the terminology fiscal competition, interjurisdictional competition, and 'voting with your feet' interchangeably because all describe the same phenomena where exit to nearby districts creates competitive pressure. Yardstick competition is different because the competitive process is through 'voice', i.e., politics.

${ }^{27}$ See Palmon and Smith (1998) for evidence that property taxes are completely capitalized into home prices.

${ }^{28}$ This is because the new owners recognize the future steam of tax payments associated with purchasing the home and reduce their willingness to pay by the amount of the discounted future tax payments.

${ }^{29}$ An income tax based on a individual's residence is capitalized into home prices in a manner similar to the property tax thus Caplan's conclusions should hold for the residency-based school district income tax examined here.
} 
Caplan (2001) argues that it is the political process that forces local governments to conform to the preferences of the median voter, not interjurisdictional competition. My argument is similar, except that here other local governments are important, not as a means of escape, but as a means of comparison. I argue that yardstick competition among local governments is a significant factor in the choice of an income tax. Yardstick competition, formalized by Besley and Case (1995), suggests that voters in one locality utilize information from surrounding localities in making their decisions. In an approach similar to the one employed here, Fiva and Rattsø (2007) find that yardstick competition helps explain local government adoption of the property tax in Norway.

The empirical approach used to identify yardstick competition has the added benefit of providing unbiased estimates of the effect of fiscal competition among governments. In the presence of spatial dependence, non-spatial estimates can be biased, inconsistent, or both (Anselin 1988), thus a finding of spatial interaction casts doubt on the robustness of variable such as measures of interjurisdictional competition that are correlated in space. Brasington (2007) demonstrates that failing to account for spatial dependence among local governments can lead to an upward bias in empirical estimates of interjurisdictional competition. The statistical and economic significance of fiscal competition measures often disappear once spatial dependence among local governments is properly taken into account.

This paper shows that yardstick competition matters in the choice of whether or not to adopt a residency-based income tax using data on Ohio school districts. This institutional context was chosen so as to be directly comparable with past research that finds a significant negative relationship between fiscal competition and tax instruments 
choice (Spry 2005). In addition, I find that failure to account for spatial dependence in tax instrument choice has biased previous estimates, most notably measures of competition among local governments. The negative influence of interjurisdictional competition on income tax usage disappears once spatial dependence is taken into account.

Section 2 presents an overview of the institutional setting and the data. Section 3 provides a first look at possible yardstick competition in the data. Section 4 discusses the empirical approach adopted to meet the two goals of this paper and then Section 5 follows with the empirical results. Section 6 concludes.

\subsection{Data}

To investigate the relative role of 'voting with one's feet' and yardstick competition in the determination of local government tax structure, I look at a cross-section of Ohio school districts for the 1996-1997 school year. ${ }^{30}$ Ohio is one of only two states that allow school districts to choose between a property tax and an income tax. Thus the data set presents a unique opportunity to study the impact of yardstick and interjurisdictional competition on local government tax structure. While Ohio school districts are required to raise revenue through property taxation, in 1989 the Ohio state government gave school districts the option of also levying a residency-based income tax. (Busch, Stewart, and Taub 1999). That first year 17 school districts received voter approval to tax income and by the 1996-97 school year 119 of the 611 school districts in the state used the income tax.

\footnotetext{
${ }^{30}$ As this paper is, in part inspired by and a comment on the work of Spry (2005), the year of analysis and variable choices are initially chosen so as to be as directly comparable to his results as possible.
} 
The dependent variable for the analysis is a binary variable equaling one if a school district utilized an income tax during the 1996-97 school year and zero if a school district did not. Following Spry (2005), fiscal competition or 'voting with one's feet' is measured as the number of other school districts within ten miles of a district. ${ }^{31}$ This variable can be thought of as representing the 'cost' of voting with one's feet. As the number of nearby districts increases, the cost of finding a nearby district to move to falls and reduces the ability of localities to extract revenue from high-income taxpayers. Thus the hypothesized relationship between the number of districts within 10 miles and the use of the income tax is negative. ${ }^{32}$

I follow Spry (2005) in my choice of explanatory variables in order to facilitate direct comparison of estimated parameter coefficients. Of primary importance in the choice of tax structure is the ability to export the tax burden of education onto nonresidents, since they cannot vote in district elections. As the income tax is residencybased, the entire burden of the tax falls on district residents unlike the burden of the property tax which can be exported to some extent onto non-resident landowners and consumers. For example, Norstrand (1980) and Sjoquist (1981) find that local governments are more likely to use the property tax when it is viewed as being exported onto non-residents. The percentage of taxable property that is business property (commercial, industrial, or public utility) is included to measure the ability of a community to export the property tax burden. The greater the percentage of property

\footnotetext{
${ }^{31}$ Originally calculated by Spry (2005), the variable is measured as the number of districts whose geographic center is ten miles from the geographic center of the district being analyzed.

32 Another measure of interjurisdictional competition that is frequently used is a Herfindahl index measuring the local government's share of the total city or MSA government in terms of population or land area. Hall (2006) confirms Spry's (2005) finding that Tiebout mobility matters using a similar data set but measuring the degree of interjurisdictional competition using a Herfindahl index.
} 
within a school district that is business, the lower the probability should be that it would use the income tax since doing so for any fixed level of spending would likely increase the burden on local voters. The percentage of taxable property that is mineral is included for similar reasons and with similar expectations regarding its sign.

The percentage of property that is in agricultural use is included to account for the fact that farmers are generally property-rich but income-poor and thus would likely vote for an income tax over a property tax of a similar amount. ${ }^{33}$ Shock (2004-2005) analyzes voting behavior in over 1,200 school district elections in Ohio and finds that the percentage of agricultural property strongly predicts the passage of an income tax. A positive relationship is also expected between the percentage of a school district's residents that are renters and the school district income tax. Shock (2004-2005) finds this relationship in his study of voting behavior but Spry (2005) finds the opposite relationship (although the finding is not statistically significant).

There is a large literature showing the effect of the elderly on school spending (Button 1992; Poterba 1997; Berkman and Plutzer, 2004; Brunner and Baldson 2004). There are two reasons to think that elderly voters would be in favor of an income tax. First, elderly homeowners are likely to see their tax burden fall when the income tax is used because senior citizens tend to have lower incomes and higher property values. Second, elderly homeowners are more likely than the average homeowner to own their home outright. Thus their property tax payments are lump-sum payments to the auditor instead of being collected with their mortgage payment and being held in escrow. The fiscal illusion created by paying property taxes together with the mortgage is reduced for

\footnotetext{
33 The classification of property that is excluded to prevent singularity is the percentage of property that is residential.
} 
many elderly taxpayers, thus they may be more anti-property tax than would be explained by the first reason.

From the perspective of the median voter, the likelihood of an income tax being utilized is expected to decline as the 'price' of the income tax increases to the median voter. The income tax price for the median voter is calculated by multiplying one thousand times the median adjusted gross income in a school district divided by the total adjusted gross income in the school district. The higher the income tax price to the median voter, the less likely it is that a school district will utilize the income tax. The median voter pays property taxes as well, thus the property tax price of taxation is likely to influence the adoption of an income tax. The property tax price is calculated as the median price of owner-occupied housing in the school district times the residential assessment ratio divided by total property tax value in the district. ${ }^{34}$ As the property tax price to the median voter increases, use of the income tax is expected to increase.

The final two explanatory variables included in the benchmark analysis are variables used in previous research: the percentage of district residents that live in a rural area, and a binary variable equaling one if the school district is located inside a local government that also levies a local income tax. ${ }^{35}$ Rural residency is thought to be positively correlated with the adoption of a school district income tax beyond being involved in agriculture although a theoretical reason has not yet been given. Perhaps nonfarmer rural voters tend to identify with the interests of their neighbors engaged in

\footnotetext{
${ }^{34}$ In Ohio, the assessment ratio on real property is 35 percent. Homes are appraised every six years in Ohio at full market value, thus 35 percent of the full market value of a home represents its taxable value.

${ }^{35}$ The borders of school districts and municipal governments in Ohio are not contiguous, thus this measure is imprecise because it only reflects if a portion of school district residents have to pay a municipal income tax. Unfortunately, the data do not exist to calculate a more precise figure.
} 
agriculture, or are like the elderly in that they tend to have more property than income. The binary variable called 'city tax' is thought to measure competition among local governments for the income tax base. The expected sign on this variable is ambiguous. Spry (2005) makes the case that the expected relationship is negative because use of the income tax by local cities would 'crowd out' attempts by the school district to adopt the tax. He finds, however, that the relationship between the city tax and the school district tax is positive. This finding is not inconsistent with yardstick competition in that voters observing an income tax in use at the municipal level have information on its positives and negatives. If the benefits outweigh the positives, the relationship between city tax and school district income tax adoption will be positive.

The data come from three sources. Demographic variables on school district residents were obtained from the National Center for Education Statistics (1994) 'School District Data Book. ${ }^{36}$ The publication tabulates school district information for all U.S. school districts from answers on the 1990 Census long form. Data on assessed valuation by property type and school district income tax information comes from various publications of the Ohio Department of Taxation (2007) and the Ohio Department of Education (2007). ${ }^{37}$ The number of school districts within 10 miles was calculated by Spry (2005) using Geographic Information System maps from the U.S. Census Bureau. Data on the median home value and median income in a school district, used to calculate

\footnotetext{
${ }^{36}$ The original school district data book came on 44 CD-ROMs from the National Center for Education Statistics. The National Bureau of Economic Research has purchased and made available a more user-friendly version of the data at: www.nber.org/sddb/.

${ }^{37}$ A full description of the publications used to calculate the fiscal variables can be found in Spry (2005, Table 1), but this data appears to now be exclusively available online at: www.tax.ohio.gov/divisions/tax_analysis/tax_data_series/school_district_data/publications_tds_s chool.stm.
} 
the property-tax price and income tax price variables, were obtained from the Ohio Department of Education (2007). Table 3.1 presents summary statistics for the variables.

Table 3.1

Summary Statistics for Ohio School Districts, 1996-97 School Year

\begin{tabular}{lrrrc}
\hline \multicolumn{1}{c}{ Variable } & Mean & Min & Max & $\begin{array}{c}\text { Standard } \\
\text { Deviation }\end{array}$ \\
\hline School District Income Tax & 0.20 & 0 & 1 & 0.397 \\
Number of Districts Within 10 Miles & 4.21 & 0 & 19 & 3.536 \\
Business Property \% & 0.36 & 0.050 & 0.88 & 0.146 \\
Mineral Property \% & 0.00 & 0 & 0.04 & 0.005 \\
Agricultural Property \% & 0.11 & 0 & 0.47 & 0.107 \\
Renters \% & 0.24 & 0.051 & 1 & 0.099 \\
Elderly \% & 0.23 & 0 & 0.45 & 0.055 \\
Income Tax Price & 0.40 & 0.004 & 41.67 & 1.746 \\
Property Tax Price & 0.24 & 0 & 2.54 & 0.233 \\
Rural \% & 0.54 & 0 & 1 & 0.413 \\
City Tax & 0.64 & 0 & 1 & 0.481 \\
\hline
\end{tabular}

\subsection{Follow My Neighbor: A First Look}

Figure 3.1 shows a map of Ohio school districts. The grey districts are those that were using the school district income tax to raise revenue during the 1996-1997 school year. As noted by Spry (2005), the school district income tax appears to be clustered primarily in rural areas with less interjursidictional competition. This would appear to be consistent with the income tax being adopted in locations where there is a greater cost to "voting with your feet.'

A process where district residents observe an income tax in use in nearby districts and vote for its adoption in their home district is consistent with this clustering of districts as well. The previous literature has found a positive relationship between the property tax price the median homeowner faces and the probability of adopting an income tax. 
Districts with high property tax prices and without other factors found to depress income tax adoption such as a large amount of business tax property were likely to have been 'first adopters' when Ohio's school districts were first given the ability to tax income in 1989.

Figure 3.1

Ohio School Districts with an Income Tax, 1997

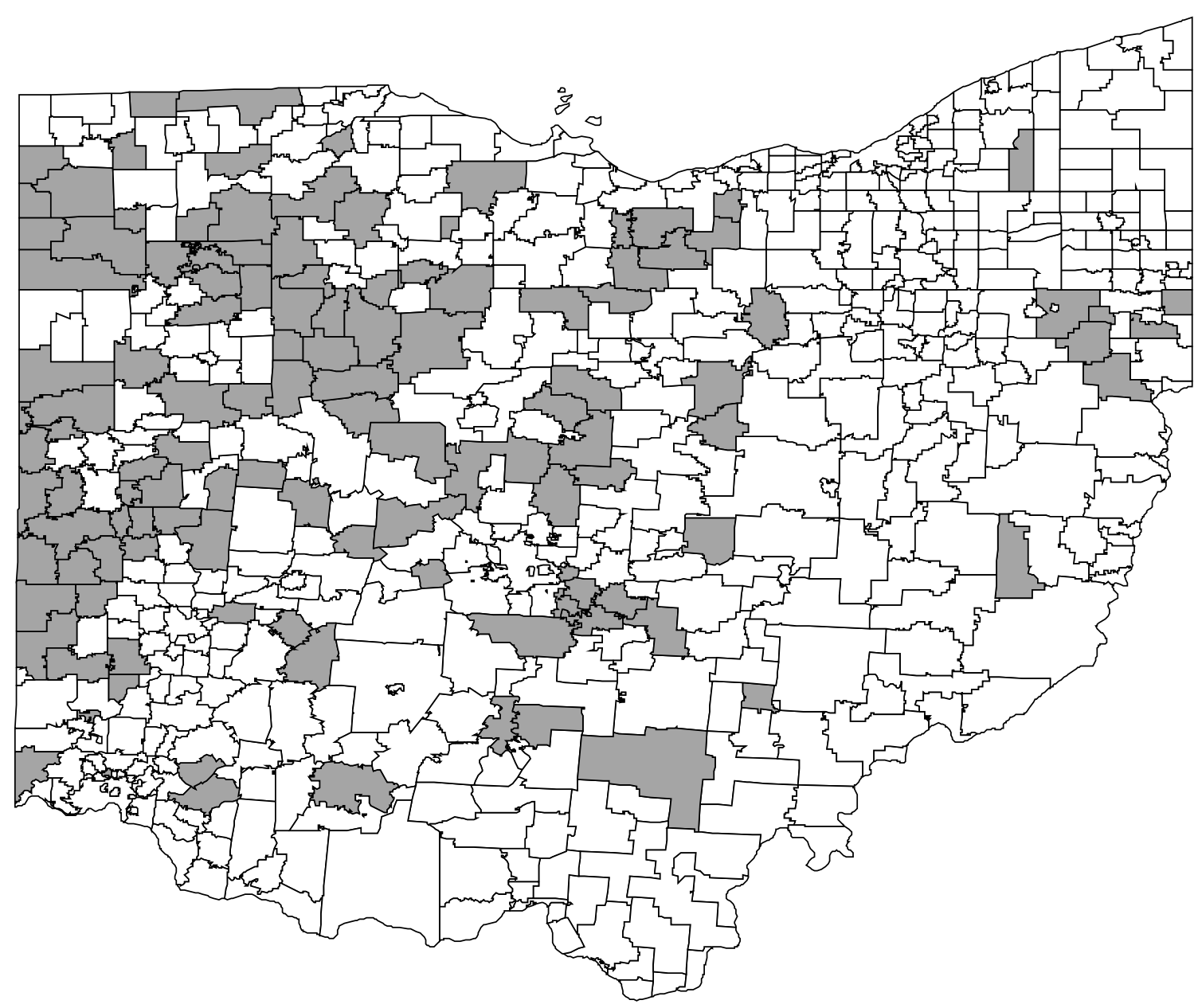

Note: Districts in gray are those using the school district income tax during the 1996-97 school year.

A good example of this would be in Mercer County in the western part of Ohio on the Indiana border. The first district in the area to adopt an income tax was the Coldwater school district in 1990. The property tax price facing the median homeowner in 
Coldwater was 0.71 , two standard deviations above the state mean. In 1991, neighboring Fort Recovery joined them in using the income tax (property tax price 0.45 ). Two other neighboring districts with property tax prices of 0.36 and 0.09 joined them in 1996 . Thus, by 1997 four out of the six school districts in the county had adopted a school district income tax.

Figure 3.2 graphically presents this adoption process for Mercer County with the number of districts in the county is presented on the $y$-axis and the year is on the x-axis. The figure shows that as time progresses from 1989, the number of districts in the county using an income tax to raise revenue goes from zero to four.

Figure 3.2

Income Tax Use in Mercer County, 1989-1997

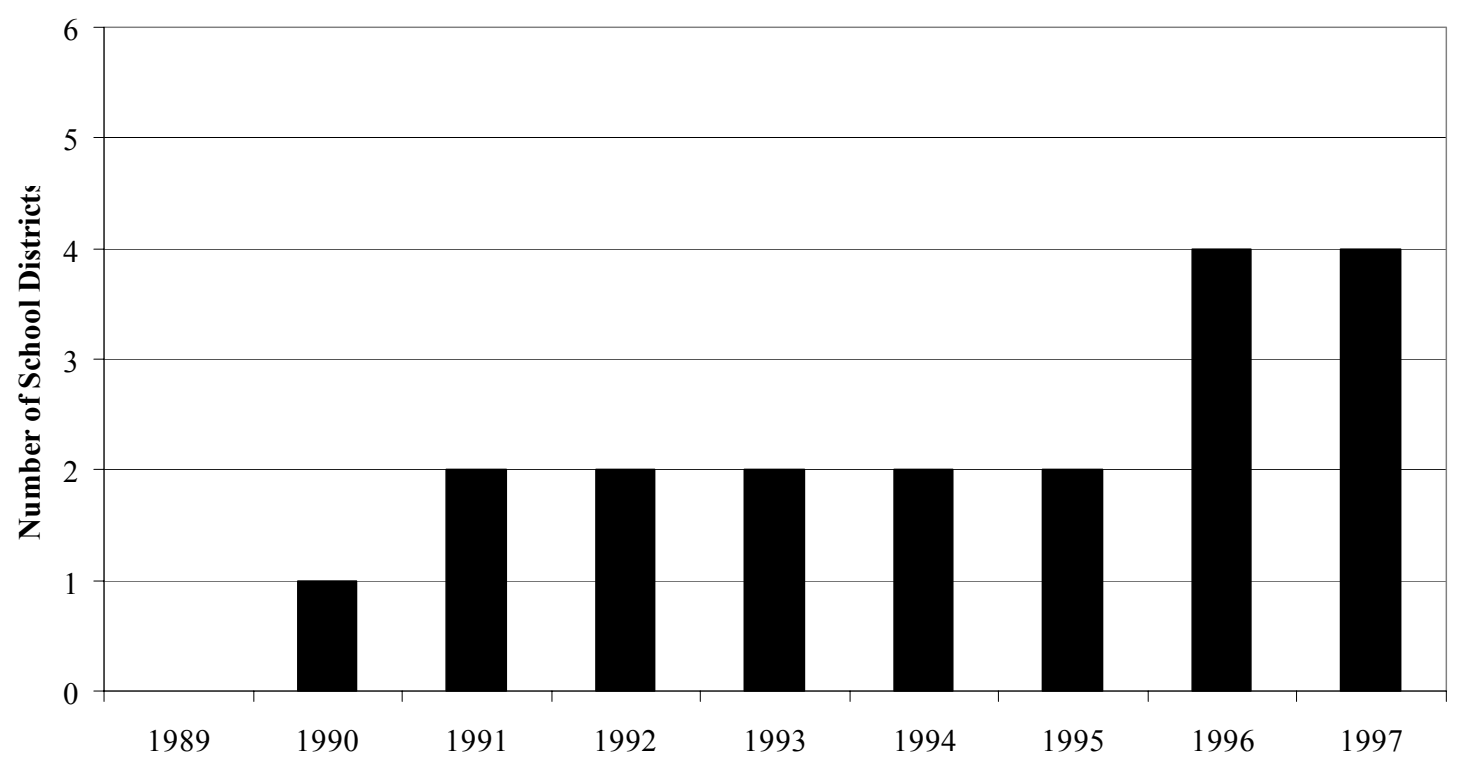

Figures 3.3-3.5 present a similar graphical analysis of income tax adoption over time for three additional counties where the income tax is prevalent. The same pattern holds. Figure 3.5, for example, shows Miami County (near Cincinnati) starting with zero 
districts using the income tax in 1989 and having one district adopt an income tax per year until 1994.

Figure 3.3

Income Tax Use in Darke County, 1989-1997

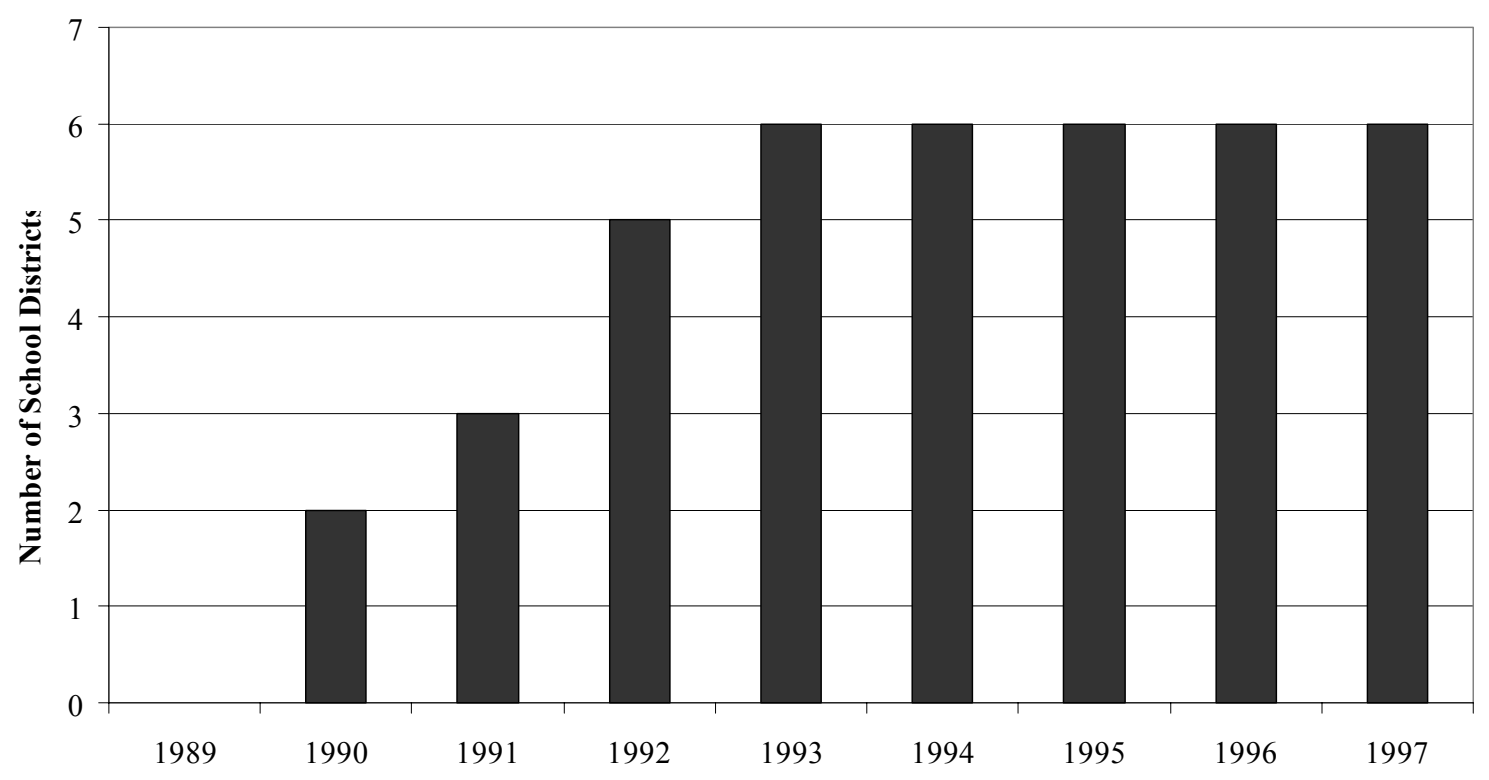

Figure 3.4

Income Tax Use in Miami County, 1989-1997

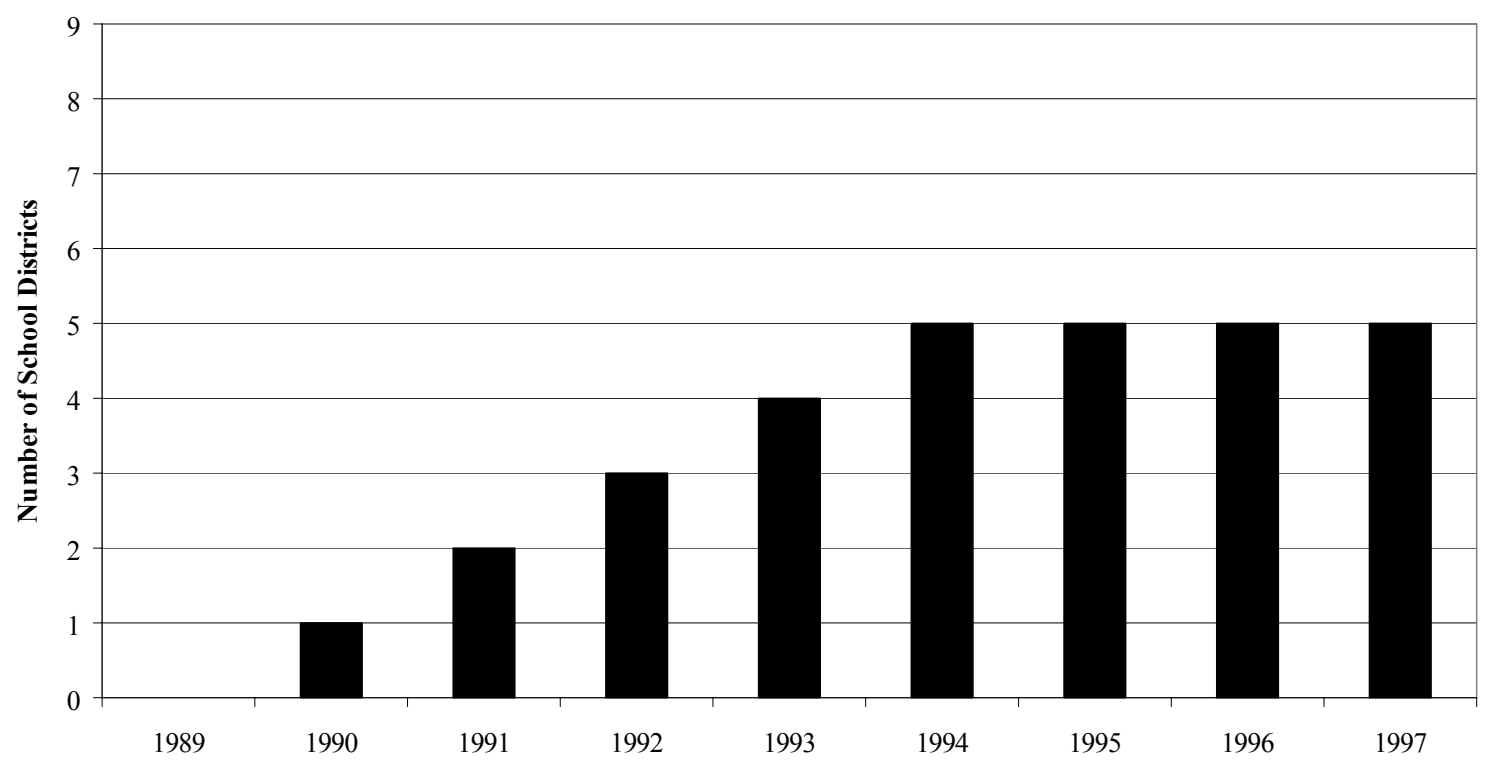


Note that yardstick competition clearly is not the only factor leading to adoption of an income tax. If it was, then the income tax would eventually spread to all school districts in Ohio. The factors that are negatively related to income tax adoption, such as the ability to export part of the tax burden through the taxation of business property, limits the geographic spread of income tax usage. In Miami County, for example, the remaining districts that have not adopted the income tax since 1996 have either a very high income tax 'price' or the district has a lot of business property (or both).

Figure 3.5

Income Tax Use in Putnam County, 1989-1997

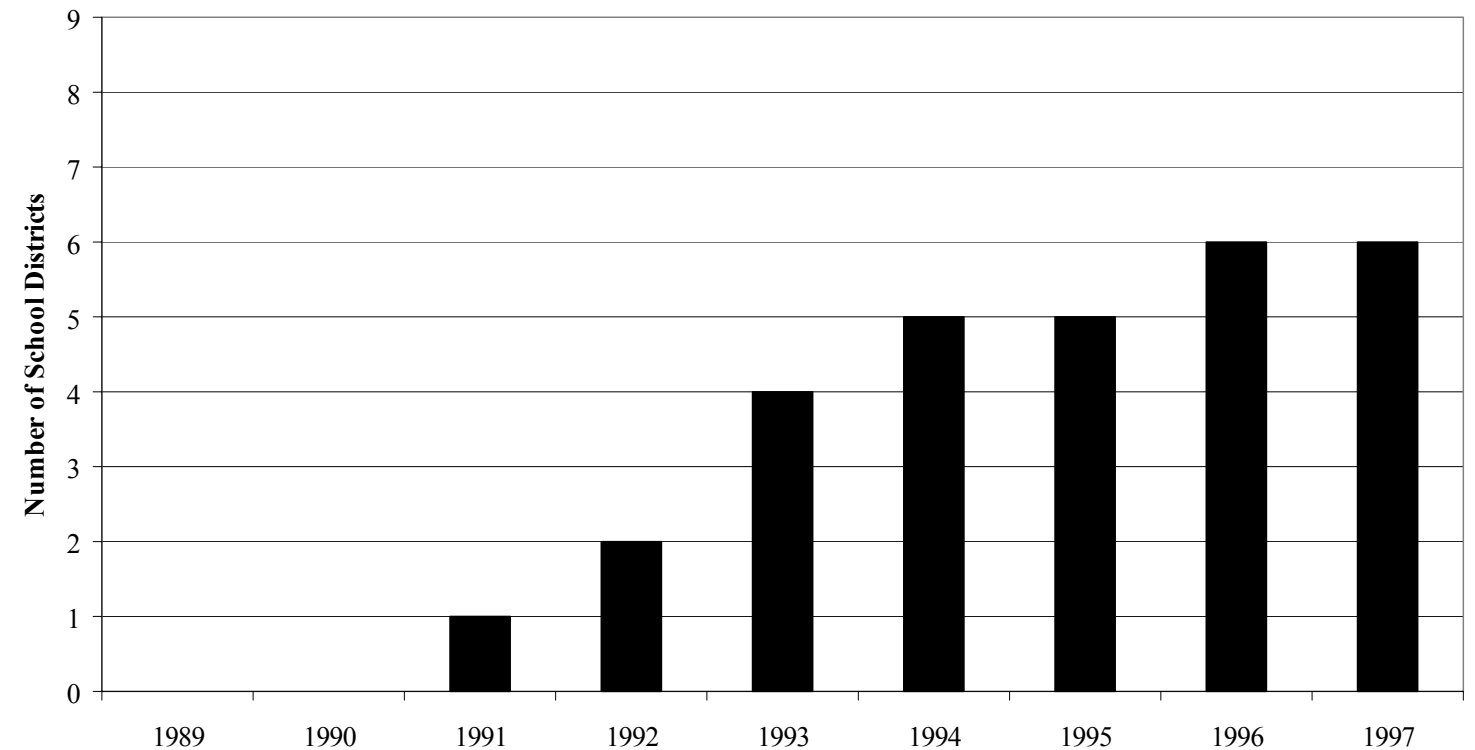

The spatial relationship presented in Figure 3.1 showing the usage of the school district income tax in 1997 presents a picture consistent with spatial dependence in the choice of an income tax. The graphical time-series evidence presented in Figures 3.2-3.5 provides evidence of yardstick competition in the adoption of the income tax as usage of the income tax seems to spread geographically within a county over time. While not proof of yardstick competition in the use of the income tax, these cases are suggestive of 
such a relationship. At the same time, they are not incompatible with there being a negative relationship between fiscal competition and income tax adoption. To further isolate statistically the importance of yardstick and fiscal competition in the choice of an income tax the remainder of the paper discusses and presents an economic analysis isolating these effects.

\subsection{Empirical Approach}

The traditional approach to answering the question of the effect of interjurisdictional competition on income tax adoption would begin by estimating a standard probit model of the form:

$$
S D I T_{i}=\alpha+\beta_{1} \operatorname{WITHN}_{i}+\sum_{x=1}^{X} \beta_{x} Z_{x, i}+\varepsilon
$$

where SDIT is the binary variable identifying if school district i levied a school district income tax during the 1996-97 school year; WITHIN10 is the number of school districts within ten miles of school district $\mathrm{i}$; and $\mathrm{Zi}$ is a vector of the remaining explanatory variables representing other demographic and financial variables at the school district level. The coefficient of primary interest is $\beta_{1}$, because it measures the effect of Tiebout competition on the tax structure adopted by school districts. This is the approach adopted by Spry (2005).

If there is no spatial dependence among school districts, the estimation of equation (1) by log-likelihood is appropriate. If, however, the likelihood of a school district adopting an income tax is in part a function of whether one's neighbors have adopted an income tax, then the results of the standard probit analysis can be biased, 
inconsistent, or both (Anselin 1988). The geographic pattern of income tax adoption visible in Figure 3.1 is consistent with there being spatial dependence in the dependent variable. Brasington (2007) has found that the failure to control for spatial dependence in education production functions leads to estimates of the effect of interjurisdictional competition on outcomes being overstated. More generally, failure to take into account actual spatial dependence potentially biases all parameter estimates and voids subsequent hypothesis testing. Thus the empirical approach described here not only detects yardstick competition among local school districts but also corrects for potential bias and erroneous findings of significance resulting from uncorrected spatial dependence.

Here I address this potential problem by using two different models of spatial dependence. The first model is a Bayesian version of what is commonly referred to as a spatial probit lag model or spatial autoregressive probit model (SARP). ${ }^{38}$ A general overview of the SARP model can be found in LeSage (1999) but the basic idea can be obtained by analogy to an autoregressive (AR) model in time-series analysis. Just as an AR model includes lags over time to reflect that fact that a dependent variable might be influenced by its own value in previous periods, the SARP model includes lags over geographic space. In the context of school districts, one spatial lag from district $i$ would encompass all contiguous neighbors, with each subsequent lag enveloping the neighbors of district $i$ 's neighbors.

The estimating equation for the SARP model is very similar to the traditional probit model with one exception:

\footnotetext{
${ }^{38}$ This is sometimes called a 'spatial latent variable approach.' See, for example, Fiva and Rattsø (2007) or Rincke (2006).
} 


$$
\operatorname{SDIT}_{i}=\alpha+\rho \cdot W \cdot S D I T+\beta_{1} \operatorname{WITHIN10}_{i}+\sum_{x=1}^{X} \beta_{x} Z_{x, i}+\varepsilon
$$

The primary difference between the traditional probit model and the SARP mode is the $\rho \cdot W \cdot S D I T$ term. The $\mathrm{W}$ is a 'spatial weight matrix,' a symmetrical matrix that summarizes the spatial configuration of Ohio school districts on a map. ${ }^{39}$ The number of rows and columns in the matrix is determined by the number of school districts in Ohio, in this case $607 .^{40}$ For each school district in the sample the matrix specifies that district's geographic neighbors based on first-degree contiguity. ${ }^{41}$ For example, if the school district in row one had only two geographic neighbors, its neighbors would receive ones in their respective columns. All other columns for row one are given zeros as they represent the district itself or non-contiguous neighbors. Before being employed in regression analysis the weight matrix is standardized so that each row equals unity with each contiguous neighbor receiving equal weight. So for the school district represented in row one with two contiguous neighbors, each neighbor would have a weight of 0.5. A district with three neighbors would each receive a weight of 0.33 , and so on. This is done for interpretation reasons.

If $\rho$, the coefficient on the spatial weight matrix, is statistically different from zero there is evidence of spatial dependence in the dependent variable. The estimate of spatial dependence can be thought of as the reaction function of a school district to its own characteristics and the use of the school district income tax in nearby districts (Brueckner and Saavedra 2001). Theoretically, yardstick competition can result in the reaction

\footnotetext{
${ }^{39}$ LeSage (1997) provides a good overview of the construction of weight matrixes.

${ }^{40}$ While Ohio had 611 school districts during the 1996-97 school year, four districts had to be excluded from the analysis because of missing or censored data.

${ }^{41}$ There are many other possible weight matrixes. First degree contiguity is the most popular.
} 
function being either positive or negative depending upon parameter estimates, thus empirical evidence is necessary to determine if the presence of an income tax in neighboring districts has a positive or negative effect on use of the income tax. Following Fiva and Rattsø (2007), a value of $\rho$ statistically different from zero is taken as evidence that yardstick competition matters in the choice of the income tax by school districts.

The Bayesian SARP model is employed to deal with heteroscedasticity introduced by the non-spherical variance-covariance matrix created by the SARP. In his survey of different methods of dealing with heteroskedasticity in discrete dependent variable spatial models, Fleming (2004) concludes that the Bayesian approach pioneered by LeSage (2000) is the superior approach to dealing with this problem. The advantage of the Bayesian approach is that it allows for heteroskedastic error terms while making sure that heteroskedasticity is not leading to inconsistent parameters. An excellent overview of the Bayesian SARP model can be found in Fiva and Rattsø (2007).

The Bayesian SARP method developed (and explained in greater detail) by LeSage (2000) is a Markov Chain Monte Carlo (MCMC) method using a Gibbs Sampler process, which is repeated a large number off times to obtain conditional distributions for the model parameters. The Gibbs Sampler process requires a large number of 'draws' to derive conditional distributions for all the parameters. According to MCMC convergence diagnostics the process converges after roughly 950 draws with the first 15 'burned-off' to allow the sampler to reach a steady-state. The results here are all based on 1000 draws with the first 50 excluded. ${ }^{42}$

\footnotetext{
${ }^{42}$ As a check on the MCMC diagnostics, the baseline model specifications in Table 2 were run with 5,000, 10,000, and 20,000 draws and the parameter estimates were basically unchanged.
} 
Relying on a finding that $\rho$ is non-zero and significant in the SARP model as evidence of yardstick competition is problematic since the SARP model assumes that the variance-covariance matrix of the error term is not spatially dependent. Spatial dependence can arise in the error term for many reasons, however, and thus the finding of yardstick competition might be a 'false positive'. A frequent cause of false positive is omitted variable bias caused by an incorrect model specification. Omitted variable bias will not create a false positive if the omitted variables are not spatially dependent. If, however, the omitted variables are spatially dependent then they will be picked up in the error term. Failure to account for spatial error dependence can give rise to the false positive because the spatial lag term $\rho$ is likely to reflect the uncorrected for spatial error correlation created by the omitted variables. ${ }^{43}$ In the case of the linear spatial model there exist several approaches to addressing this problem. ${ }^{44}$ Unfortunately, these approaches are not valid for spatially limited dependent variable models (Fiva and Rattsø 2007).

The second model of spatial dependence employed, the spatial Durbin model, overcomes this problem. Pace and LeSage (2007) find that estimates from the spatial Durbin model are not affected by spatial dependence in the error term or the dependent or independent variables. They conclude that the ability of the spatial Durbin model to deal with this omitted variable bias provides a strong econometric motivation for its use. Here I employ a Bayesian probit version of the model, called the Spatial Durbin Probit (SDP) model, which takes the following form:

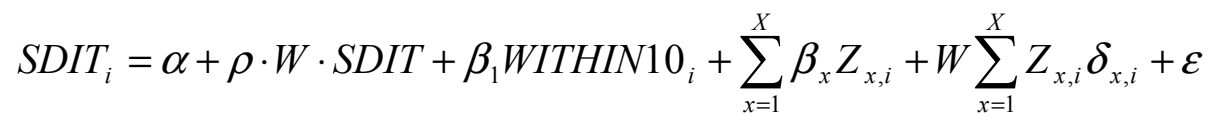

\footnotetext{
${ }^{43}$ See Brueckner and Saavedra $(2001,212)$ for further discussion of this issue.

${ }^{44}$ Anselin (2002) provides an overview of these procedures.
} 
In equation (3), the second $Z_{x}$ matrix is the still the matrix of independent variables only this time it is multiplied by the spatial weight matrix. In this manner the term corrects for spatial dependence in the independent variables as well as in the dependent variable. The $\delta_{x}$ coefficients thus pick up the extent to which the demographic variables of nearby districts influence the decision to adopt an income tax in the original school district. This approach significantly reduces bias in cross-section results by eliminating spatially dependent omitted variable bias (Pace, Barry, and Sirmans 1998; Brasington and Hite 2005; Pace and LeSage 2007). ${ }^{45}$ In the presence of spatial dependence in the error term, this will be the appropriate specification. ${ }^{46}$

\subsection{Empirical Results}

The first objective of the empirical analysis is to test for yardstick competition among school districts in the choice of the income tax. Recall that if $\rho$ is statistically different than zero than this will be taken as evidence of yardstick competition. If yardstick competition is observed, then it is also likely that the estimated coefficients from traditional probit analyses of tax instrument choice are biased. Thus the second goal of the empirical analysis is to see, conditional on their being spatial dependence, how the

\footnotetext{
${ }^{45}$ Non-spatially dependent omitted variable bias is still possible, but since the explanatory variables are the same for the original district as well as the neighbors, most omitted variable bias is likely to be spatially dependent.

${ }^{46}$ There exists a model specifically to correct for spatial error only, the SEM model. Mur and Angulo (2005) show that the SDP model accomplishes the same thing as a SEM model with the advantage that it sorts out individual effects in the disturbance term through the use of the spatially lagged independent variables. The SEM model is more frequently used in the literature; this is primarily because the SDP model is prone to multicollinearity. Fortunately, analysis of the BKW (Belsley, Kuhn, and Welsch 1980) influential observation diagnostics finds that multicollinearity is not a problem.
} 
conclusions from previous studies on fiscal competition and tax instrument choice are changed once spatial dependence is fully taken into account. I first estimate the nonspatial probit model similar to the previous literature and then the SARP and SDP models. Table 3.2 presents the results of these benchmark regressions.

As with regular probit estimation, the coefficients in Table 3.2 are difficult to interpret. The marginal effect of a change in each independent variable in the probability that a school district has an income tax is provided to help with interpretation. In spatial models, the spatial interdependence among observations needs to be corrected for because a change in the explanatory variable has both a direct and indirect effect. ${ }^{47}$ The marginal effects for all spatial models presented in the paper take the 'spatial multiplier effect' into account. The marginal effect of a one standard deviation change in each independent variable are also calculated and provided in Appendix Table 1 for additional ease of interpretation.

The non-spatial probit results in column 1 are nearly identical to the previous literature and are generally consistent with prior expectations. ${ }^{48}$ Business property percentage and mineral property percentage are negatively related to the adoption of an income tax in a statistically significant manner and the property tax price, the presence of a city income tax, and the percentage of agricultural property are statistically significant and positively related to the probability of income tax adoption.

\footnotetext{
${ }^{47}$ See Beron and Vijverberg (2004, 174-175) for further explanation of the interpretation of probit parameters in the spatial context. Basically, the indirect effect arises because a district's decision to adopt an income tax determines how your neighbors feel about an income tax, which in turn affects how the original district feels, which affects the neighboring districts, etc.

${ }^{48}$ This should not be surprising as the only difference between Spry (2005) and the present paper are two observations excluded because of missing data.
} 
Table 3.2

Fis cal Competition and Tax Instrument Choice: Model Comparisons

\begin{tabular}{|c|c|c|c|c|c|c|}
\hline \multicolumn{7}{|c|}{ Dependent variable: Binary Variable Equaling 1 if Taxing Income } \\
\hline Variable & $\begin{array}{c}\text { Non-Spatial } \\
\text { Probit }\end{array}$ & $\begin{array}{c}\text { Marginal } \\
\text { Effect }\end{array}$ & $\begin{array}{l}\text { SARP } \\
\text { Model }\end{array}$ & $\begin{array}{c}\text { Marginal } \\
\text { Effect }\end{array}$ & $\begin{array}{l}\text { SDP } \\
\text { Model }\end{array}$ & $\begin{array}{c}\text { Marginal } \\
\text { Effect }\end{array}$ \\
\hline Constant & $\begin{array}{r}-0.711 \\
(1.267)\end{array}$ & -0.149 & $\begin{array}{l}-0.223 \\
(0.679)\end{array}$ & -0.026 & $\begin{array}{r}-0.847 \\
(1.373)\end{array}$ & -0.236 \\
\hline Within 10 & $\begin{array}{l}-0.093 * * * \\
(2.713)\end{array}$ & -0.019 & $\begin{array}{l}-0.143 * * * \\
(0.047)\end{array}$ & -0.019 & $\begin{array}{r}-0.058 \\
(0.072)\end{array}$ & -0.016 \\
\hline Property Tax Price & $\begin{array}{l}1.264^{* * *} \\
(2.202)\end{array}$ & 0.265 & $\begin{array}{l}1.781^{* * *} \\
(0.686)\end{array}$ & 0.248 & $\begin{array}{l}0.863 * \\
(0.531)\end{array}$ & 0.241 \\
\hline Income Tax Price & $\begin{array}{r}-0.333 \\
(1.291)\end{array}$ & -0.070 & $\begin{array}{l}-0.539 * * * \\
(0.305)\end{array}$ & -0.069 & $\begin{array}{r}-0.091 \\
(0.112)\end{array}$ & -0.025 \\
\hline$\%$ Renters & $\begin{array}{r}-0.010 \\
(0.009)\end{array}$ & -0.002 & $\begin{array}{r}-0.310 \\
(1.334)\end{array}$ & -0.035 & $\begin{array}{r}1.069 \\
(1.552)\end{array}$ & 0.298 \\
\hline City Tax Dummy & $\begin{array}{l}0.598 * * * \\
(3.698)\end{array}$ & 0.126 & $\begin{array}{l}0.713^{* * *} \\
(0.204)\end{array}$ & 0.112 & $\begin{array}{l}0.412 * * \\
(0.238)\end{array}$ & 0.115 \\
\hline$\%$ Senior Citizens & $\begin{array}{l}-1.249 \\
(0.854)\end{array}$ & -0.262 & $\begin{array}{l}-1.783 \\
(1.992)\end{array}$ & -0.352 & $\begin{array}{r}0.197 \\
(2.225)\end{array}$ & 0.055 \\
\hline$\%$ of Agricultural Property & $\begin{array}{l}2.901 * * * \\
(2.861)\end{array}$ & 0.609 & $\begin{array}{l}2.772 * * \\
(1.434)\end{array}$ & 0.502 & $\begin{array}{l}2.321 * \\
(1.558)\end{array}$ & 0.647 \\
\hline$\%$ of Mineral Property & $\begin{array}{l}-53.264 * * * \\
(2.909)\end{array}$ & -11.175 & $\begin{array}{l}-70.338 * * * \\
(26.522)\end{array}$ & -11.496 & $\begin{array}{l}-19.279 \\
(33.232)\end{array}$ & -5.377 \\
\hline$\%$ of Business Property & $\begin{array}{l}-1.818^{* * *} \\
(2.618)\end{array}$ & -0.382 & $\begin{array}{l}-2.357^{* * *} \\
(0.833)\end{array}$ & -0.388 & $\begin{array}{l}-1.775 * * \\
(0.957)\end{array}$ & -0.495 \\
\hline$\%$ of Rural Residents & $\begin{array}{r}0.273 \\
(0.835)\end{array}$ & 0.057 & $\begin{array}{r}0.232 \\
(0.429)\end{array}$ & 0.303 & $\begin{array}{r}0.471 \\
(0.469)\end{array}$ & 0.132 \\
\hline Spatial Lag Term $\rho$ & & & $\begin{array}{l}0.261 * * * \\
(0.061)\end{array}$ & & $\begin{array}{l}0.144 * \\
(0.097)\end{array}$ & \\
\hline Lag \% Agriculture & & & & & $\begin{array}{l}5.537 * * \\
(3.194)\end{array}$ & \\
\hline Other Spatially Lagged X's & & & & & Yes & \\
\hline
\end{tabular}

\begin{tabular}{lrrr}
\hline Number of Observations & 607 & 607 & 607 \\
Psuedo R-squared & 0.23 & 0.77 & 0.65 \\
\hline
\end{tabular}

* indicates significance at the $10 \%$ level, $* *$ at $5 \%$ level and *** at the $1 \%$ level.

In Column 1 the numbers in parentheses are absolute t-statistics. In Columns 2 and 3, posterior standard deviations. Insignificant spatially lagged independent variables supressed for space. 
The results of the SARP model in Column 2 are very similar. The primary exception is that the income tax price is now positive and statistically significant at the one percent level where it was insignificant (but positive) in the non-spatial probit. This could be as a result of the spatial lag correcting for bias, but it is likely the result of the Bayesian approach employed in estimating the SARP model. The Bayesian component of the SARP model attempts to not fit extreme outliers which appear to be driving the insignificant result for income tax price in Column 1. Estimating Column 1 with a nonspatial Bayesian probit confirms this as the income tax price becomes significant. ${ }^{49}$

The spatial lag term $\rho$ in the SARP model has a coefficient of 0.261 and is significantly different than zero, indicating the presence of yardstick competition. The coefficient suggests that the average correlation between a district's choice of an income tax and the weighted average of its neighboring districts choice of an income tax is 0.261 . Unfortunately since the spatial lag term $\rho$ is the coefficient of an unobserved latent variable the marginal effects of neighboring districts use of an income tax on the probability of the home district adopting an income tax cannot be calculated (Rincke 2006).

What about the measure of fiscal competition? The number of school districts within ten miles is negatively and statistically significant related to the probability of using the income tax, appearing to confirm that as the amount of interjurisdictional competition increases uses of the income tax declines. The results from the SARP model in the second column seem to confirm the negative relationship. The number of districts

\footnotetext{
${ }^{49}$ Income tax price seemed to be the only result driven by outliers as all other estimates remain essentially unchanged in the non-spatial Bayesian probit.
} 
in ten miles in negative and significant and the marginal effect of the variable is the same as in the traditional, non-spatial, probit model.

Column 3 presents the results from the SDP model. Recall that spatial Durbin model controls for spatially dependent omitted variable bias by including the weighted average of neighboring districts independent variables as well as the dependent variable. The spatial lag of the percentage of property that is agricultural is significant at the five percent level providing strong evidence of spatial dependence. In addition, the lag of the percentage of mineral property barely misses being statistically significant and is quite large. Controlling for omitted variable bias in the spatially lagged dependent variables greatly reduces the explanatory power of many of the independent variables. Importantly, however, the spatial lag term is still positive and statistically significant at the ten percent level, suggesting that the finding of yardstick competition in the SARP regression was not spurious.

Most notably, failure to control for spatially dependent omitted variable bias most likely gave too much explanatory power to the measure of fiscal competition as the number of districts within ten miles is now statistically insignificant. In addition, the SDP model results suggest that failure to control for spatial dependence in the error term was introducing an upward bias in the size of the parameter estimate. Controlling for spatial dependence reduces the size of the coefficient estimate on the number of districts within ten miles by over 50 percent. These results are consistent with Brasington's (2007) research on interjurisdictional competition and education production. He finds that coefficient estimates on measures of interjurisdictional competition are statistically 
significant in spatial lag models but that those results disappear in once spatial error dependence is taken into account.

The effect of controlling for spatial dependence in the error term can perhaps be seen most prominently in the calculation of marginal effects. For example, not only is mineral property percentage no longer statistically significant, but the marginal effect of the variable is less than half of the estimate in either the SARP model or the regular probit. Appendix Table 2 provides a calculation of the marginal effect a one standard deviation change in the a school districts mineral property percentage is estimated to reduce the probability of adopting an income tax by two and a half percentage points, half of what is predicted in the SARP or standard probit models (Appendix 2). The importance of not relying solely on parameter coefficients can be seen in the case of the business property percentage. The estimated parameter coefficient is smaller in the SDP regression that in the SARP regression, but the marginal effect is now larger. Looking at Appendix 2, we can see that a one standard deviation change in the percentage of business property in a school district will reduce the probability that a district will use the income tax by 7.5 percent, an estimate over 1.5 percentage points higher than similar calculation from the SARP model.

Other items of interest are that the income tax price is no longer statistically significant once spatial error dependence is taken into account with the SDP model. The marginal effect of a one standard deviation change in the income tax price is reduced by nearly two-thirds over the other two models. Although the variables are not significant, it should be noted that the percentage of renters and the percentage of senior citizens in a 
school district both changed signs in the SDP model with both now being positive, which is what theory would predict.

The finding that fiscal competition does not matter once spatial dependence is taken into account might be a function of how the degree of interjurisdictional competition is defined. In addition to the number of school districts within ten miles, Spry (2005) also estimates the number of districts within 12 and 15 miles. Another definition of fiscal competition frequently used in the literature is a Herfindahl index of market concentration (see, for example, Borland and Howsen (1996) or Hoxby (2000a)). Here the Herfindahl index takes the form of:

$$
H E R F=1-\sum_{j=1}^{J} S_{j m}^{2}
$$

where $s_{j m}$ is equal to district j's share of school enrollment in county m. Using this formulation a 'monopoly' county will have a value of 0 and as perfectly competitive county would have a score of one.

Table 3.3 presents the results of these alternative regressions employing the Bayesian SDP model and the same specifications as in Table 3.2 but substituting these three alternative definitions of interjurisdictional competition for the number of districts within ten miles. As can be seen in the table, changing the definition of fiscal competition does not change the results. In all three specifications the new variables are statistically insignificant. In the case of the within 12 and within 15 miles measures, the marginal effect is smaller compared to the within 10 mile measures as well. This is to be expected given the usual assumption that farther away districts would be weaker substitutes. 
Table 3.3

Fiscal Competition and Tax Instrument Choice: Robustness Checks

\begin{tabular}{|c|c|c|c|c|c|c|}
\hline \multicolumn{7}{|c|}{ Dependent variable: Binary Variable Equaling 1 if Taxing Income } \\
\hline Variable & SDP Model & $\begin{array}{c}\text { Marginal } \\
\text { Effect }\end{array}$ & SDP Model & $\begin{array}{c}\text { Marginal } \\
\text { Effect }\end{array}$ & SDP Model & $\begin{array}{c}\text { Marginal } \\
\text { Effect }\end{array}$ \\
\hline Constant & $\begin{array}{r}-1.166 \\
(1.315)\end{array}$ & -0.297 & $\begin{array}{r}-0.700 \\
(1.493)\end{array}$ & -0.217 & $\begin{array}{r}0.560 \\
(1.932)\end{array}$ & 0.142 \\
\hline Within 12 & $\begin{array}{r}-0.005 \\
(0.070)\end{array}$ & -0.001 & & & & \\
\hline Within 15 & & & $\begin{array}{r}-0.004 \\
(0.052)\end{array}$ & -0.001 & & \\
\hline Herfindahl Index & & & & & $\begin{array}{r}-0.252 \\
(0.815)\end{array}$ & -0.064 \\
\hline Property Tax Price & $\begin{array}{l}0.904 * \\
(0.688)\end{array}$ & 0.230 & $\begin{array}{c}0.823 * \\
(0.768)\end{array}$ & 0.255 & $\begin{array}{c}0.851 * \\
(0.565)\end{array}$ & 0.216 \\
\hline Income Tax Price & $\begin{array}{l}-0.222 * \\
(0.387)\end{array}$ & -0.056 & $\begin{array}{r}-0.176 \\
(0.472)\end{array}$ & -0.055 & $\begin{array}{l}-0.112 \\
(0.138)\end{array}$ & -0.029 \\
\hline$\%$ Renters & $\begin{array}{r}1.308 \\
(1.520)\end{array}$ & 0.333 & $\begin{array}{r}1.007 \\
(1.618)\end{array}$ & 0.312 & $\begin{array}{r}0.943 \\
(1.495)\end{array}$ & 0.239 \\
\hline City Tax Dummy & $\begin{array}{l}0.437 \text { ** } \\
(0.231)\end{array}$ & 0.111 & $\begin{array}{l}0.4611^{* *} \\
(0.240)\end{array}$ & 0.143 & $\begin{array}{l}0.447^{* *} \\
(0.232)\end{array}$ & 0.113 \\
\hline$\%$ Senior Citizens & $\begin{array}{l}-0.600 \\
(2.309)\end{array}$ & -0.153 & $\begin{array}{l}-0.136 \\
(2.36)\end{array}$ & -0.042 & $\begin{array}{r}0.014 \\
(2.341)\end{array}$ & 0.003 \\
\hline$\%$ of Agricultural Property & $\begin{array}{l}2.473 * * \\
(1.531)\end{array}$ & 0.629 & $\begin{array}{c}2.399 * \\
(1.476)\end{array}$ & 0.742 & $\begin{array}{c}2.355 * \\
(1.458)\end{array}$ & 0.597 \\
\hline$\%$ of Mineral Property & $\begin{array}{r}-14.604 \\
(30.232)\end{array}$ & -3.717 & $\begin{array}{l}-19.197 \\
(32.124)\end{array}$ & -5.939 & $\begin{array}{c}-24.593 \\
(32.067)\end{array}$ & -6.235 \\
\hline$\%$ of Business Property & $\begin{array}{l}-1.840 * * \\
(0.918)\end{array}$ & -0.468 & $\begin{array}{l}-2.056 * * \\
(0.984)\end{array}$ & -0.636 & $\begin{array}{l}-1.861 * * \\
(0.901)\end{array}$ & -0.472 \\
\hline$\%$ of Rural Residents & $\begin{array}{r}0.570 \\
(0.474)\end{array}$ & 0.145 & $\begin{array}{r}0.484 \\
(0.490)\end{array}$ & 0.150 & $\begin{array}{r}0.448 \\
(0.443)\end{array}$ & 0.114 \\
\hline Spatial Lag Term $\rho$ & $\begin{array}{c}0.145 \text { * } \\
(0.096)\end{array}$ & & $\begin{array}{c}0.161 * \\
(0.098)\end{array}$ & & $\begin{array}{c}0.140 * \\
(0.096)\end{array}$ & \\
\hline Spatially Lagged X's & Yes & & Yes & & Yes & \\
\hline Number of Observations & 607 & & 607 & & 607 & \\
\hline Psuedo R-squared & 0.70 & & 0.69 & & 0.68 & \\
\hline
\end{tabular}


Even if these new measures of fiscal competition were statistically significant, a one standard deviation in each of the measures is estimated to have an extremely small effect on the probability of adopting an income tax - between six-tenths for the number of districts within 12 miles and one percent for the Herfindahl measure.

Thus there appears to be little evidence that fiscal competition plays a role in the tax structure of local school districts once spatial dependence is properly addressed. ${ }^{50} \mathrm{In}$ addition, the spatial lag term is statistically significant in all three specifications, with spatial lag estimates ranging from 0.140 to 0.161 , providing further evidence to support the finding of yardstick competition in the choice of an income tax.

\subsection{Conclusion}

This paper finds evidence of yardstick competition in the choice of Ohio school districts to adopt an income tax. The parameter on the spatial lag term estimating the degree of yardstick competition varied from 0.140 to 0.161 across the appropriate specifications. These findings suggest that the probability of passing an income tax is higher in school districts whose neighbors already utilize the income tax.

The influence of fiscal competition on the choice among property and income taxes is the focus of recent empirical research by Spry (2005). He finds a negative relationship between the degree of interjurisdictional competition and the use of an income tax by Ohio school districts. After controlling for spatial dependence in the

\footnotetext{
${ }^{50}$ In unreported regressions available from the author, I utilize the weight matrix used by Brasington (2007) that measures a school district's five nearest neighbors. The findings are qualitatively similar using this alternative weighting matrix.
} 
dependent variable, independent variables, and the error term I find that no statistically significant relationship exists.

In terms of policy, the findings are straightforward. The degree of interjurisdictional competition is not what is preventing the use of the income tax in Ohio school districts. A 'race to the bottom' form of tax competition where school districts in competitive metropolitan areas compete for mobile high-income taxpayers can thus be ruled out. Instead, the reasons why school districts in Ohio do not adopt an income tax appear to be rational responses to the preferences of the median voter. If there is a lot of business property in the district, voters prefer the property tax to the income tax, other things equal, because of tax burden exportation. In areas with a lot of agricultural property, voters prefer to adopt an income tax, since farmers usually own more property than the average citizen but realize less income.

More importantly, my findings are consistent with Brasington (2007) who first showed that interjurisdictional effects are biased when spatial dependence is not accounted for. Researchers looking into the effect of interjurisdictional competition on various outcomes need to account for spatial dependence among governments in order to avoid having biased, inefficient, and inconsistent parameter estimates. In addition to adding to the explanatory power of the models, the use of spatial econometrics also led to significantly more accurate parameter estimates. 


\section{Chapter 4 \\ Institutions, Capital, and Growth}

\subsection{Introduction ${ }^{51}$}

The causes of economic development have been studied before Adam Smith made his inquiry into the causes of the wealth of nations. As a field of study, however, economic development did not really exist until after World War II (Arndt 1997). The first development economists focused primarily on the accumulation of physical capital as the driving force in economic growth. ${ }^{52}$ For example, Paul Rosenstein-Rodan, Sir Arthur Lewis, and Walt Rostow all argued that developing countries suffered from a "poverty trap' where they could not afford to save enough to accumulate the necessary amounts of human capital to grow (Easterly 2006a). This focus on the accumulation of physical capital provided the intellectual impetus for the large sums of foreign aid provided to developing countries by international aid agencies post World War II because aid was seen as being crucial to giving poor nations the physical capital they needed to break out of the 'poverty trap.' The notion that developing countries are in a poverty trap that prevents them from accumulating physical capital is still alive today, both in the actions of the World Bank and IMF as well as in the research of economists such as Jeffrey Sachs. ${ }^{53}$

\footnotetext{
51 This essay draws heavily from a working paper with Russell S. Sobel titled "Institutions, Capital, and Growth."

52 One notable exception is Peter Bauer $(1948 ; 1954$; 1957) who viewed the accumulation of capital as an outcome of successful economic performance, not an input.

${ }^{53}$ For example, in his book The End of Poverty, Jeffrey Sachs (2005, 56-57) says "This is the main reason why the poorest of the poor are most prone to becoming trapped with low or negative economic growth rates. They are too poor to save for the future and thereby accumulate
} 
In the 1960s and 70s, the pioneering work of Schultz (1961) and Becker (1964) on human capital caused development economists to augment their standard economic growth models to allow for human capital investment to play a role. Early research into the effects of formal education on economic growth found that education seemed to explain a significant portion of economic growth (Hall 2000). These findings led development economists to focus on human capital as a primary factor of production throughout the 1980s and 1990s (Coyne and Boettke 2006). International development organizations such as the World Bank encouraged high levels of government investment in schooling in an attempt to increase human capital levels. As a result of these efforts, there was a tremendous expansion of schooling in nearly all developing countries (Easterly 2001). According to Pritchett (2001), since 1960 primary enrollments in developing countries increased from 66 to 100 percent and secondary enrollments rose from 14 to 40 percent.

There is little evidence to suggest that efforts to increase capital levels in developing countries, especially in Africa, have been successful in generating growth. Good historical data on public investment in capital is available for 22 African countries since 1970. From 1970-1994, those countries received $\$ 187$ billion in aid and spent $\$ 342$ billion on public investment, only to achieve zero per capita growth (Easterly 2006b). The same can be said of the increases in formal schooling stimulated, in part, by foreign aid. Easterly (2001) details how sub-Saharan African countries had larger increases in schooling than any other region since 1960 . Yet these countries remained mired in poverty while Asian 'tigers' like South Korea and Taiwan had smaller increases in

the capital that could pull them out of their current misery." For more on the revival of the 'Big Push' and 'poverty trap' theories of development, see Easterly (2006b). 
education levels but flourished economically. In cross-country growth regressions, Pritchett (2001) finds no relationship between increases education and increases in output per worker. Similarly, Gwartney, Holcombe and Lawson (2004) find that the growth of human capital per worker is not related to per capita GDP growth. ${ }^{54}$

The macroeconomic evidence is somewhat paradoxical because it is contrary to the microeconomic evidence that increases in physical and human capital increase individual productivity and remuneration. After all, it would seem that summing all individual positives within a country should aggregate to a social positive. Yet it many countries this is not the case. In this paper I put forth a potential answer to this question by considering the institutional context of capital accumulation. My thesis is that the societal payoffs to improvements in the levels of both physical and human capital are largely dependent on the institutional context in which those investments occur. ${ }^{55}$

In countries with good institutions - where the social, political, and legal rules provide for secure property rights, unbiased contract enforcement, and reliance on market prices and profits and losses to guide economic activity - investments in capital are both privately beneficial to individuals and also create a positive return for society as a whole. In countries with poor institutions, however, the higher returns to investments in rent-

\footnotetext{
${ }^{54}$ There is a large body of empirical literature showing that initial education levels matter for economic growth (Barro 1991; Barro and Sala-i-Martin 1995). Pritchett $(2001,381)$ argues that these papers are misspecified as growth rates are stationary and the education stock is nonstationary and globally increasing. A stable relationship is thus not possible between education and growth when formulated in that manner. In addition, such a formulation cannot explain negative growth rates or the fact that fact that the initial level of education has been rising for over forty years in sub-Saharan Africa but growth has stagnated or declined.

${ }^{55}$ The idea that additional education, in some instances, might actually yield low or negative social returns is not new. In Free to Choose: A Personal Statement, Milton and Rose Friedman $(1980,34)$ suggested that higher education might lead to the disruption of the social order and political institutions. Griliches (1997) suggests in a footnote that the effect of education on productivity might be muted in countries where most educated individuals end up working within governments not known for productivity.
} 
seeking activities that plunder the wealth of others, through lobbying and lawsuit abuse, for example - draw significant resources into these privately beneficial, but socially unproductive activities. Investments in education produce more lobbyists, politicians, and lawyers, rather than engineers and scientists. ${ }^{56}$ In the terminology of Baumol (1990), the allocation of entrepreneurial efforts between productive, positive-sum activities and unproductive or even destructive, negative-sum activities in a society is a function of the returns to these alternative activities that are determined by the quality of a country's legal and political institutions.

There are two reasons why capital investments in countries with poor institutions should generate a lower social return. I term these the 'allocation effect' and the 'productivity effect'. The allocation effect is the process described above, in which poor institutions draw a large proportion of new capital investments into socially unproductive activities to plunder wealth. Because of this fewer resources are allocated toward productive activities that generate additions to the country's economic output. The second, productivity effect relates to the ability of a country's economy to properly allocate additional capital investments to their highest valued use. When collective decision making and the political process are used to control prices, regulate business activities, and enact selective taxes and subsidies that distort the market profit and loss mechanism, capital investments will simply not be allocated as efficiently toward their highest valued use. Combined, the productivity and allocation effects result in lower, and

\footnotetext{
${ }^{56}$ There is a clear parallel between our argument and that of Murphy, Shleifer, and Vishny (1991) who take the proportion of students enrolled in law as representative of the societal payoffs to rent-seeking. They find that countries with a higher proportion of law students have slower growth than countries and countries with a higher percentage of students studying engineering grow slower.
} 
potentially negative, social returns to both physical and human capital investment in countries with poor institutions.

\subsection{Institutions, Capital, and Growth of Output per Worker}

The conventional perspective on the marginal effect of increases in physical and human capital on economic growth is that they have the same marginal effect regardless of the level of institutional quality. Figure 4.1 illustrates this view. The figure shows the marginal effect of a change in capital per worker on the change in output per worker conditional on the level of institutional quality. From this perspective, an additional unit of capital has the same impact on economic growth whether the country is in a good institutional environment or a poor one. To put it the context of human capital, an addition year of education in the Democratic Republic of the Congo would have the same effect on the growth of output per worker as a year in Australia.

My hypothesis is that this view is incorrect because it ignores the impact of institutional quality on the productivity and allocation of labor. An additional year of education in the Democratic Republic of the Congo is not the same as an additional year of education in Australia because of the opportunities provided by the overall institutional environment. ${ }^{57}$ The best opportunities for more educated individuals in countries with low-quality institutions are more likely to be zero-or-negative sum, such as working in the government bureaucracy. When the institutional environment is 'bad', increases in

\footnotetext{
${ }^{57}$ The years of education are also different in that they might come at different levels (primary vs. secondary) and that the quality of the education surely differs. As described later, the first problem is dealt with in how measures of education growth are constructed. Correction of the second problem is hampered by the lack of systematic test score data for a large number of countries.
} 
education levels will be less socially productive than in countries with a 'good' institutional environment. While individuals will always choose the occupation that gives them the highest personal return, good institutions create a correspondence between positive personal and positive social returns.

\section{Figure 4.1}

\section{Marginal Effect of Capital on Output per Worker: Conventional View}

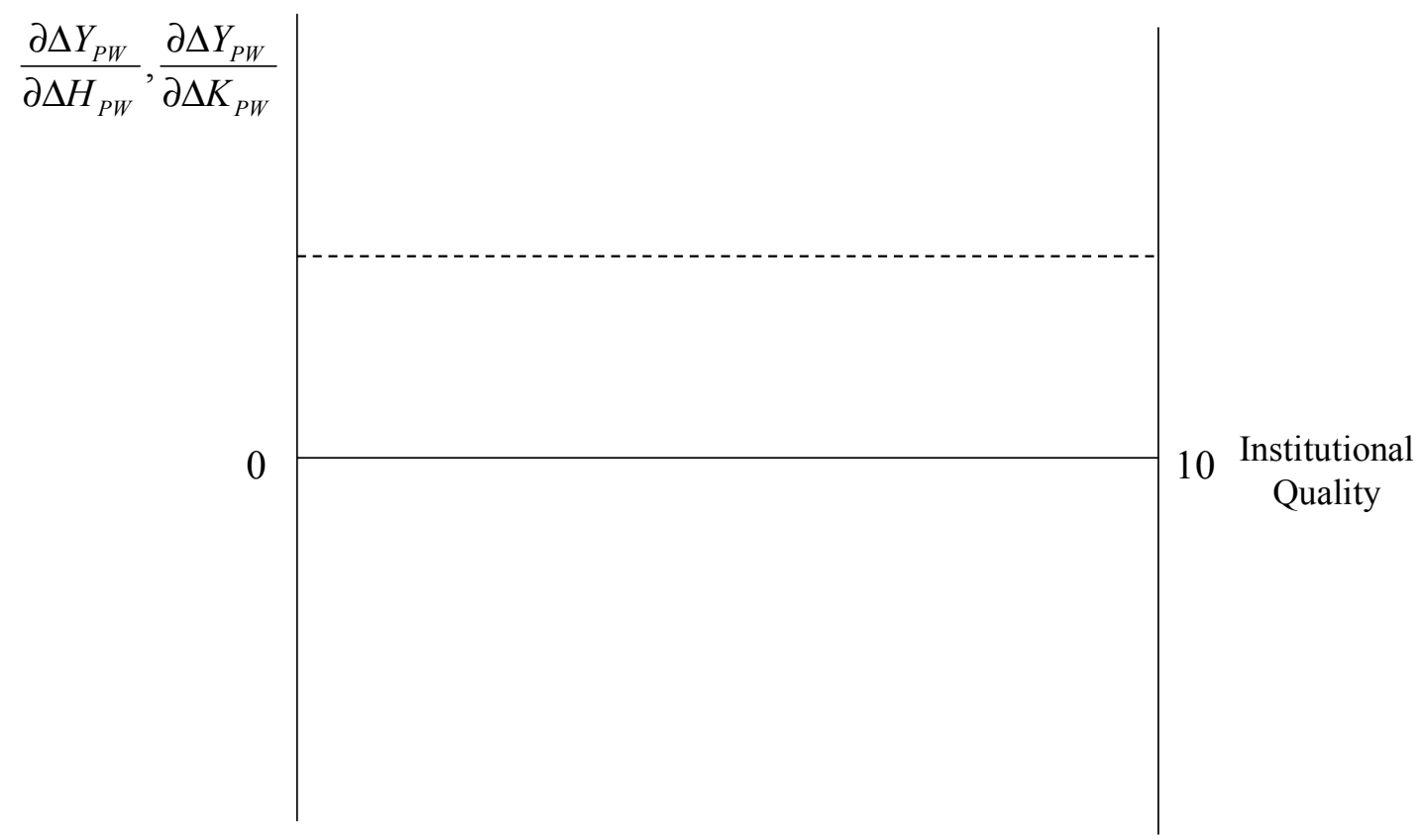

In the long-run, the higher payoffs to public sector activity distort the choices individuals make in the types of education to acquire. Thus in a society where the payoffs to the private sector are low because of poor institutions but payoffs to the public sector are high (also because of poor institutions), individuals will tend to invest in human capital more valued by the public sector. For example, Nobel Laureate Sir Arthur Lewis discusses in his Nobel Prize lecture how he wanted to be an engineer but could not find employment in St. Lucie as an engineer because of discrimination, thus he went into 
business studies with the goal of working in the civil service or private sector (Lewis 1992). While both the public and private sector employ engineers, the issue is that in countries with poor institutional environments the payoffs to being a private sector engineer will be lower and thus we will get fewer engineers and the ones we do have will be less alert to positive-sum entrepreneurial opportunities.

Countries with bad institutions have more zero or negative-sum opportunities and thus the marginal effect of more education could be negative if enough of the additional education goes into negative-sum activities. Not only are resources being removed from production in order to increase education levels (in terms of expenditures on education but also opportunity costs), but if educated individuals move into rent-seeking the societal payoffs from their education will be negative. At some level of institutional quality, however, the rewards to positive-sum activities begin to outweigh the rewards to zero and negative-sum activities and the marginal effect of human capital increases on growth becomes positive.

Figure 4.2 illustrates this proposed relationship. The marginal effect of an increase in capital is negative when institutional quality is 'zero.' While all societies have some level of formal or informal institutions, counties like present-day Somalia, Rwanda or Venezuela would be examples of countries that have extremely low levels of institutional quality according to most measures. At some break-even level of institutional quality the allocation of resources between sectors of the economy is balanced so that net additions to capital neither add to nor diminish output per worker. As institutional quality rises beyond that break-even point, the additions to capital flow to the productive sectors of the economy and have a positive contribution to output per worker. 
This view of the role of institutions in channeling increases in capital towards sociallyproductive areas of the economy helps to explain why public investment in human and physical capital have not uniformly led to increases in output per worker in the developing world.

Figure 4.2

Marginal Effect of Capital on Output per Worker: Institutional View

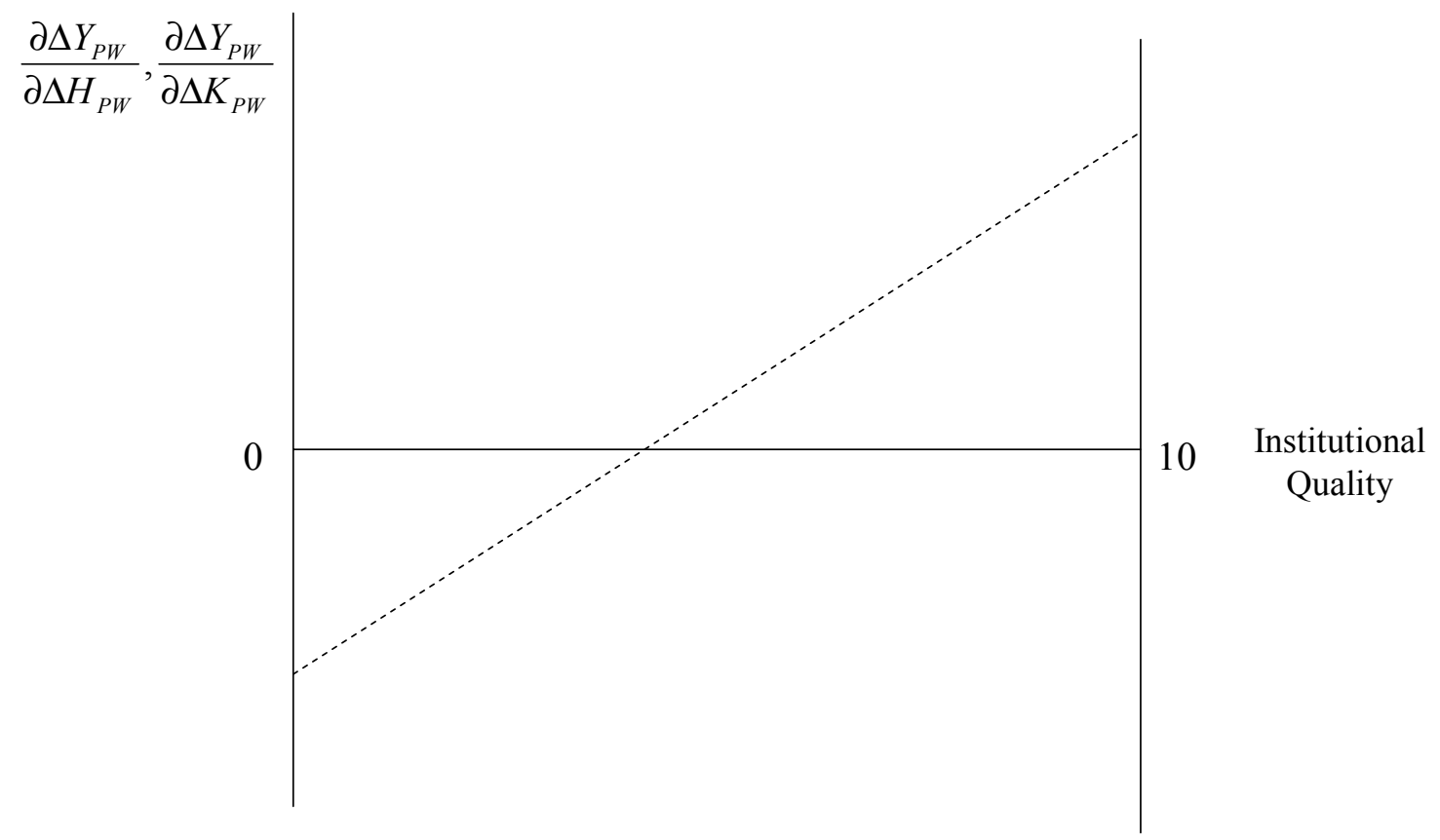

\subsection{Theoretical Model}

In this section I augment a macroeconomic growth model to incorporate the impact of institutional quality. Mankiw, Romer, and Weil (1992) first augmented the standard Solow (1956) growth model to include human capital. They consider a standard aggregate production function given by: 


$$
Y_{t}=A_{t} K_{t}^{\alpha_{1}} H_{t}^{\alpha_{2}} L_{t}^{\alpha_{3}}
$$

where $\mathrm{Y}$ is output, $\mathrm{A}$ is the level of technology that augments physical capital $(\mathrm{K})$, human capital $(\mathrm{H})$, and labor $(\mathrm{L})$. The production function exhibits the standard assumption of constant returns to scale $\left(\alpha_{1}+\alpha_{2}+\alpha_{3}=1\right)$. Dividing through by L puts (1) in per worker terms:

$$
y_{t}=A_{t} h_{t}^{\alpha_{1}} k_{t}^{\alpha_{2}}
$$

This traditional model implicitly assumes an underlying set of good institutions. In our model, the quality of institutions affects output through the effect that institutions have on the productivity of human and physical capital. Thus I specify the technology parameter as:

$$
A_{t}=A_{0} h_{t}^{\beta_{1}\left(I-I^{*}\right)} k_{t}^{\beta_{2}\left(I-I^{*}\right)}
$$

where $A_{0}$ represents the basic level of technology, $I^{*}$ represents the ideal institutions implicitly assumed in the traditional growth model, and $I$ is the country's current level of institutional quality. Thus, $I-I^{*}$ measures the degree to which the country's institutions fall short of ideal conditions. When $I=I^{*}$, the model reduces to its standard form in the previous literature.

Substituting (3) into (2) yields:

$$
y_{t}=A_{0} h_{t}^{\beta_{1}\left(I-I^{*}\right)} k_{t}^{\beta_{2}\left(I-I^{*}\right)} h_{t}^{\alpha_{1}} k_{t}^{\alpha_{2}}
$$

Rearranging:

$$
y_{t}=A_{0} h_{t}^{\alpha_{1}+\beta_{1}\left(I-I^{*}\right)} k_{t}^{\alpha_{2}+\beta_{2}\left(I-I^{*}\right)}
$$

Taking logs:

$$
\ln y_{t}=\ln A_{0}+\left[\alpha_{1}+\beta_{1}\left(I-I^{*}\right)\right] \ln h_{t}+\left[\alpha_{2}+\beta_{2}\left(I-I^{*}\right)\right] \ln k_{t}
$$


Here I follow Pritchett (2001) in focusing on explaining the growth of output per worker using the growth of physical and human capital per worker. I do this by taking differences, which gives the growth rate of output as:

$$
\hat{y}_{t}=\hat{A}_{0}+\left[\alpha_{1}+\beta_{1}\left(I-I^{*}\right)\right] \hat{h}_{t}+\left[\alpha_{2}+\beta_{2}\left(I-I^{*}\right)\right] \hat{k}_{t}
$$

where ${ }^{\wedge}$ indicates denotes a growth rate. Simplifying:

$$
\hat{y}_{t}=\hat{A}_{0}+\left(\alpha_{1}-\beta_{1} I *\right) \hat{h}_{t}+\beta_{1} I \hat{h}_{t}+\left(\alpha_{2}-\beta_{2} I *\right) \hat{k}_{t}+\beta_{2} \hat{l} \hat{k}_{t}
$$

Defining $\delta_{i}=\left(\alpha_{i}-\beta_{i} I^{*}\right)$ and $\alpha_{0}=\hat{A}_{t}$, and adding an error term, $\varepsilon_{t}$, yields our equation to be estimated:

$$
\hat{y}_{t}=\alpha_{0}+\delta_{1} \hat{h}_{t}+\beta_{1} I \hat{h}_{t}+\delta_{2} \hat{k}_{t}+\beta_{2} \hat{k}_{t}+\varepsilon_{\mathrm{t}}
$$

Equation (9) is the primary equation I use to test the impact of institutions on the productivity of physical and human capital. Of interest are the coefficient estimates for $\delta_{1}, \delta_{2}, \beta_{1}$, and $\beta_{2}$. $\delta_{1}$, and $\delta_{2}$ measure the return to human and physical capital investments in a country with the worst possible institutional quality (the left $y$-axis intercept value in Figure 2), while $\beta_{1}$, and $\beta_{2}$ are the slopes of the respective lines in the figures, showing an increasing social return to these capital investments as the country's institutional quality improves to the ideal level for a well-functioning market economy.

\subsection{Data and Empirical Approach}

My initial analysis covers a cross-section of 96 countries for the years 1980-2000. I obtain data on real output per worker from Baier, Dwyer and Tamura (2006) and calculate the cumulative growth of output per worker from 1980 to 2000 . The included countries are a comprehensive mixture of developed and developing nations from all 
regions, mitigating any concerns over sample selection bias that can be an issue in crosscountry growth studies (De Long 1988). A full list of the countries is included in Appendix Table 3. The average country in our sample had a 16.4 percent increase in output per worker increase over the period, with Cyprus having the top growth rate of 276 percent and the Republic of Congo seeing output per worker fall by 79 percent.

I measure institutional quality using an index of the 'risk of expropriation' within a country. Produced by the Political Risk Services (PRS) Group (2007) and published in the International Country Risk Guide, these data were first used as a measure of institutional quality by Knack and Keefer (1995) and more recently by Acemoglu, Johnson, and Robinson (2001a; 2001b) and Glaeser et al. (2005). The PRS Groups annually grades each country on the risk of confiscation or forced nationalization of property, using a zero-to-ten scale. A score of zero is consistent with a high risk of property expropriation and a country with a score of 10 would represent an extremely low risk of expropriation. I feel this measure of institutions is most consistent with Acemoglu and Johnson's (2005) finding that property-right institutions are what matter for long-run growth. While concerns have been raised over 'outcome' measures of institutions (Glaeser et al. 2005), written rules ostensibly designed to protect citizens from government are useless unless the politically powerful are willing to commit to obeying the rules (Boettke 2001, 191-265).

I follow convention and use the average risk of expropriation within a country over the period in question. ${ }^{58}$ The average country in the sample had a score of 7.3. The country with the lowest risk of expropriation was Switzerland with an average risk of expropriation of 9.98, while the country with the greatest average risk of expropriation

${ }^{58}$ Specifically, the variable is the average from 1982-1997, obtained from Glaeser et al. (2005). 
was the Democratic Republic of the Congo with a score of 3.71. The Democratic Republic of the Congo having the highest risk of expropriation is illustrative of the problem that exists in trying to use input measures of institutions such as constitutions instead of output measures, since the recent switch from dictatorship to constitutional democracy has not seemed to reduce expropriation of private property (Boettke and Leeson 2007).

Our measure of education is average years of schooling per worker and it is obtained from Baier, Dwyer, and Tamura (2006). They calculate the average number of years of schooling per worker from primary, secondary, and higher education enrollment figures using the perpetual inventory method. The perpetual inventory method uses census-survey figures on attainment by age as a measure of the stock of schooling and then updates the stock using lagged enrollment figures. I use their estimates of average schooling per worker in 1980 and 2000 to calculate the change in schooling per worker by country from 1980-2000. Our measure of the change in physical capital per worker from 1980 to 2000 is also obtained from Baier, Dwyer, and Tamura (2006). They use the perpetual inventory method to calculate the physical capital stock per worker using annual investment data from the Summers and Heston (2000) data set and assuming 7 percent annual depreciation.

These data on a cross-section of 96 countries allow us to begin addressing the relationship between institutions and the productivity of human and physical capital. Our equation to be estimated using Ordinary Least Squares (OLS) is obtained from the estimating equation derived in section 3 :

$$
\hat{y}_{t}=\alpha_{0}+\delta_{1} \hat{h}_{t}+\beta_{1} I \hat{h}_{t}+\delta_{2} \hat{k}_{t}+\beta_{2} I \hat{k}_{t}+\varepsilon_{\mathrm{t}}
$$


where $\hat{y}_{t}$ is the cumulative growth rate from 1980 to $2000, \alpha_{0}$ is a constant term, $\hat{h}_{t}$ is the change in schooling over that period, and $\hat{k}_{t}$ is the change in physical capital. The interaction terms, $I \hat{h}_{t}$ and $I \hat{k}_{t}$ measures how economic growth in different countries might respond differently to changes in human and physical capital depending upon the level of institutions, measured here by the average level of expropriation risk during the period.

In addition to this basic model, I provide several robustness checks that consider additional explanatory variables. For example, a prominent strain of the development literature, most notably associated with Jeffrey Sachs (2003), argues that geographic factors play an extremely important role the economic development of nations. From Gallup, Sachs, and Mellinger (1999) I obtain three geographic variables that might influence the rate of economic growth. The first geographic variable is the minimum air distance a country is from the core markets of Rotterdam, New York, or Tokyo. The hypothesis is that the farther a country is from one of these core markets, the more costly it is for the country to engage in international trade. Reduced trade will, in turn, reduce gains from the division of labor, economies of scale, and specialization. The second geographic variable, the percentage of a country's population living within 100 kilometers of an ocean, also attempts to measures the degree to which it is costly for the citizens of a country to engage in international trade. A high percentage of a country's population with access to an ocean coastline should exert a positive impact on economic growth.

Finally, a country located in a tropical climate might have low rates of economic growth because a hot and humid climate reduces the productivity of labor. This can occur 
directly through work effort or indirectly through health. The prevalence of malaria in tropical climates provides one channel through which tropical climate can affect health and, indirectly, the productivity of labor. To capture the effect of tropical climate on growth, I employ a third geographic variable measuring the proportion of a country located in the tropics as an explanatory variable, with the tropics defined as the area located between the Tropic of Cancer (23.5 latitude North) and Tropic of Capricorn (23.5 latitude South). These geographic variables are employed both in the baseline empirical analysis in Section 4.6 as well as the sensitivity analysis in Section 4.7.

\subsection{A First Look}

Before proceeding to the regression analysis, I provide some evidence for the proposition that the effect of investment in capital depends on the institutional environment using the raw data. To get an idea of how the returns to schooling differ by institutional quality, I broke down countries into two groups: those with the lowest risk of expropriation and those with the highest risk. I split the sample of 96 countries into two groups based on their average risk of expropriation score, with countries below the median score of 7.06 being defined as 'high risk' and those above defined as 'low risk.' Figure 4.3 shows the relationship between changes in schooling per worker and growth in output per worker for these different groups.

Among countries with the lowest risk of expropriation, countries with schooling growth above 50 percent from 1980-2000 grew slightly faster than countries where schooling growth was below 50 percent. For countries with the highest risk of expropriation, however, the exact opposite was the case. While all countries with poor 
protection of property rights saw negative real growth during this period, those countries with schooling growth below 50 percent had an average growth of output per worker of negative 3.7 percent compared to negative 25.3 percent for countries with schooling growth above 50 percent. Clearly, countries with bad institutions did poorly over this time period; however, those countries with the largest increases in education did the worst.

Figure 4.3

The Stratification of the Returns to Schooling by Risk of Expropriation

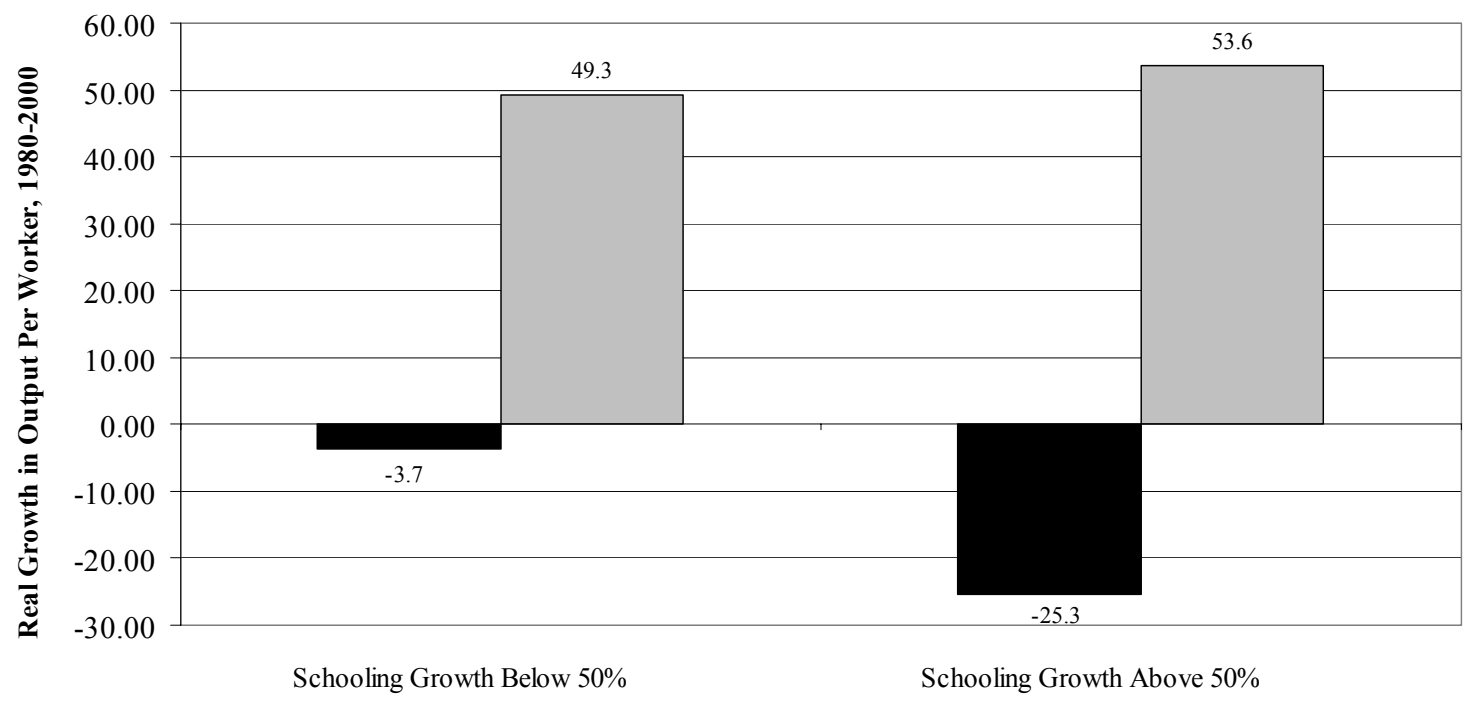

- Highest Risk $\quad \square$ Lowest Risk

\subsection{Empirical Results}

Table 4.1 presents our regression results that examine the effect of institutions on the impact of human and physical capital growth on a country's rate of economic growth. Column 1 is the baseline regression consistent with equation (9) derived in Section 4.3. The model fits the data well, explaining 56 percent of the variation in the change in 
output per worker between 1980 and 2000. The coefficients on both interaction terms are positive and statistically significant, while the coefficients on the change in physical and the change in human capital are negative and significant. These results are consistent with our hypothesis that changes in physical and human capital only have a positive effect on the rate of economic growth where strong property-rights institutions are in place. In countries with strong institutions, increases in human and physical capital have a larger effect on economic growth rates than in countries with bad institutions.

Table 4.1

The Determinants of Economic Growth

\begin{tabular}{|c|c|c|c|c|}
\hline \multicolumn{5}{|c|}{ Dependent Variable: Growth of Output per Worker, 1980-2000 } \\
\hline Independent Variables & 1 & 2 & 3 & 4 \\
\hline \multirow[t]{2}{*}{ Constant } & -1.17 & 0.96 & 6.17 & 9.91 \\
\hline & $(0.28)$ & $(0.11)$ & $(0.81)$ & $(1.54)$ \\
\hline Growth of Schooling Per Worker & $-0.719 * * *$ & $-0.734 * * *$ & $-0.637 * * *$ & $-0.362 *$ \\
\hline (Baier et al.), 1980-2000 & $(3.59)$ & $(3.64)$ & $(3.13)$ & $(1.67)$ \\
\hline Growth of Physical Capital Per & $-0.789 * * *$ & $-0.793 * * *$ & $-0.735 * * *$ & $-0.762 * * *$ \\
\hline Worker, 1980-2000 & $(8.05)$ & $(8.10)$ & $(6.56)$ & $(7.62)$ \\
\hline Growth of Schooling Per Worker $\times$ & $0.098 * * *$ & $0.100 * * *$ & $0.087 * * *$ & $0.050 *$ \\
\hline Risk of Expropriation & $(3.60)$ & (3.64) & $(3.14)$ & $(1.68)$ \\
\hline Growth of Physical Capital Per & $0.161 * * *$ & $0.162 * * *$ & $0.153 * * *$ & $0.158 * * *$ \\
\hline Worker $\times$ Risk of Expropriation & $(10.83)$ & $(10.73)$ & $(9.63)$ & $(11.65)$ \\
\hline Percentage of Population within & & -0.042 & & \\
\hline $100 \mathrm{~km}$ of Coast & & $(0.34)$ & & \\
\hline Air Distance from Major Trading & & & -0.0018 & \\
\hline Centers & & & $(1.15)$ & \\
\hline Percentage of Land Area Located & & & & $-0.243 * *$ \\
\hline in Tropics & & & & $(2.54)$ \\
\hline Number of Observations & 96 & 96 & 96 & 96 \\
\hline Adj. r-squared & 0.56 & 0.56 & 0.56 & 0.59 \\
\hline
\end{tabular}

Absolute value of heteroskedasticity-corrected t-statistics in parentheses.

* indicates significance at the $10 \%$ level, ** at $5 \%$ level and *** at the $1 \%$ level. 
In Columns 2, 3, and 4 of Table $1 \mathrm{I}$ included additional geographic variables thought to impact economic growth. Importantly, the inclusion of these variables does not qualitatively change the results of our basic regression. In all three additional columns, the signs and coefficients on each of the variables are very similar to those in Column 1 . One notable exception is in Column 4, where the coefficients on human and physical capital per worker variables were reduced in magnitude. Note, however, that the coefficients on each of the interaction terms are very similar to the coefficients in the previous regressions suggesting that good institutions still channel physical and human capital to productive ends in tropical environments.

The only geographic variable to add any explanatory power to the model is the percentage of the land area in the tropics. A country entirely located in the tropics is expected to have a cumulative growth rate 24.3 percentage points lower from 1980-2000 than a country with none of its area in the tropics. The other two geographic variables are not statistically or economically meaningful, with the percentage of the population within 100 kilometers even having the opposite sign of what is expected.

In Figure 4.4 I take the coefficients from Column 1 above and put them in the context of the framework put forth in Figure 4.2. The negative left y-axis intercept values of -0.719 and -0.789 for human and physical capital respectively show the socially negative returns to investments in these areas in countries scoring the worst possible value on the risk of expropriation measure (remember this index is increasing in property rights protection). The intercept values along the right $y$-axis show the return in a country with ideal institutional quality. I find that the 'break-even' point is a risk of expropriation 
score of 7.33 for human capital investment and 4.90 for physical capital investment. ${ }^{59}$ In countries with a high risk of expropriation (a score below 4.90) the social returns to both types of capital investment are negative. Increases in either type of capital have a positive effect on output per worker in countries with a risk of expropriation score greater than 7.33 .

\section{Figure 4.4}

\section{The Marginal Effect of Capital on Growth: An Estimate}

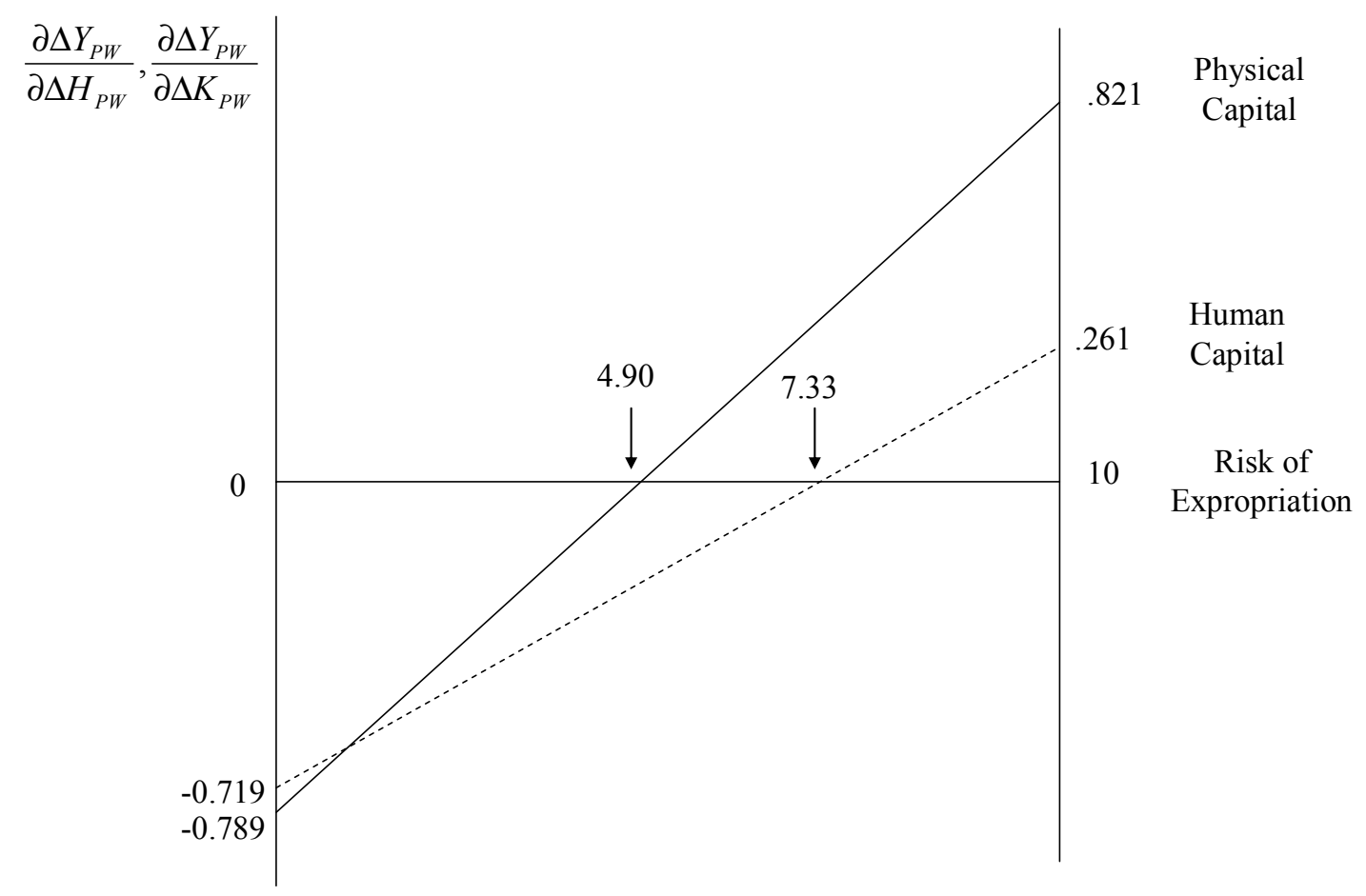

The level of institutional quality required to generate a positive return to education is higher than the level necessary to produce a positive return to physical capital investment. This implies that in countries with mid-range scores (between 4.90

${ }^{59}$ A risk of expropriation score of 7.33 is a consistent with the institutions of a country such as South Africa while Guinea-Bissau is a country just below 4.90. 
and 7.33) that focusing on investments in physical capital are likely to promote economic development to a much greater extent than additional investments in human capital. The greater slope coefficient for physical capital implies that the productivity of physical capital investment is more sensitive to institutional quality than the productivity of human capital investment.

My estimates explain why some countries that have had large increases in formal schooling from 1980 to 2000 have also seen real output decline over that period. A country that falls in this category is Haiti, which had an average risk of expropriation over this period of 4.17. Education levels in Haiti increased by over 120 percent from 1980 to 2000 . At the same time, however, real output per worker declined by 26 percent. Guineau-Bissau, Iran, Madagascar, Niger, the Republic of the Congo, and Uganda are all countries with low (below 5.6) risk of expropriation scores that had increases in education levels over 80 percent and real output per worker declines of greater than 20 percent.

\subsection{Sensitivity Analysis}

A potential concern about the basic results presented in Section 6 is that they might be sensitive to how institutional quality or changes in schooling are measured. For example, much of the cross-country economic growth literature uses educational levels from Barro and Lee (2000). While I employ the Baier, Dwyer and Tamura (2006) data in our initial analysis because I believe they are more up-to-date and expansive than the Barro-Lee calculations, I obtained the Barro-Lee data for the available countries in our data set in order to test the robustness of our results to an alternative measure of schooling increase. 
From the Barro and Lee (2000) data set I obtained the years of education for individuals fifteen and older in 1980 and 2000 and then calculated the change in education from 1980 to $2000 .^{60}$ Twelve countries in our sample were not in the data set thus the sample contains only 84 countries. ${ }^{61}$ The correlation between the two measures of schooling is 0.56 .

Table 4.2 presents the results using the Barro and Lee measure of schooling rather than the Baier, Dwyer and Tamura measure. In the table I consider each of the specifications from Table 1. The basic specification is in Column 1, and the results are similar in significance to our previous results. In the other specifications the results are consistent with those in Table 1 with the exception of the growth of physical capital per worker. While the sign on that variable is still negative, it is not statistically significant in Columns 2-4. Two other items of note are that air distance from major trading centers is statistically significant and the coefficient on the percentage of population within 100k of the coast now has the correct sign.

To this point our measure of institutional quality has been the 'risk of expropriation' of private property. The other measure of institutions frequently employed in the literature is the Economic Freedom of the World (EFW) index by Gwartney and Lawson (2003). The EFW index measures the degree to which a country's economy is consistent with 'economic freedom,' e.g., personal choice, voluntary exchange, and security of private property.

\footnotetext{
${ }^{60}$ Note that here education is not measured in per worker terms but in per capita (15 and older) terms. The Barro and Lee (2000) data set does not provide enough detail for conversion to per worker terms.

${ }^{61}$ The regressions presented in Table 1 were run using only the 84 countries available in Table 2 and the results were qualitatively and quantitatively similar.
} 
Table 4.2

The Determinants of Economic Growth: Alternative Measure of Education

\begin{tabular}{|c|c|c|c|c|}
\hline \multicolumn{5}{|c|}{ Dependent Variable: Growth of Output per Worker, 1980-2000 } \\
\hline Independent Variables & 1 & 2 & 3 & 4 \\
\hline \multirow[t]{2}{*}{ Constant } & 2.20 & 1.21 & 10.74 & $12.74 * * *$ \\
\hline & $(0.39)$ & $(0.17)$ & $(1.53)$ & $(2.67)$ \\
\hline Growth of Schooling Per Worker & $-0.800 * * *$ & $-0.788 * * *$ & $-0.779 * * *$ & $-0.628 * *$ \\
\hline (Barro), 1980-2000 & $(3.10)$ & $(2.92)$ & $(2.81)$ & $(2.37)$ \\
\hline Growth of Physical Capital Per & $-0.593 *$ & $-0.592 *$ & -0.478 & -0.470 \\
\hline Worker, 1980-2000 & $(1.85)$ & $(1.83)$ & $(1.50)$ & $(1.43)$ \\
\hline Growth of Schooling Per Worker $\times$ & $0.106^{* * *}$ & $0.104 * *$ & $0.106 * *$ & $0.087^{* *}$ \\
\hline Risk of Expropriation & $(2.69)$ & $(2.52)$ & $(2.54)$ & $(2.28)$ \\
\hline Growth of Physical Capital Per & $0.134 * * *$ & $0.133 * * *$ & $0.117 * * *$ & $0.117 * * *$ \\
\hline Worker $\times$ Risk of Expropriation & $(3.47)$ & $(3.43)$ & $(3.05)$ & $(2.98)$ \\
\hline Percentage of Population within & & 0.017 & & \\
\hline $100 \mathrm{~km}$ of Coast & & $(0.18)$ & & \\
\hline Air Distance from Major Trading & & & $-0.0023 *$ & \\
\hline Centers & & & $(1.69)$ & \\
\hline Percentage of Land Area Located & & & & $-0.243 * * *$ \\
\hline in Tropics & & & & $(3.21)$ \\
\hline Number of Observations & 84 & 84 & 84 & 84 \\
\hline Adj. r-squared & 0.67 & 0.63 & 0.64 & 0.68 \\
\hline
\end{tabular}

Absolute value of heteroskedasticity-corrected t-statistics in parentheses.

* indicates significance at the $10 \%$ level, $* *$ at $5 \%$ level and *** at the $1 \%$ level.

The index measures the quality of a country's policies and institutions in five areas: (1) size of government, (2) legal structure and security of property rights, (3) access to sound money, (4) freedom to trade internationally, and (5) regulation of capital, labor, and business. Data from third-party international sources such as the World Bank and IMF are used to derive each country's ratings in each the five areas. The area rankings are then averaged together to create a summary ranking for each country 
included in the index. ${ }^{62}$ The ranking theoretically varies from 0 (no economic freedom) to 10 (complete economic freedom).

As an additional measure of institutions, the EFW index has two advantages. First, like the risk of expropriation data, the index has been used in a number of studies on institutions and growth (see, for example, Dawson 1998; Sturm and De Haan 2001; Adkins, Moomaw, and Savvides, 2002; Cole 2003; Gwartney, Holcombe, and Lawson 2006). Second, since the EFW index is calculated using policy variables such as tax rates, use of the index provides clearer guidance to policymakers unlike indirect measures of institutions such as surveys or instrumental variables (Gwartney, Holcombe, and Lawson 2006). For the time period of 1980 to 2000, the EFW index is available at fiveyear intervals starting with 1980 . The average country in the data set had a mean economic freedom score of 5.67, equal to Guatemala's mean summary ranking for the period. Hong Kong has the highest average economic freedom over the period with a score of 8.6 and the Democratic Republic of the Congo has the lowest score at 3.61.

Table 4.3 shows the results for the regressions run in Table 4.1 with the average EFW score inserted used instead of the risk of expropriation. The results are less robust using the EFW index, with growth of physical capital per worker and its interaction with the index being statistically insignificant in all but the last specification. The growth of schooling per worker and its interaction with economic freedom have the correct signs, however, and are strongly significant except in the final specification that includes the tropical location variable. In all cases, however, a joint $F$-test shows that each pair of

\footnotetext{
${ }^{62}$ The most recent version of the EFW index (Gwartney and Lawson, 2006), which measures economic freedom for 2004, rates 130 countries. The decision to include or exclude from the index depends solely on the quality of the available data, with data being unavailable mainly for autocratic or small countries.
} 
variables is jointly significant. These results seem to confirm the general hypothesized relationship found earlier.

Table 4.3

The Determinants of Economic Growth: Alternative Meas ure of Institutions

\begin{tabular}{lcccc}
\hline \multicolumn{4}{c}{ Dependent Variable: Growth of Output per Worker, $1980-2000$} & \\
\hline \multicolumn{1}{c}{ Independent Variables } & 1 & 2 & 3 & 4 \\
\hline Constant & $9.27 *$ & 12.96 & $26.05 * * *$ & $24.49 * * *$ \\
& $(1.68)$ & $(1.21)$ & $(2.94)$ & $(3.44)$ \\
Growth of Schooling Per Worker & $-0.732 * * *$ & $-0.782 * * *$ & $-0.529 * *$ & -0.297 \\
(Baier et al.), 1980-2000 & $(3.03)$ & $(2.78)$ & $(2.18)$ & $(0.96)$ \\
Growth of Physical Capital Per & -0.220 & -0.234 & -0.192 & -0.431 \\
Worker, 1980-2000 & $(0.50)$ & $(0.53)$ & $(0.50)$ & $(1.25)$ \\
Growth of Schooling Per Worker $\times$ & $0.109 * * *$ & $0.116 * * *$ & $0.079 * *$ & 0.044 \\
Avg EFW 1980-2000 & $(3.03)$ & $(2.78)$ & $(2.19)$ & $(0.97)$ \\
Growth of Physical Capital Per & 0.097 & 0.100 & 0.091 & $0.129 * *$ \\
Worker $\times$ Avg EFW 1980-2000 & $(1.46)$ & $(1.52)$ & $(1.55)$ & $(2.47)$ \\
Percentage of Population within & & -0.06 & & \\
100km of Coast & & $(0.47)$ & & \\
Air Distance from Major Trading & & & $-0.005 * *$ & $(2.48)$ \\
Centers & & & & $-0.376 * * *$ \\
Percentage of Land Area Located & & & & $(3.70)$ \\
in Tropics & & 103 & 103 & 0.44 \\
\hline Number of Observations & 0.35 & 0.35 & 0.39 & \\
Adj. r-squared & & & & \\
\hline Absolyte value of he & & & \\
\hline
\end{tabular}

Absolute value of heteroskedasticity-corrected t-statistics in parentheses.

* indicates significance at the $10 \%$ level, ** at $5 \%$ level and *** at the $1 \%$ level.

\subsection{Conclusion}

Since World War II, the development-policymaking community has stressed the importance of capital accumulation. Large amounts of aid from developed countries and international aid organizations such as the International Monetary Fund and World Bank 
have flowed to developing countries to encourage the capital investment though necessary for poor countries to 'take-off' on the path to development. Cross-country studies show, however, that the macroeconomic relationship between capital accumulation and growth is not as robust as the microeconomic relationship would suggest.

In this paper I provide an answer to this paradox by developing a model that allows the effect of changes in capital on changes in output per worker to vary along with the quality of institutions in a country. I empirically test this hypothesis using data on a large cross-section of countries and find that the effect of changes in human and physical capital varies considerably along the institutional quality continuum, measured by IRG data on the risk of expropriation within a country. I calculate that for countries with risk of expropriation scores below 4.90, additions to both the stock of physical and human capital have a negative effect on growth of output per worker. For countries between 4.90 and 7.33, increases in physical capital per worker have a positive impact but increases in schooling are still negative. Above 7.33, all increases in capital per worker increase output per worker.

The finding that capital increases only have a positive impact on growth once a 'break-even' level of institutional quality is a strong argument against naive proposals to double the capital stock in developing countries to double their income. ${ }^{63}$ If aid flows are inevitable, however, these findings suggest that spending should be focused on investment in physical capital if the country has a risk of expropriation score between 4.90 and 7.33. More importantly, however, these results focus attention towards

${ }^{63}$ For example, Jeffrey Sachs $(2005,250)$ has said that "The likelihood is that doubling the human and physical capital stock will actually more than double the income level, at least at very low levels of capital per person." 
institutional reform as the key to economic progress so that future increases in physical and human capital will generate positive social returns as well as private ones. 


\section{Chapter 5 \\ Summary and Conclusion}

At its core, the economics of education is about political economy since all of the important questions revolve around government involvement in education financing and provision. Most of the enduring research questions in the economics of education would be of little concern if there were no public involvement in the financing or production of education. The effectiveness of resource usage within schools is a far less interesting and important research question if school spending is the result of voluntary actions between parents and education providers instead of the outcome of collective action. Thus the economic study of education is ultimately about the effectiveness of the political, social, legal, and economic institutions that have evolved over time to finance and produce educated citizens. This dissertation contributes to the scholarly literature by more explicitly considering the effect that the variation in educational institutions across geographic space has on education outcomes and financing.

Chapter 2 analyzes the effect of racial diversity on educational outcomes using cross-sectional data on Ohio school districts. Racial diversity has a negative association with school district passage rates on state proficiency exams. The results are robust to a variety of empirical approaches and alternative specifications and evidence is presented that suggest reverse-causality is not driving the results. The higher a school districts academic performance in 1990 , the more diverse that district was in 2000, suggesting that school quality leads to diversity, not vice versa. While the exact causal link between racial diversity and school performance is unclear, identification of a negative relationship between diversity at the school district level and school district performance 
is a first step towards determining if the cause is the racial peer effect channel or the voting channel.

A one standard deviation increase in racial diversity is associated with a decline in district math test scores of between 1.1 and 3.3 percentage points, depending upon the empirical specification. While seemingly not that large, recall that this is the net effect of racial diversity on test scores. Since some previous research has found that AfricanAmerican students benefit from increased diversity while White and Asian students do worse from it, this suggests that the effects of diversity on individuals might be quite larger if disaggregated. At the same time, however, maximizing school performance is not the same thing as maximizing utility. Households take many factors into account before deciding where to live and send their children to school (Pritchett and Filmer 1999). The possibility of lower test scores might well be an acceptable trade-off for parents wanting to live in a racially diverse community.

Over the past thirty years a primary reason for the increase in state financing of education has been a wave of court-ordered school finance reforms that have significantly increased state spending on education (Murray, Evans, and Schwab 1998). There have been efforts in nearly every state to challenge the constitutionality of school finance systems that produce unequal levels of school funding and unequal school outcomes among school districts. Even in states where the school funding system was ruled to be constitutional, litigation has spurred considerable changes. Since 1970, every state has changed their school finance system to create a more equal distribution of funding among districts (Hoxby 2001). States responded in many ways to these constitutional challenges. 
Ohio, for example, gave school districts the ability to raise additional revenue by levying a tax on income instead of relying solely on property taxes.

The fact that the State of Ohio gave local school districts the option of asking voters to approve a school district income tax provides an excellent opportunity to test some elements of the literature on government choice among tax instruments. Standard public finance principles would suggest that local governments such as school districts should diversify across as many revenues sources as possible. The idea is that diversification helps to mitigate the effects of any adverse shocks to school district revenues. A school district relying too much on the property tax, for example, might see a catastrophic fall in revenues if the largest manufacturer in the area closed. Given this risk, it is surprising that only one-fifth of school districts in Ohio utilize the income tax.

Spry (2005) provides evidence that competition among local school districts depresses the use of an income tax. The argument is that a school district enacting an income tax in an area with a competitive local education market would soon see all of its high-income households migrate to nearby districts without an income tax. Only in rural areas where the costs of moving are higher either in terms of commuting distance (if remaining at current job) or job relocation will we see widespread use of an income tax, other things equal. This explanation fits the raw data very well, since most of the school districts using the income tax are in rural areas.

Chapter 3 uses spatial econometric techniques to test for spatial dependence and spatial error correlation in the use of an income tax. Once spatial effects are accounted for, fiscal competition among local school districts no longer is found to depress use of the income tax. The spatial lag term is positive and significant, providing evidence of 
yardstick competition in income tax adoption. School districts are more likely to adopt an income tax if their neighbors currently utilize and income tax. The empirical results point to tax exporting as the primary reason why school districts do not utilize the income tax more often. The burden of the school district income tax is 100 percent on local residents, whereas some proportion of a property tax that raised the same amount of revenue would be exported onto non-resident property owners. Given that, the more interesting question is not why do so few school districts utilize the income tax but why do so many?

While Chapters 2 and 3 deal with fairly narrow but important topics in the economics of education, Chapter 4 deals with the link between education and growth. Chapter 4 focuses on the importance of institutions for the return on the accumulation of human and physical capital. Since the 1940s, the international development community has advocated and funded human and physical capital accumulation efforts in the developing world to push these countries onto a higher growth path. The cross-country evidence is mixed, however, and sometimes countries economically stagnate in spite of significant increases in education levels and physical capital.

Chapter 4 develops a theoretical model that allows the effect of changes in capital on output growth per worker to vary with institutional quality. Using a large cross-section of countries, I empirically test this model using data on the 'risk of expropriation' within a country as a measure of institutional quality. The results of the chapter are that the return on human and physical capital investment does vary considerably with institutional quality. For countries with risk of expropriation scores up to 4.90 , additions to human and physical capital lower the growth of output per worker. Between 4.90 and 7.33, physical capital per worker has a positive impact on growth of output per worker but increasing 
human capital per worker still reduces growth of output per worker. When the risk of expropriation in a country is above 7.33 , increases in both human and physical capital per worker raise the growth rate of output per worker.

This finding has three important implications for international development efforts. First, it shows that lack of capital is not the primary problem facing most undeveloped nations. Second, assuming holding the amount of foreign aid going to a country constant, the returns to physical and human capital differ at different levels of institutional quality. Specifically, for those countries with risk of expropriation scores between 4.90 and 7.33, aid should be shifted towards physical capital accumulation and away from human capital accumulation efforts. More importantly, the third implication of Chapter 4 is that development efforts should be focused on reforming institutions. 


\section{References}

Acemoglu, Daron and Simon Johnson. 2005. "Unbundling Institutions." Journal of Political Economy vol. 113, no. 5 (October): 949-995.

Acemoglu, Daron, Simon Johnson, and James A. Robinson. 2001a. "Reversal of Fortune: Geography and Institutions in the Making of the Modern World Income Distribution." Quarterly Journal of Economics vol. 117, no. 4 (November): 12311294.

Acemoglu, Daron, Simon Johnson, and James A. Robinson. 2001b. "The Colonial Origins of Comparative Development: An Empirical Investigation." American Economic Review vol. 91, no. 5 (December): 1369-1401.

Adkins, Lee C., Ronald L. Moomaw, and Andreas Savvides. 2002. "Institutions, Freedom, and Technical Efficiency." Southern Economic Journal vol. 69, no. 4 (July): 92-108.

Alesina, Alberto, Reza Baqir, and William Easterly. 1999. "Public Goods and Ethnic Divisions." Quarterly Journal of Economics vol. 114, no. 4 (November): 12431284.

Alesina, Alberto, Arnaud Devleeschauwer, William Easterly, Sergio Kurlat, and Romain Wacziarg. 2003. "Fractionalization." Journal of Economic Growth vol. 8, no 2 (June): 155-194.

Angrist, Joshua D., and Kevin Lang. 2004. "Does School Integration Generate Peer Effects? Evidence from Boston's Metco Program." American Economic Review vol. 94, no. 5 (December): 1613-1634.

Anselin, Luc. 1988. Spatial Econometrics: Methods and Models. Dordrecht: Kluwer Academic Publishers.

Anselin, Luc. 2002. "Under the Hood: Issues in the Specification and Interpretation of Spatial Regression Models." Agricultural Economics vol. 27, no 3 (November): 247-267.

Arndt, H.W. 1997. Economic Development: The History of an Idea. Chicago: University of Chicago Press.

Armor, David J. 1995. Forced Justice: School Desegregation and the Law. New York, NY: Oxford University Press. 
Baier, Scott L., Gerald P. Dwyer, and Robert Tamura. 2006. "How Important are Capital and Total Factor Productivity for Economic Growth." Economic Inquiry vol. 44, no. 1 (January): 23-49.

Barro, Robert J. 1991. "Economic Growth in a Cross-Section of Countries." Quarterly Journal of Economics vol. 106, no. 2 (May): 407-433.

Barro, Robert J. and Xavier Sala-i-Martin. 1995. Economic Growth. New York: McGraw-Hill.

Barro, Robert J., and Jong-Wha Lee. 2000. "International Data on Educational Attainment: Updates and Implications.” CID Working Paper No. 42.

Bauer, Peter T. 1948. The Rubber Industry: A Study in Competition and Monopoly. London: Longmans, Green \& Company.

Bauer, Peter T. 1954. West African Trade: A Study of Competition, Oligopoly and Monopoly in a Changing Economy. Cambridge: Cambridge University Press.

Bauer, Peter T. 1957. Economic Analysis and Policy in Underdeveloped Countries. Durham, NC: Duke University Press.

Baumol, William J. 1990. "Entrepreneurship: Productive, Unproductive and Destructive." Journal of Political Economy vol. 98, no. 5 (October): 893-921.

Becker, Gary S. 1964 [1975]. Human Capital. New York, NY: National Bureau of Economic Research.

Bénabou, Roland. 1996. "Heterogeneity, Stratification, and Growth: Macroeconomic Implications of Community Structure and School Finance." American Economic Review vol. 86, no. 3 (June): 584-609.

Berkman, Michael B., and Eric Plutzer. 2004. "Grey Peril or Loyal Support? The Effects of the Elderly on Educational Expenditures." Social Science Quarterly vol. 85, no. 5 (December): 1178-1192.

Bernstein, Elizabeth. 2 April 2004. "The Price of Admission." Wall Street Journal, page W1.

Beron, Kurt J., and Wim P.M. Vijverberg. 2004. "Probit in a Spatial Context: A Monte Carlo Analysis." In Luc Anselin, Raymond J.G.M. Florax, and Sergio J. Rey, eds., Advances in Spatial Econometrics, 169-195. Berlin: Springer Verlag.

Belsley, David A., Edwin Kuh, and Roy E. Welsch. 1980. Regression Diagnostics: Identifying Influential Data and Sources of Collinearity. New York: Wiley. 
Besley, Timothy, and Anne C. Case. 1995. "Incumbent Behavior: Vote Seeking, Tax Setting and Yardstick Competition." American Economic Review vol. 85, no. 1 (March): 25-45.

Bier, Thomas. 2001. Moving Up, Filtering Down: Metropolitan Housing Dynamics and Public Policy. Washington, DC: Brookings Institution.

Blaug, Mark. 1972. "Review of Investment in Human Capital: The Role of Education and of Research by Theodore W. Schultz." Journal of Business vol. 45, no. 1 (January): 113.

Blaug, Mark. 1976. "The Empirical Status of Human Capital Theory: A Slightly Jaundiced Survey." Journal of Economic Literature vol. 14, no. 3 (September): 827-855.

Boettke, Peter. 2001. Calculation and Coordination: Essays on Socialism and Transitional Political Economy. London: Routledge.

Boettke, Peter J., and Peter T. Leeson. 2007. "Two-Tiered Entrepreneurship and Economic Development." Mimeo.

Borland, Melvin V., and Roy M. Howsen. 1996. "Competition, Expenditures and Student Performance in Mathematics: A Comment on Couch et al." Public Choice vol. 87, nos. 3-4 (June): 395-400.

Brand-Williams, Oralandar. 28 January 2002. "Shaker Heights: City Works at Integration." Detroit News.

Brasington, David M. 1999. "Which Measures of School Quality Does the Housing Market Value?" Spatial and Non-Spatial Evidence." Journal of Real Estate Research vol. 18, no. 3 (November-December): 395-413.

Brasington, David M. 2007. "Public and Private School Competition: The Spatial Education Production Function.” In I T. Asada and T. Ishikawa (eds.) Time and Space in Economics. Tokyo: Springer: 175-203.

Brasington, David M., and Diane Hite. 2005. "Demand for Environmental Quality: A Spatial Hedonic Analysis." Regional Science and Urban Economics vol. 35, no. 1 (January): 57-82

Brennan, Geoffrey, and James M. Buchanan. 1980. The Power to Tax: Analytical Foundations of a Fiscal Constitution. Cambridge: Cambridge University Press.

Brueckner, Jan, and Luz A. Saavedra. 2001. "Do Local Governments Engage in Strategic Property-Tax Competition?” National Tax Journal vol. 54, no. 2 (June): 203-229. 
Brunner, Eric, and Ed Balsdon. 2004. "Intergenerational Conflict and the Political Economy of School Spending." Journal of Urban Economics vol. 56, no. 2 (September): 369-388.

Busch, Ronald J., Douglas O. Stewart, and Allan J. Taub. 1999. "Ohio's City-School District Income Tax: A Tale of Two Cities." Journal of Education Finance vol. 24, no. 3 (Winter): 339-352.

Button, James W. 1992. "A Sign of Generational Conflict: The Impact of Florida's Aging Voters on Local School and Tax Referenda." Social Science Quarterly vol. 73, no. 4 (December): 786-797.

Caplan, Bryan. 2001. "Standing Tiebout on His Head: Tax Capitalization and the Monopoly Power of Local Governments." Public Choice vol. 108, no. 1/2 (July): $101-122$.

Clotfelter, Charles T. 1976. "School Desegregation, 'Tipping,' and Private School Enrollment." Journal of Human Resources vol. 11, no. 1 (Winter): 28-50.

Clotfelter, Charles T. 1999. "Public School Segregation in Metropolitan Areas." Land Economics vol. 75, no. 4 (November): 487-504.

Coleman, James S., Ernest Q. Campbell, Carol J. Hobson, James McPartland, Alexander M. Mood, Frederic D. Weinfeld, and Robert L. York. 1966. Equality of Educational Opportunity. Washington, DC: Government Printing Office.

Cole, Julio H. 2003. "The Contribution of Economic Freedom to World Economic Growth: 1980-99." Cato Journal vol. 23, no. 2 (Fall): 189-198.

Coyne, Christopher J., and Peter J. Boettke. 2006. "The Role of the Economist in Economic Development." The Quarterly Journal of Austrian Economics vol. 19, no. 2 (Summer): 47-68.

De Long, J. Bradford. 1988. "Productivity Growth, Convergence, and Welfare: Comment." American Economic Review vol. 78, no. 5 (December): 1138-1154.

Driscoll, Donna, Dennis Halcoussis and Shirley Svorny. 2003. "School District Size and Student Performance." Economics of Education Review vol. 22, no. 2 (April): 193-201.

Easterly, William, and Ross Levine. 1997. "Africa's Growth Tragedy: Policies and Ethnic Divisions." Quarterly Journal of Economics vol. 62, no. 4 (November): 1203-1250.

Easterly, William. 2001. The Elusive Quest for Growth. Cambridge, MA: MIT Press. 
Easterly, William. 2006a. "Planners vs. Searchers in Foreign Aid." Asian Development Review vol. 23, no. 2: 1-35.

Easterly, William. 2006b. "Reliving the 50s: the Big Push, Poverty Traps, and Takeoffs in Economic Development." Journal of Economic Growth vol. 11, no. 4 (December): 289-318.

Echenique, Federico, Roland G. Fryer, and Alex Kaufman. 2006. "Is School Segregation Good or Bad? American Economic Review vol. 96, no. 2 (May): 265-269.

Fairlie, Robert W., and Alexandra M. Resch. 2002. "Is There 'White Flight' Into Private Schools? Evidence from the National Educational Longitudinal Survey." The Review of Economics and Statistics vol. 84, no. 1 (February): 21-33.

Fischel, William A. 2001. "Homevoters, Municipal Corporate Governance, and the Benefit View of the Property Tax." National Tax Journal vol. 54, no. 1 (March): 157-174.

Fischel, William A. 2007. "The Congruence of American School Districts with Other Local Government Characteristics: A Google-Earth Explanation.” Dartmouth College Economics Department Working Paper.

Fisher, Mark. 8 June 2001. "Math Still Proficiency Stumbling Block: Subject Stopped 107 County Seniors from Graduating." Dayton Daily News.

Fiva, Jon H., and Jørn Rattsø. 2007. "Local Choice of Property Taxation: Evidence from Norway." Public Choice, forthcoming.

Fleming, Mark. 2004. "Techniques for Estimating Spatially Dependent Discrete Choice Models." In L. Anselin, R. J. G. M. Florax, and S. J. Rey (Eds). Advances in Spatial Econometrics: Methodology, Tools and Applications. Berlin: SpringerVerlag.

Fox, William F. 1981. "Reviewing Economies of Size in Education." Journal of Education Finance vol. 6, no. 3 (Winter): 273-96.

Friedman, Milton, and Rose Friedman. 1980. Free to Chose: A Personal Statement. New York, NY: Harcourt, Brace and Jovanovich.

Gallup, John L., Jeffrey D. Sachs, and Andrew Mellinger. 1999. "Geography and Economic Development." CID Working Paper No. 1. Cambridge, MA: Center for International Development.

Goldhaber, Dan D., and Dominic J. Brewer. 1997. "Why Don't Schools and Teachers Seem to Matter? Assessing the Impact of Unobservables on Educational Productivity." Journal of Human Resources vol. 32, no. 3 (Summer): 505-521. 
Goodspeed, Timothy J. 1998. "Tax Competition, Benefit Taxes, and Fiscal Federalism." National Tax Journal 51, no. 3: 579-586.

Greene, Jay P. 1999. Community and Choice: The Racial, Economic, and Religious Context of Parental Choice in Cleveland. Columbus, OH: The Buckeye Institute.

Griliches, Zvi. 1997. "Education, Human Capital and Growth: A Personal Perspective." Journal of Labor Economics vol. 15, no. 1 part 2. (January): S330-S344.

Guryan, Jonathan. 2004. "Desegregation and Black Dropout Rates." American Economic Review vol. 94, no. 4 (September): 919-943.

Gwartney, James D., and Robert A. Lawson. 2003. Economic Freedom of the World: 2003 Annual Report. Vancouver: Frasier Institute.

Gwartney, James D., and Robert A. Lawson. 2006. Economic Freedom of the World: 2006 Annual Report. Vancouver: Frasier Institute.

Gwartney, James D., Randall G. Holcombe, and Robert A. Lawson. 2004. "Economic Freedom, Institutional Quality, and Cross-Country Differences in Income and Growth." Cato Journal vol. 24, no. 3 (Fall): 205-233.

Gwartney, James D., Randall G. Holcombe, and Robert A. Lawson. 2006. "Institutions and the Impact of Investment on Growth.” Kyklos vol. 59, no. 2 (May): 255-273.

Hall, Joshua C. 2000. Investment in Education: Public and Private Returns. Washington, DC: Joint Economic Committee.

Hall, Joshua C. 2006. "Fiscal Competition and Tax Instrument Choice: The Role of Income Inequality," Economics Bulletin vol. 8, no. 12: 1-8.

Hanushek, Eric. A. 1996. "Measuring Investment in Education." Journal of Economic Perspectives vol. 10, no. 4 (Autumn): 9-30.

Hanushek, Eric A. 1997. "Assessing the Effects of School Resources on Student Performance: An Update." Education Evaluation and Policy Analysis vol. 19, no. 2 (Summer): 1414-164.

Hanushek, Eric A. 2002. "Publicly Provided Education." In Alan J. Auerbach and Martin Feldstein, eds., Handbook of Public Economics. Amsterdam: North-Holland: 2045-2141.

Hanushek, Eric A., John F. Kain, and Steven G. Rivkin. 2004. "New Evidence about Brown v. Board of Education: The Complex Effects of School Racial 
Composition on Achievement." Cambridge: National Bureau of Economic Research Working Paper No. 8741, October (updated).

Hedges, Larry V., and Rob Greenwald. 1996. "Have Times Changed? The Relationship between School Resources and Student Performance.” In Gary Burtless, ed., Does Money Matter? The Effect of School Resources on Student Achievement and Adult Success. Washington, DC: Brookings Institution Press.

Heinesen, Eskil. 2005. "School District Size and Student Educational Attainment: Evidence from Denmark." Economics of Education Review vol. 24, no. 6 (December): 677-89.

Hoxby, Caroline M. 2000a. "Does Competition Among Public Schools Benefit Students and Taxpayers?” American Economic Review vol. 90, no. 5:1209-1238.

Hoxby, Caroline M. 2000b. "Peer Effects in the Classroom: Learning from Gender and Race Variation." Cambridge: National Bureau of Economic Research Working Paper No. 7867, August.

Hoxby, Caroline M. 2001. "All School Finance Equalizations Are Not Created Equal." Quarterly Journal of Economics vol. 116, no. 4 (November): 1189-1231.

Jencks, Christopher, Marshall Smith, Henry Acland, Mary Jo Bane, David Cohen, Herbert Gintis, Barbara Heyns and Stephan Michelson. 1972. Inequality: A Reassessment of the Effects of Family and Schooling in America. New York, NY: Basic Books.

Jud, G. Donald, and D. Gordon Bennett. 1986. "Public Schools and the Pattern of Intraurban Residential Mobility." Land Economics vol. 62, no. 4 (November): 362-370.

Kenny, Lawrence B., and Amy B. Schmidt. 1994. "The Decline in the Number of School Districts in the U.S.: 1950-1980." Public Choice vol. 79, no. 1: 1-18.

Krueger, Alan B. 2003. "Economic Considerations and Class Size." Economic Journal vol. 113, no. 485 (February): F34-F63.

Leal, David L., and Frederick M. Hess. 2000. "The Politics of Bilingual Education Expenditures in Urban School Districts." Social Science Quarterly vol. 81, no. 4 (December): 1064-72.

LeSage, James. P. 1997. "Regression Analysis of Spatial Data." Journal of Regional Analysis and Policy vol. 27, no. 2: 83-94.

LeSage, James P. 1999. "Spatial Econometrics." In The Web Book of Regional Science (www.rri.wvu.edu/regscweb.htm), ed., Scott Loveridge. Morgantown, WV: Regional Research Institute, West Virginia University. 
Lewis, Sir Arthur. 1992. “Autobiography.” In Nobel Lectures, Economics Sciences 19691980. Assar Lindbeck (ed). Singapore: World Scientific Publishing Co.

Mankiw, N. Gregory, David Romer, and David N. Weil. 1992. "A Contribution to the Empirics of Economic Growth.” Quarterly Journal of Economics vol. 107, no. 2 (May): 407-437.

Mieszkowski, P., and G. Zodrow. 1989. "Taxation and the Tiebout Model: The Differential Effects of Head Taxes, Taxes on Land Rents, and Property Taxes." Journal of Economic Literature vol. 27, no. 3 (September): 1098-1146.

Mur, Jesus, and Ana Angulo. 2005. "A Closer Look at the Spatial Durbin Model." Mimeo.

Murphy, Kevin M., Andrei Shleifer, and Robert W. Vishny. 1991. "The Allocation of Talent: Implications for Growth.” Quarterly Journal of Economics vol. 106, no. 2 (May): 503-530.

Murray, Sheila E., William N. Evans and Robert W. Schwab. 1998. "Education Finance Reform and the Distribution of Education Resources." American Economic Review vol. 88, no. 4 (September): 789-812.

National Center for Education Statistics. 1994. School District Data Book. Washington, DC: National Center for Education Statistics.

Niskanen, William A. 1998. "Student Performance and School District Size." In William A. Niskanen (ed.), Policy Analysis and Public Choice: Selected Papers by William Niskanen. Cheltenham, UK: Edward Elgar, 124-134.

Norstrand, Rolf. 1980. "The Choice between Income Tax and Land Tax in Danish Municipalities. Public Finance vol. 35, no. 3: 412-24.

North, Douglass C. 1991. "Institutions." Journal of Economic Perspectives vol. 5, no. 1 (Winter): 97-112.

Oates, Wallace E. 1999. "An Essay on Fiscal Federalism." Journal of Economic Literature vol. 37, no. 3 (September): 1120-1149.

Ohio Department of Education. 2005. Cupp Report [electronic file]. Columbus, OH: Ohio Department of Education.

Ohio Department of Education. 2007. District Profile Report (formerly Cupp Report) [electronic file]. Columbus, $\mathrm{OH}$ : Ohio Department of Education. 
Ohio Department of Taxation. 2007. Tax Data Series: School District Data [electronic file]. Columbus, OH: Ohio Department of Taxation.

Pace, R. Kelley, and James P. LeSage. 2007. "Biases of OLS and Spatial Lag Models in the Presence of an Omitted Variable and Spatially Dependent Variables." Mimeo.

Pace, R. Kelley., Ronald Barry, and C. F. Sirmans. 1998. "Spatial Statistics and Real Estate." Journal of Real Estate Finance and Economics vol. 17, no. 1 (July): 5-13.

Palmon, Oded, and Barton A. Smith. 1998. "New Evidence on Property Tax Capitalization." Journal of Political Economy vol.106, no. 5 (October): 10991111.

Powell, Benjamin. 2004. "Competition and Monopoly Power in Local Government: An Extension of Caplan." Public Choice vol. 120, no. 3/4 (September): 353-357.

Poterba, James M. 1997. "Demographic Structure and the Political Economy of Public Education." Journal of Policy Analysis and Management vol. 16, no. 1 (Winter): 48-66.

Pritchett, Lant, and Deon Filmer. 1999. "What Education Production Functions Really Show: A Positive Theory of Education Expenditures." Economics of Education Review vol. 18, no. 2 (April): 223-239.

Pritchett, Lant. 2001. "Where Has All The Education Gone?" The World Bank Economic Review vol. 15, no. 3: 367-91.

PRS Group. 2007. International Country Risk Guide [electronic file]. East Syracuse, NY: PRS Group.

Psacharopoulos, George. 1985. "Returns to Education: A Further International Update and Implications." Journal of Human Resources vol. 20, no. 4 (Autumn): 583604.

Renzulli, Linda A., and Lorraine Evans. 2005. "School Choice, Charter Schools, and White Flight." Social Problems vol. 52, no. 3: 398-418.

Rincke, Johannes. 2006. "Policy Innovation in Local Jurisdictions: Testing for Neighborhood Influence in School Choice Policies." Public Choice vol. 129, nos. 1-2 (October): 189-200.

Rivkin, Steven G., Eric A. Hanushek, and John F. Kain. 2005. "Teachers, Schools, and Academic Achievement." Econometrica vol. 73, no. 2 (March); 417-458. 
Rodrik, Dani, Arvind Subramanian, and Francesco Trebbi. 2004. "Institutions Rule: The Primacy of Institutions over Geography and Integration in Economic Development." Journal of Economic Growth vol. 9, no. 2 (June): 135-165.

Romer, Paul. 1986. "Increasing Returns and Long Run Growth." Journal of Political Economy vol. 94, no. 5 (October): 1002-1037.

Romer, Thomas, Howard Rosenthal, and Vincent G. Munley. 1992. "Economic Incentives and Political Institutions: Spending and Voting in School Budget Referenda." Journal of Public Economics vol. 49, no. 1 (October): 1-33.

Rosen, Sherwin. 1993. "Risks and Rewards: Gary Becker's Contributions to Economics." Scandinavian Journal of Economics vol. 95, no. 1. (March): 25-36.

Rothstein, Jesse. 2005. "Does Competition Among Public Schools Benefit Students and Taxpayers? A Comment on Hoxby (2000)." Cambridge: National Bureau of Economic Research Working Paper \#11215, March.

Sachs, Jeffrey D. 2003. "Institutions Don't Rule: Direct Effects of Geography on Per Capita Income." NBER Working Paper No. 9490. Cambridge, MA: National Bureau of Economic Research.

Sachs, Jeffrey D. 2005. The End of Poverty: Economic Possibilities for Our Time. New York, NY: The Penguin Press.

Schneider, Mark. 1986. "Fragmentation and the Growth of Local Government." Public Choice vol. 48, no. 3 (January): 255-264.

Schultz, Theodore. 1961. "Investment in Human Capital." American Economic Review vol. 51, no. 1 (March): 1-17.

Shock, David R. 2004-2005. "Voting Behavior in School District Tax Elections: An Analysis of Property and Income Tax Options." Journal of Economics and Politics vol. 17, no. 1: 1-15.

Sjoquist, David. 1981. "A Median Voter Analysis of Variations in the Use of Property Taxes among Local Governments." Public Choice vol. 36, no. 2 (January): 273285.

Smith, Adam. [1776] 1998. An Inquiry into the Nature and Causes of the Wealth of Nations. Washington, D.C.: Regnery.

Solow, Robert M. 1956. "A Contribution to the Theory of Economic Growth." Quarterly Journal of Economics, vol. 70, no. 1: 65-94. 
South, Scott J., and Kyle D. Crowder. 1997. "Residential Mobility between Cities and Suburbs: Race, Suburbanization, and Back-to-the-City Moves." Demography 34, no. 4 (November): 525-538.

Spry, John A. 2005. "The Effects of Fiscal Competition on Local Property and Income Tax Reliance." Topics in Economic Analysis and Policy vol. 5, no. 1: 1-19.

Stansel, Dean A. 2006. "Interjurisdictional Competition and Local Government Spending in U.S. Metropolitan Areas." Public Finance Review vol. 34, no. 2 (March): 173194.

Staley, Samuel R., and John P. Blair. 1995. "Institutions, Quality Competition and Public Service Provision: The Case of Public Education." Constitutional Political Economy vol. 6, no. 1 (Winter): 21-33.

Sturm, Jan Egbert, and Jakob De Haan. 2001. "How Robust is the Relationship between Economic Freedom and Economic Growth?" Applied Economics vol. 33, no. 7 (June): 839-844.

Summers, Robert, and Alan Heston. 2000. Penn World Tables 5.6 [electronic file]. Philadelphia, PA: Center for International Comparisons.

Teixeira, Pedro N. 2000. "A Portrait of the Economics of Education." History of Political Economy vol. 32, suppl. 1: 257-288.

Tiebout, Charles. 1956. "A Pure Theory of Local Expenditures." Journal of Political Economy. 64: 416-24.

U.S. Census Bureau, 2000 Census School District Special Tabulation [electronic file]. Washington, DC: U.S. Census Bureau.

U.S. Commission on Civil Rights. 1967. Racial Isolation in the Public Schools. Washington: Government Printing Office.

Williamson, Oliver E. 1985. The Economic Institutions of Capitalism: Firms, Markets, Relational Contracting. New York: Free Press.

Zax, Jeffrey. 1989. "Is There A Leviathan In Your Neighborhood?" American Economic Review vol. 79, no. 3: 560-567. 


\section{Appendix Table 1}

\section{Racial Diversity and Non-Math Test Scores}

\begin{tabular}{|c|c|c|c|c|}
\hline & Citizenship & Reading & Science & Writing \\
\hline Constant & $\begin{array}{l}-0.94 * * * \\
(3.21)\end{array}$ & $\begin{array}{r}0.16 \\
(0.92)\end{array}$ & $\begin{array}{l}-1.11^{* * *} \\
(3.88)\end{array}$ & $\begin{array}{r}0.23 \\
(1.10)\end{array}$ \\
\hline Racial Diversity 2000 & $\begin{array}{c}-0.1206 * * * \\
(3.51)\end{array}$ & $\begin{array}{c}-0.0951 * * * \\
(3.74)\end{array}$ & $\begin{array}{c}-0.2093 * * * \\
(5.38)\end{array}$ & $\begin{array}{c}-0.0416 * \\
(1.68)\end{array}$ \\
\hline Expenditure Per Pupil & $\begin{array}{r}-0.0045 \\
(1.45)\end{array}$ & $\begin{array}{c}-0.0039 * * \\
(1.97)\end{array}$ & $\begin{array}{c}-0.0074 * * \\
(2.03)\end{array}$ & $\begin{array}{r}-0.0038 \\
(1.48)\end{array}$ \\
\hline Income & $\begin{array}{r}0.0002 \\
(0.30)\end{array}$ & $\begin{array}{r}0.0005 \\
(0.94)\end{array}$ & $\begin{array}{r}0.0005 \\
(0.61)\end{array}$ & $\begin{array}{r}0.0006 \\
(1.03)\end{array}$ \\
\hline Attendance & $\begin{array}{l}1.9351 \text { *** } \\
(6.55)\end{array}$ & $\begin{array}{l}0.8874 * * * \\
(4.96)\end{array}$ & $\begin{array}{l}2.1585 * * * \\
(7.45)\end{array}$ & $\begin{array}{l}0.7801 * * * \\
(3.66)\end{array}$ \\
\hline Pupil/Teacher Ratio & $\begin{array}{r}-0.0014 \\
(0.89)\end{array}$ & $\begin{array}{r}-0.0015 \\
(1.49)\end{array}$ & $\begin{array}{r}-0.0016 \\
(1.04)\end{array}$ & $\begin{array}{c}-0.0026 \text { ** } \\
(2.18)\end{array}$ \\
\hline Average Teacher Salary & $\begin{array}{r}0.0010 \\
(1.15)\end{array}$ & $\begin{array}{r}-0.0001 \\
(0.19)\end{array}$ & $\begin{array}{r}0.0005 \\
(0.47)\end{array}$ & $\begin{array}{r}0.0008 \\
(1.25)\end{array}$ \\
\hline Teacher Inexperience & $\begin{array}{r}-0.0202 \\
(0.56)\end{array}$ & $\begin{array}{r}-0.0212 \\
(0.88)\end{array}$ & $\begin{array}{c}-0.0839 * * \\
(2.35)\end{array}$ & $\begin{array}{r}0.0097 \\
(0.39)\end{array}$ \\
\hline Density & $\begin{array}{c}-0.0027 * \\
(1.95)\end{array}$ & $\begin{array}{r}-0.0017 \\
(1.27)\end{array}$ & $\begin{array}{c}-0.0038 * * \\
(1.99)\end{array}$ & $\begin{array}{c}-0.0018 * \\
(1.84)\end{array}$ \\
\hline District Size & $\begin{array}{c}-0.0012 * * \\
(2.09)\end{array}$ & $\begin{array}{c}-0.0010 * * * \\
(3.47)\end{array}$ & $\begin{array}{c}-0.0011 * \\
(1.91)\end{array}$ & $\begin{array}{c}-0.0007^{* *} \\
(2.05)\end{array}$ \\
\hline College & $\begin{array}{l}0.1153 \text { *** } \\
(3.22)\end{array}$ & $\begin{array}{l}0.0524 * * \\
(2.23)\end{array}$ & $\begin{array}{l}0.1564 * * * \\
(4.17)\end{array}$ & $\begin{array}{c}0.0475 * \\
(1.82)\end{array}$ \\
\hline Lunch & $\begin{array}{c}-0.1365 * * * \\
(3.58)\end{array}$ & $\begin{array}{c}-0.1198 * * * \\
(4.19)\end{array}$ & $\begin{array}{c}-0.1836 * * * \\
(4.56)\end{array}$ & $\begin{array}{c}-0.0705 \text { *** } \\
(2.55)\end{array}$ \\
\hline Number of Observations & 607 & 607 & 607 & 607 \\
\hline R-squared & 0.55 & 0.56 & 0.66 & 0.33 \\
\hline
\end{tabular}

Note: Expenditure Per Pupil, Income, Average Teacher Salary, Density, and District Size in thousands.

Absolute value of heteroskedasticity-corrected t-statistics in parentheses.

* indicates significance at the $10 \%$ level, ** at $5 \%$ level and *** at the $1 \%$ level. 
Appendix Table 2

Marginal Effects Times Standard Deviations

\begin{tabular}{|c|c|c|c|c|c|c|}
\hline Variable & $\begin{array}{c}\text { Non-Spatial } \\
\text { Probit } \\
\text { (Table 2, } \\
\text { Column 1) }\end{array}$ & $\begin{array}{c}\text { SARP } \\
\text { Model } \\
\text { (Table 2, } \\
\text { Column 2) }\end{array}$ & $\begin{array}{l}\text { SDP Model } \\
\text { (Table 2, } \\
\text { Column 3) }\end{array}$ & $\begin{array}{l}\text { SDP Model } \\
\text { (Table 2, } \\
\text { Column 1) }\end{array}$ & $\begin{array}{l}\text { SDP Model } \\
\text { (Table 2, } \\
\text { Column 2) }\end{array}$ & $\begin{array}{l}\text { SDP Model } \\
\text { (Table 2, } \\
\text { Column 3) }\end{array}$ \\
\hline Constant & 0.000 & 0.000 & 0.000 & 0.000 & 0.000 & 0.000 \\
\hline Within 10 & -0.069 & -0.067 & -0.057 & & & \\
\hline Within 12 & & & & -0.006 & & \\
\hline Within 15 & & & & & -0.008 & \\
\hline Herfindahl & & & & & & -0.010 \\
\hline Property Tax Price & 0.062 & 0.058 & 0.056 & 0.054 & 0.059 & 0.050 \\
\hline Income Tax Price & -0.122 & -0.120 & -0.044 & -0.099 & -0.095 & -0.050 \\
\hline$\%$ Renters & -0.002 & -0.004 & 0.030 & 0.033 & 0.031 & 0.024 \\
\hline City Tax Dummy & 0.060 & 0.054 & 0.055 & 0.053 & 0.069 & 0.055 \\
\hline$\%$ Senior Citizens & -0.014 & -0.019 & 0.003 & -0.008 & -0.002 & 0.000 \\
\hline$\%$ of Agricultural Property & 0.065 & 0.054 & 0.070 & 0.068 & 0.080 & 0.064 \\
\hline$\%$ of Mineral Property & -0.052 & -0.054 & -0.025 & -0.017 & -0.028 & -0.029 \\
\hline$\%$ of Business Property & -0.056 & -0.056 & -0.072 & -0.068 & -0.093 & -0.069 \\
\hline$\%$ of Rural Residents & 0.024 & 0.013 & 0.054 & 0.060 & 0.062 & 0.047 \\
\hline
\end{tabular}




\section{Appendix Table 3}

List of Countries

\begin{tabular}{|c|c|c|}
\hline Algeria & Guinea-Bissau² & Papau New Guinea \\
\hline Argentina & Haiti & Paraguay \\
\hline Australia & Honduras & Peru \\
\hline Austria & Hong Kong & Philippines \\
\hline Bangladesh & Hungary & Poland \\
\hline Belgium & India & Portugal \\
\hline Benin $^{1}$ & Indonesia & Romania $^{2}$ \\
\hline Bolivia & Iran & Rwanda $^{1}$ \\
\hline Botswana & Ireland & Senegal \\
\hline Brazil & Israel & Sierra Leone \\
\hline Bulgaria $^{2}$ & Italy & Singapore \\
\hline Burundi ${ }^{1}$ & Jamaica & South Africa \\
\hline Cameroon & Japan & South Korea \\
\hline Canada & Jordan & Spain \\
\hline Central African Republic ${ }^{1}$ & Kenya & Sri Lanka \\
\hline Chad $^{1}$ & Kuwait & Sweden \\
\hline Chile & Madagascar $^{2}$ & Switzerland \\
\hline China & Malawi & Syria \\
\hline Colombia & Malaysia & Taiwan \\
\hline Congo, Democratic Republic & Mali & Tanzania $^{2}$ \\
\hline Congo, Republic of the & Mauritius $^{1}$ & Thailand \\
\hline Costa Rica & Mexico & Togo \\
\hline Cote d'Ivoire ${ }^{2}$ & Morocco $^{2}$ & Trinidad \& Tobago \\
\hline Denmark & Myanmar & Tunisia \\
\hline Dominican Rep. & Namibia $^{2}$ & Turkey \\
\hline Ecuador & Nepal $^{1}$ & Uganda \\
\hline Egypt & Netherlands & United Arab Emirates ${ }^{2}$ \\
\hline El Salvador & New Zealand & United Kingdom \\
\hline Finland & Nicaragua & United States \\
\hline France & Niger & Uruguay \\
\hline Gabon $^{2}$ & Nigeria $^{2}$ & Venezuela \\
\hline Germany & Norway & Zambia \\
\hline Ghana & $\mathrm{Oman}^{2}$ & Zimbabwe \\
\hline Greece & Pakistan & \\
\hline Guatemala & Panama & \\
\hline
\end{tabular}




\section{Joshua C. Hall}

\section{Positions}

2004-2007 Graduate Student in Economics, West Virginia University

2004-2007

2006-2007

2004-2005

2001-2004

2000-2004

1999-2000

Dan Searle Humane Studies Fellow

Ken and Randy Kendrick Fellow

H.B. Earhart Fellow

Lecturer, Capital University

Director of Research, Buckeye Institute

Economist, Joint Economic Committee of Congress

\section{Education}

1997-1999

M.A. in Economics, Ohio University

1994-1997

B.B.A. in Business Economics, Ohio University

\section{Books, Edited}

Toward A Free and Prosperous Ohio (Columbus, OH: The Buckeye Institute, 2004).

\section{Articles in Refereed Journals}

"From ABBA to Zeppelin, Led: Using Music to teach Economics," Journal of Economic Education, forthcoming.

"Local School Finance and Productive Efficiency: Evidence from Ohio," Atlantic Economic Journal, forthcoming.

"Good for the Goose, Bad for the Gander: International Labor Standards and Comparative Development," with Peter T. Leeson, Journal of Labor Research, forthcoming.

"Using Music to Teach Microeconomics," with Robert A. Lawson, Perspectives on Economic Education Research, forthcoming.

"Can You Hear Me In The Back? Using Walkie Talkies to Improve Large Section Instruction," with Russell S. Sobel, Journal of Private Enterprise, forthcoming.

"The Effect of Judicial Selection Processes on Judicial Quality: The Role of Partisan Politics," with Russell S. Sobel, Cato Journal vol. 27, no. 1 (Winter 2007): 67-82.

"Do Gas Stations Raise the Price of Gasoline on the Weekends or Holidays?" with Robert Lawson and Lauren Raymer, Atlantic Economic Journal (Anthology Section) vol. 35, no. 1 (March 2007): 119-120. 
"Fiscal Competition and Tax Instrument Choice: The Role of Income Inequality," Economics Bulletin vol. 8, no. 12 (2006): 1-8.

"The Dilemma of School Finance Reform," Journal of Social, Political, and Economic Studies vol. 31, no. 2 (Summer 2006): 175-190.

"Positive Externalities and Government Involvement in Education," Journal of Private Enterprise vol. 21, no. 2 (Spring 2006): 165-175.

"Homer Economicus: Using The Simpsons to Teach Economics," Journal of Private Enterprise vol. 20, no. 2 (Spring 2005): 165-176. [Winner of the 2005 "Best Educational Note" Award from the Association of Private Enterprise Education]

"The Impact of Private Schools on Public School Performance: Evidence from Ohio," with Richard K. Vedder, Journal of Economics and Politics vol. 16, no. 1 (2003-04): 7792.

"For Profit Schools Are Making A Comeback," with Richard K. Vedder, The Independent Review vol. 6, no. 4 (Spring 2002): 573-583.

"Private School Competition and Public School Teacher Salaries," with Richard K. Vedder, Journal of Labor Research vol. 21, no. 1 (Winter 2000): 161-168.

\section{Articles in Collected Volumes}

"The Economics of Government Housing Assistance for the Poor," with Matt Ryan in America's Housing Crisis: A Case of Government Failure, edited by Randall Holcombe and Benjamin Powell, forthcoming.

"Horace Mann," in Exploring American History, forthcoming.

"The Sources of Economic Growth," with Russell Sobel in Unleashing Capitalism: Why Prosperity Stops at the West Virginia State Line and How to Fix It, Russell Sobel (ed), Morgantown, WV: The Public Policy Foundation of West Virginia, (2007): 15-35.

"When It Comes to Taxes: Focus on Being Competitive," with Justin Ross in Unleashing Capitalism: Why Prosperity Stops at the West Virginia State Line and How to Fix It, Russell Sobel (ed), Morgantown, WV: The Public Policy Foundation of West Virginia, (2007): 69-79.

"Walter Williams" in American Conservatism: An Encyclopedia, edited by Bruce Frohnen, Jeffrey O. Nelson, and Jeremy Beer. Wilmington, DE: ISI Books, 2006: 924925.

"Paul Heyne," in American Conservatism: An Encyclopedia, edited by Bruce Frohnen, Jeffrey O. Nelson, and Jeremy Beer. Wilmington, DE: ISI Books, 2006: 385-386. 


\section{Monographs and Studies}

Public Policy and Entrepreneurship with Russell S. Sobel (Kansas City, MO: Center for Applied Economics, July 2006).

Should Ohio Limit Government Spending and Taxes? with Russell S. Sobel, Robert A. Lawson and Barry W. Poulson (Columbus, OH: The Buckeye Institute, January 2005).

Taxing Times: How California's Steep Income Tax Stifles Growth with Russell S. Sobel and Robert A. Lawson (San Francisco, CA: Pacific Research Institute, April 2004).

Effective, Efficient, Fair: Paying for Public Education in Texas with Richard K. Vedder (Austin, TX: Texas Public Policy Foundation, February 2004).

Five Steps to Fundamental Tax Reform: A Pro-Growth Blueprint with Samuel R. Staley (Columbus, OH: The Buckeye Institute, February 2004).

Income Tax Progressivity in Oklahoma: Hindering Economic Growth, Variating State Revenue with Russell S. Sobel and Robert A. Lawson (Oklahoma City, OK: Oklahoma Council of Public Affairs, December 2003).

Education Empowerment Zones: Revitalizing Ohio's Cities Through School Choice with Samuel R. Staley, Matthew S. Hisrich, and Aengus L. Barry (Columbus, OH: The Buckeye Institute, March 2003).

High School Graduation Rates in Ohio with Jay P. Greene (Columbus, OH: The Buckeye Institute, September 2002).

Empowering Parents: Using Ohio's Tax Code to Promote Choice and Innovation in Ohio's Public Schools with Tony Caporale (Columbus, OH: The Buckeye Institute, July 2002).

Fiscal Impact of Proposed Tax Credits for Contributions to Qualifying Nonprofit Scholarship Organizations under H.B. 202 (Columbus, OH: The Buckeye Institute, October 2001).

The Roots of Broadened Stock Ownership, Joint Economic Committee Report (Washington, DC: Government Printing Office, April 2000).

Investment in Education: Private and Public Returns, Joint Economic Committee Report (Washington, DC: Government Printing Office, January 2000).

Tax Expenditures: A Review and Analysis, Joint Economic Committee Report (Washington, DC: Government Printing Office, August 1999). 
Data Profile for the Scioto Conference Region with Sara Lichtin Boyd (Athens, OH: Institute for Local Government and Administration and Rural Development, October 1998).

\section{Book Reviews}

Helping People Help Themselves: From the World Bank to an Alternative Philosophy of Development Assistance, by David Ellerman, The University of Michigan Press, Ann Arbor, 2005. Forthcoming in Knowledge, Technology and Policy.

Knowledge Spillovers and Knowledge Management, edited by Charlie Karlssson, Per Flensburg, and Sven-Ake Hörte, Edward Elgar Publishing, Northampton, 2004. Forthcoming in Knowledge, Technology \& Policy.

Cities of Knowledge: Cold War Science and the Search for the Next Silicon Valley, by Margaret Pugh O'Mara, Princeton University Press, Princeton, 2005. Forthcoming in Knowledge, Technology \& Policy.

Law and Class in America: Trends since the Cold War, edited by Paul D. Carrington and Trina Jones, New York University Press, New York, 2006. Published in Law and Politics Book Review 16, no. 10 (October 2006): 775-779.

Writing Off Ideas: Taxation, Foundations, and Philanthropy in America, by Randall G. Holcombe, Transaction Publishers, New Brunswick, 2000. Published in Knowledge, Technology \& Policy 14, no. 3 (Fall 2001): 149-151.

\section{Honors and Awards}

2007 IHS Summer Graduate Research Fellowship

2006 Dan Searle Humane Studies Fellow

2006 Kendrick Fund Fellow

2006 The Vickers Doctoral Student Research Paper Award

2006 Jon Vilasuso Doctoral Student Publication Award

2006 Honorable Mention, Fraser Institute Student Essay Contest

2006 Kendrick Fund Summer Fellow

2005 Dan Searle Humane Studies Fellow

2005 Best Educational Note, Journal of Private Enterprise

2005 H.B. Earhart Fellow

2005 Kaufmann Foundation Entrepreneurship Seminar Tuition Award

2004 Dan Searle Humane Studies Fellow

2004 WVU Economics Department Research Assistantship

August 20, 2007 